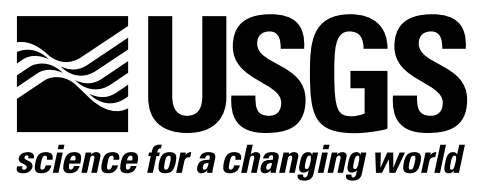

\title{
Role of Stranded Gas in Increasing Global Gas Supplies
}

By Emil D. Attanasi and Philip A. Freeman

Open-File Report 2013-1044

U.S. Department of the Interior

U.S. Geological Survey 


\title{
U.S. Department of the Interior SALLY JEWELL, Secretary
}

\section{U.S. Geological Survey Suzette M. Kimball, Acting Director}

\author{
U.S. Geological Survey, Reston, Virginia: 2013
}

For more information on the USGS - the Federal source for science about the Earth, its natural and living resources, natural hazards, and the environment, visit http://www.usgs.gov or call 1-888-ASK-USGS.

For an overview of USGS information products, including maps, imagery, and publications, visit http://www.usgs.gov/pubprod

To order this and other USGS information products, visit http://store.usgs.gov

Any use of trade, firm, or product names is for descriptive purposes only and does not imply endorsement by the U.S. Government.

Although this information product, for the most part, is in the public domain, it also may contain copyrighted materials as noted in the text. Permission to reproduce copyrighted items must be secured from the copyright owner.

Suggested citation:

Attanasi, E.D., and Freeman, P.A., 2013, Role of stranded gas in increasing global gas supplies: U.S. Geological Survey Open-File Report 2013-1044, 57 p., http://pubs.usgs.gov/of/2013/1044. (Available only online.) 


\section{Contents}

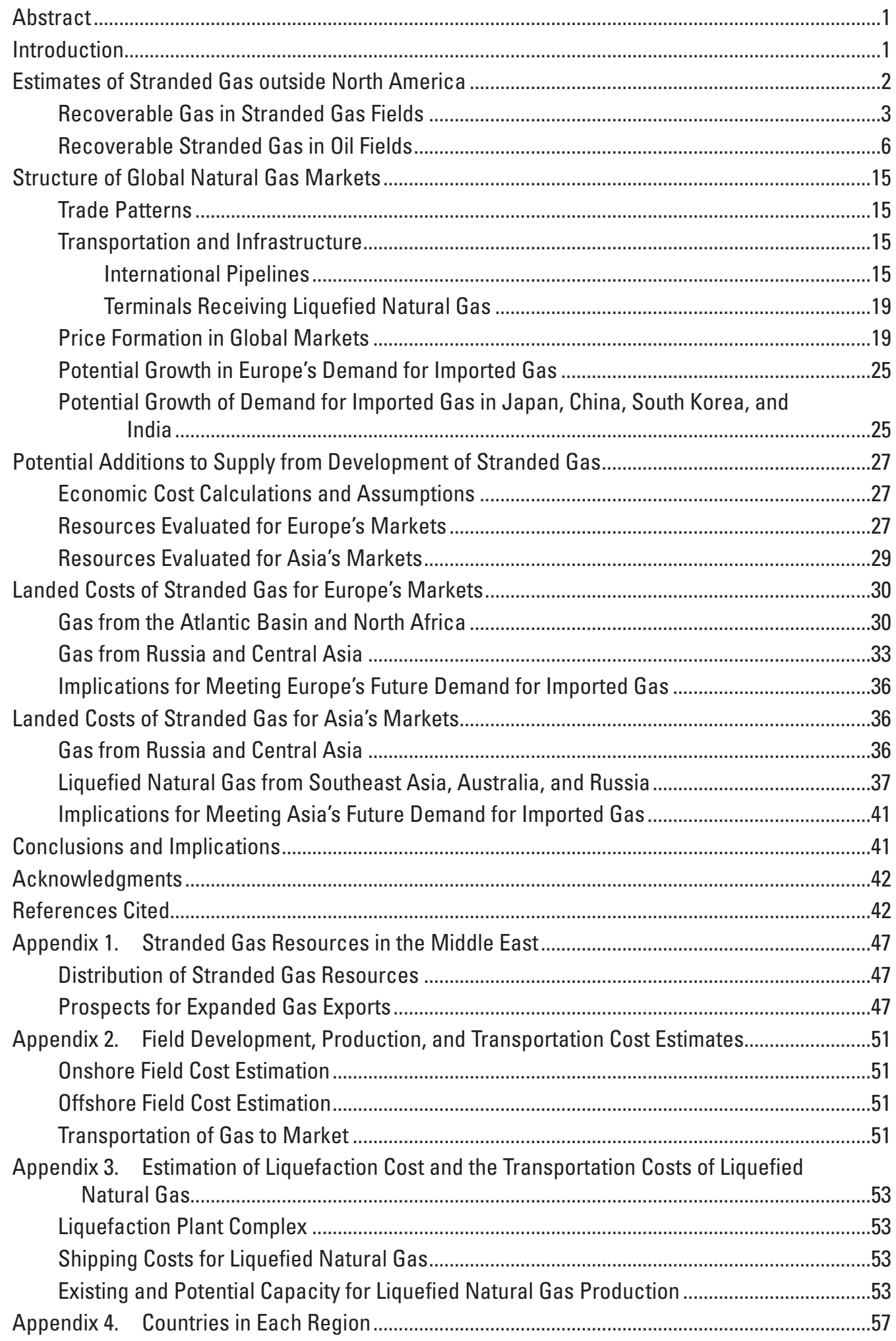




\section{Figures}

1. Bar graph showing volumes of remaining stranded gas in gas fields by region and by whether the field is onshore or offshore...

2. Map showing LNG liquefaction plants, a collection location, trans-Mediterranean pipeline inlets, clusters of stranded gas fields, and U.S. Geological Survey petroleum provinces in north Africa.

3. Map showing an LNG liquefaction plant, a collection location, clusters of stranded gas fields, and U.S. Geological Survey petroleum provinces in Nigeria.

4. Map showing U.S. Geological Survey petroleum provinces with clusters of stranded gas fields in central Asia and western Russia that were analyzed for delivery to markets in Europe

5. Map showing selected U.S. Geological Survey petroleum provinces in eastern Russia and central Asia with clusters of stranded gas fields analyzed for delivery to markets in Asia.

6. Map showing LNG liquefaction plants, clusters of stranded gas fields, and U.S. Geological Survey petroleum provinces in Indonesia, Malaysia, and Brunei in Southeast Asia

7. Map showing LNG liquefaction plants, clusters of stranded gas fields, and U.S. Geological Survey petroleum provinces in Australia.

8. Map showing LNG liquefaction plants, LNG regasification terminals, clusters of stranded gas fields, and U.S. Geological Survey petroleum provinces in the Middle East

9. Map showing the approximate location and routes of gas pipelines from Africa to Europe

10. Map showing clusters of stranded gas fields and approximate locations of existing and proposed pipelines for delivery to transshipment points en route to Europe.

11. Map showing clusters of stranded gas fields and a schematic of approximate location of existing and proposed pipelines for delivery to China and Vladivostok, Russia

12. Graph showing estimated costs by region of developing, producing, and transporting stranded gas destined for Europe's markets to coastal transshipment locations.

13. Graphs showing estimated costs by region of developing, producing, and transporting stranded gas destined for Europe's markets to the market point at the European Union border at Uzhhorod, Ukraine.

14. Graph showing estimated costs of developing, producing, and transporting stranded gas to Shanghai, China, from the West Siberian Basin, eastern Siberia, and central Asia (Turkmenistan, Uzbekistan, and Kazakhstan)

15. Graph showing estimated costs by region of developing, producing, and transporting stranded gas to coastal LNG plant locations 


\section{Tables}

1. Volumes of remaining recoverable stranded and other natural gas onshore and offshore in oil and gas fields by region outside North America.....

2. Distribution of gas by field size category for onshore and offshore stranded gas fields by regions.....

3. Volumes of stranded gas in oil fields having at least 1 TCF in original recoverable gas by region outside North America .

4. Volumes of gas in billions of cubic feet (BCF) marketed in North America, Europe,

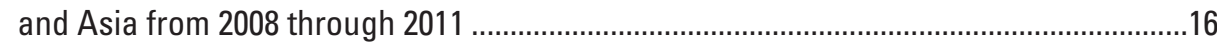

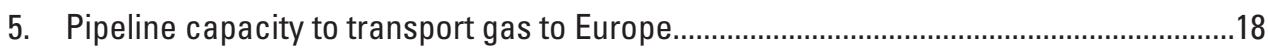

6. Pipeline capacity to transport gas to China and Singapore..............................................22

7. Location and capacity of terminals receiving liquefied natural gas (LNG) in Europe.

8. Location and capacity of liquefied natural gas (LNG) regasification terminals in Asia

9. Two demand scenarios for net natural gas imports by country showing historical imports and projections into the future for Japan, South Korea, China, and India.

10. Stranded gas resources evaluated for European and Asian markets ............................28

11. Estimated cost by country in north Africa and the Atlantic Basin for developing, producing, and transporting stranded gas destined for Europe's markets to coastal transshipment locations.

12. Estimated cost of liquefying and transporting natural gas as LNG from the source country to the destination regasification facility if the process gas cost were $\$ 3.00$ per thousand cubic feet.

13. Estimated cost of developing, producing, and transporting gas from stranded gas fields in Russia by petroleum province or producing area to the border of the European Union at Uzhhorod, Ukraine.

14. Estimated cost of developing, producing, and transporting gas from stranded gas fields in central Asia by country to the border of the European Union at Uzhhorod, Ukraine

15. Delivered threshold prices of the first tranche of gas as liquefied natural gas (LNG) from stranded gas fields in Australia, Malaysia, Indonesia, and Russia to four Asian markets

16. Estimated cost of developing, producing, and transporting gas to various operating and planned LNG complexes

A1-1. Volumes of remaining recoverable stranded natural gas onshore and offshore in Middle East oil and gas fields by country.

A1-2. Distribution of gas by field size category for stranded gas in gas fields in Iran, Iraq, Saudi Arabia, the United Arab Emirates, Oman, and Yemen............................................49

A2-1. Prototype model designs for onshore gas field development ........................................52

A2-2. Prototype model designs for offshore gas field development ......................................52

A3-1. Estimated costs of transporting liquefied natural gas (LNG) from LNG complex to destination regasification facility and market. 
A3-2. Existing LNG capacity outside North America …….....................................................55

A3-3. LNG capacity under construction accessible to Asian importers from Southeast Asia and Oceania.

A4-1. List of countries reporting stranded gas in gas fields by regions as used in figure 1 and tables $1,2,3$, and 4 .

\section{Conversion Factors}

\begin{tabular}{|c|c|c|}
\hline Multiply & $\mathrm{By}$ & To obtain \\
\hline \multicolumn{3}{|c|}{ Length } \\
\hline foot $(\mathrm{ft})$ & 0.3048 & meter $(\mathrm{m})$ \\
\hline mile (mi) & 1.609 & kilometer $(\mathrm{km})$ \\
\hline mile, nautical (nmi) & 1.852 & kilometer $(\mathrm{km})$ \\
\hline \multicolumn{3}{|c|}{ Volume } \\
\hline $\begin{array}{l}\text { barrel (bbl), (petroleum, } \\
1 \text { barrel=42 gallons) }\end{array}$ & 0.1590 & cubic meter $\left(\mathrm{m}^{3}\right)$ \\
\hline cubic foot $\left(\mathrm{ft}^{3}\right)$ & 0.02832 & cubic meter $\left(\mathrm{m}^{3}\right)$ \\
\hline cubic meter $\left(\mathrm{m}^{3}\right)$ & 35.31 & cubic foot $\left(\mathrm{ft}^{3}\right)$ \\
\hline \multicolumn{3}{|c|}{ Velocity } \\
\hline knot & 1.852 & kilometers per hour $(\mathrm{km} / \mathrm{h})$ \\
\hline knot & 0.5144 & meter per second $(\mathrm{m} / \mathrm{s})$ \\
\hline \multicolumn{3}{|c|}{ Energy } \\
\hline British thermal unit (Btu) & 1.055 & kilojoule $(\mathrm{kJ})$ \\
\hline
\end{tabular}




\section{Unit Abbreviations}

$\begin{array}{ll}\text { \$/MCF } & \text { dollars per thousand cubic feet in constant 2008 U.S. dollars } \\ \text { \$/MMBtu } & \text { dollars per million British thermal units in constant 2008 U.S. dollars } \\ \text { BCF } & \text { billions of cubic feet } \\ \text { BCF/D } & \text { billions of cubic feet per day } \\ \text { Btu } & \text { British thermal unit } \\ \mathrm{ft} & \text { feet } \\ \text { MCF } & \text { thousands of cubic feet } \\ \text { mi } & \text { mile } \\ \text { MMBtu } & \text { millions of British thermal units } \\ \text { MMCF/D } & \text { millions of cubic feet per day } \\ \text { MT } & \text { megaton or millions of metric tons } \\ \text { MTY } & \text { millions of metric tons per year } \\ \text { nmi } & \text { nautical mile } \\ \text { TCF } & \text { trillions of cubic feet } \\ \text { TCF } / Y & \text { trillions of cubic feet per year } \\ \text { USD/t } & \text { U.S. dollars per metric ton }\end{array}$

\section{Acronyms}

$\begin{array}{ll}\text { CNPC } & \text { China National Petroleum Corporation } \\ \text { EIA } & \text { U.S. Energy Information Administration } \\ \text { GIS } & \text { geographic information system } \\ \text { ICE } & \text { IntercontinentalExchange, Inc. } \\ \text { IEA } & \text { International Energy AJ HAF } \\ \text { IGU } & \text { International Gas Union } \\ \text { LNG } & \text { liquefied natural gas } \\ \text { NBP } & \text { National Balancing Point } \\ \text { NGL } & \text { natural gas liquids } \\ \text { NOC } & \text { national oil company } \\ \text { OPEC } & \text { Organization of the Petroleum Exporting Countries } \\ \text { TEPCO } & \text { Tokyo Electric Power Company } \\ \text { UAE } & \text { United Arab Emirates } \\ \text { UK } & \text { United Kingdom } \\ \text { USGS } & \text { U.S. Geological Survey }\end{array}$





\title{
Role of Stranded Gas in Increasing Global Gas Supplies
}

\author{
By Emil D. Attanasi and Philip A. Freeman
}

\section{Abstract}

This report synthesizes the findings of three regional studies in order to evaluate, at the global scale, the contribution that stranded gas resources can make to global natural gas supplies. Stranded gas, as defined for this study, is natural gas in discovered conventional gas and oil fields that is currently not commercially producible for either physical or economic reasons. The regional studies evaluated the cost of bringing the large volumes of undeveloped gas in stranded gas fields to selected markets. In particular, stranded gas fields of selected Atlantic Basin countries, north Africa, Russia, and central Asia are screened to determine whether the volumes are sufficient to meet Europe's increasing demand for gas imports. Stranded gas fields in Russia, central Asia, Southeast Asia, and Australia are also screened to estimate development, production, and transport costs and corresponding gas volumes that could be supplied to Asian markets in China, India, Japan, and South Korea.

The data and cost analysis presented here suggest that for the European market and the markets examined in Asia, the development of stranded gas provides a way to meet projected gas import demands for the 2020-to-2040 period. Although this is a reconnaissance-type appraisal, it is based on volumes of gas that are associated with individual identified fields. Individual field data were carefully examined. Some fields were not evaluated because current technology was insufficient or it appeared the gas was likely to be held off the export market. Most of the evaluated stranded gas can be produced and delivered to markets at costs comparable to historical prices. Moreover, the associated volumes of gas are sufficient to provide an interim supply while additional technologies are developed to unlock gas diffused in shale and hydrates or while countries transition to making a greater use of renewable energy sources.

\section{Introduction}

Recent studies (Massachusetts Institute of Technology, 2011; U.S. Energy Information Administration (EIA), 2011b) predict a bright future for the expansion of global natural gas supplies for the 25-year period starting with 2011 as a result of new technology used to extract gas in unconventional settings. In a recent article in Foreign Affairs, Deutch (2011), former director of the United States Central Intelligence Agency, outlined far-reaching domestic and foreign policy implications of the anticipated expansion of gas supplies. Over a long term, natural gas can be substituted for oil in some transportation uses. If global natural gas prices decline or if carbon emissions are constrained, gas-fired electrical power generation plants will likely replace coal- and oil-fired facilities.

Natural gas from unconventional sources was postulated to provide additional energy security benefits by weakening the Organization of the Petroleum Exporting Countries (OPEC), as natural gas can gradually be substituted for oil use either directly or with the conversion to vehicles powered by electricity (Deutch, 2011). The new supplies also reduce chances of a successful attempt to form a gas cartel based on the very uneven distribution of conventional natural gas resources. Deutch (2011) also articulated a vision of an integrated global gas market leading to the improved efficiency of all energy markets. Finally, the global benefits of replacing coal with natural gas in electrical power generation would be immense because traditional coal-fired electricity generation plants emit twice as much carbon dioxide as modern gas-fired plants when compared on a per-kilowatthour basis. Deutch (2011) argued that unconventional gas development could provide a reasonable transition to a future era of greater use of renewable resources that would bring meaningful reductions in carbon emissions.

This report synthesizes the findings of three regional studies (Attanasi and Freeman, 2011, 2012a,b) in order to evaluate, at the global scale, the contribution that stranded gas resources can make to global natural gas supplies. Stranded gas, as defined for this study, is natural gas in discovered conventional gas and oil fields that is currently not commercially producible for either physical or economic reasons. The regional studies evaluated the cost of bringing the large volumes of undeveloped gas in stranded gas fields to selected markets, and this study considers the global role that stranded gas might have in bridging the gap 
to increased reliance on production of unconventional gas resources, such as shale gas, gas in tight formations, coalbed methane (coal-seam gas), and gas from hydrates.

First, the geographical and size distribution of stranded gas fields is examined. The volumes of stranded gas in oil fields are also described and discussed, conditions for the development of this gas are enumerated, and commercial valuation is considered. Natural gas is sold into three regional gas markets: North America, Europe, and Asia. Earlier studies examined the future demand for the regional markets of Europe (Attanasi and Freeman, 2011, 2012a) and selected markets in Asia (Attanasi and Freeman, 2012b) and the potential contribution that stranded gas could make to supplies of these regional markets. A summary of these findings is presented in this global synthesis. The concluding section discusses the role that stranded gas resources might have in the transition to greater dependence on unconventional gas resources and renewable resources.

\section{Estimates of Stranded Gas outside North America}

Published natural gas reserves as of the beginning of 2008 for the world were estimated at 6,230 trillion cubic feet (TCF) (BP, 2012). This represents almost 55 years of global gas consumption at the current rates. This estimate is, however, not adequate for planning purposes because no internationally accepted standards were followed in the compilation of these reserve data. In the United States and Canada, volumes of gas identified as proved reserves are defined very narrowly because these estimates are used in the declaration of assets for publicly traded companies and as collateral for commercial loans. U.S. and Canadian estimates of proved reserves are entirely based on data from individual producing reservoirs and fields. ${ }^{1}$ For reserve estimates to be verifiable, the data should be tied to individual fields.

The stranded gas studies used the IHS International Petroleum Exploration and Production database (IHS Inc., 2009) as the basis for estimates of discovered resources at the field and reservoir level. Documentation states that IHS estimates of recoverable field volumes should be associated with a probability level of 0.50 , or, for short, p50 (Timothy R. Klett, U.S. Geological Survey, oral commun.). ${ }^{2}$ An estimate is said to be at the $\mathrm{p} 50$ level when the actual volume has a 50 -percent chance of being less than the estimate and a 50-percent chance of exceeding the estimate. The stranded gas studies discussed above presented cost estimates of gas from conventional gas fields ${ }^{3}$ that could contribute to international gas supplies. Fields having estimates of original recoverable gas of less than 48 billion cubic feet $(\mathrm{BCF})$ were excluded from this analysis because it was assumed that, in most cases, these fields were too small to be commercial targets for gas exports. Although in some instances, small fields may be commercially developed for local markets, in most cases, their production and transportation costs exceeded export market prices examined. Fields were classified into oil and gas fields on the basis of the ratio of estimated recoverable gas to estimated recoverable crude oil. ${ }^{4}$ Gas fields were initially classified as "producing - not stranded" if at least 5 percent of the estimated recoverable gas had been produced. The fields that remained were individually scrutinized to determine their status. Fields were classified as "producing" if reported production was consistent with early stages of commercial production. Remaining gas fields not classified as "producing" were subsequently considered stranded.

Several very large fields having only minimal development are considered stranded. These fields include Yoloten-Osman (Turkmenistan), Shah Deniz (Azerbaijan), Russkoye Yuzhnoye (Russia), and Bovanenkovskoye (Russia). In 2011, the recoverable gas estimate of the Yoloten-Osman field was increased to between 460 and 750 TCF (Gurt, 2011) after completion of this analysis. This is substantially greater than the IHS estimate (which was slightly less than 200 TCF) used in this analysis.

Gas volumes in oil fields were not stranded if the oil field was producing and at least 5 percent of the recoverable gas had been produced. The remaining gas in the oil field was considered stranded and potentially recoverable at a future time if not meeting these criteria. Some gas in oil fields may be re-injected to maintain oil field pressure to extend the field's production life and may not be reported as produced. Stranded gas in oil fields was treated differently than gas in gas fields. Even if this gas is re-injected, the gas may not be marketed for an indefinite period of time into the future.

\footnotetext{
${ }^{1}$ In particular, proved reserves are tied to individual proved reservoirs, which are proved by production, production tests, or core or log data to assure producibility. Areas of reservoirs can only be considered proved if they are delineated by drilling or if they adjoin proved areas where engineering and geologic data support an inference of producibility (U.S. Energy Information Administration, 2009c).
}

${ }^{2}$ Although IHS estimates are stated to be p50, no other information about their probability distribution is provided, and so the aggregation of the estimates was performed arithmetically.

${ }^{3} \mathrm{~A}$ conventional field is a discrete accumulation or set of accumulations that are bounded by a downdip water contact (U.S. Geological Survey World Energy Assessment Team, 2000); hydrocarbons in liquid or gaseous forms are extracted from the field.

${ }^{4} \mathrm{~A}$ field is classified as a gas field if its gas-to-oil ratio is at least 20,000 cubic feet of gas to 1 barrel of oil (U.S. Geological Survey World Energy Assessment Team, 2000). 


\section{Recoverable Gas in Stranded Gas Fields}

Table $1^{5}$ shows that for the world outside North America, the estimated stranded gas in gas fields totals 2,612 TCF, while remaining gas in producing gas fields is 2,854 TCF. Figure 1 shows the stranded gas data as a bar chart that delineates onshore and offshore resource volumes in gas fields. The leading regions for stranded gas in gas fields are Russia with 33 percent; Southeast Asia and Oceania, 17 percent; the Middle East, 12 percent; and central Asia, 12 percent. Overall, about 60 percent of the 2,612 TCF is in onshore stranded gas fields, and the remainder is offshore. However, 87 percent of the stranded gas of Southeast Asia and Oceania is offshore, and for Europe, 70 percent of the gas in stranded fields is offshore. Stranded gas volumes reflect the degree an area has been explored, the gas endowment, and the maturity of the area's transportation infrastructure.

Table 2 shows the field size distributions of the stranded gas fields by regions, including the Middle East. Field size distributions for Europe, south Asia, and east Asia are not shown because these regions are all major importers of gas, and so their stranded gas will not be exported outside of their regions. More detailed descriptions of the stranded gas field size distributions by country for the major supply regions outside the Middle East are presented in Attanasi and Freeman (2010, 2012a,b). Appendix 1 discusses the gas in the stranded gas fields of the Middle East, and its table A1-2 provides the stranded gas field size distributions for those countries in the Middle East with at least 10 TCF in stranded gas. In table 2, the columns show the number of fields in each size class, the cumulative percentage of fields starting from the largest to the smallest size fields, the volume of gas contained in each size class, and the cumulative percentage of the total region's gas volume from the largest to the smallest size fields. In most regions, gas is unevenly distributed by size category. Field sizes are important because, to a degree, gas extraction exhibits technical economies of scale; unit extraction costs are inversely related to field size. For this study, a field with at least 6 TCF of recoverable gas is significant in size ( $\sim 1$ billion barrels of oil). Data in table 2 show by region the share of gas in significant gas fields. For Africa, it is 4.7 percent; Southeast Asia and Oceania, 34 percent; South America, 38 percent; the Middle East, 54 percent; central Asia, 81 percent; and Russia, 82 percent.

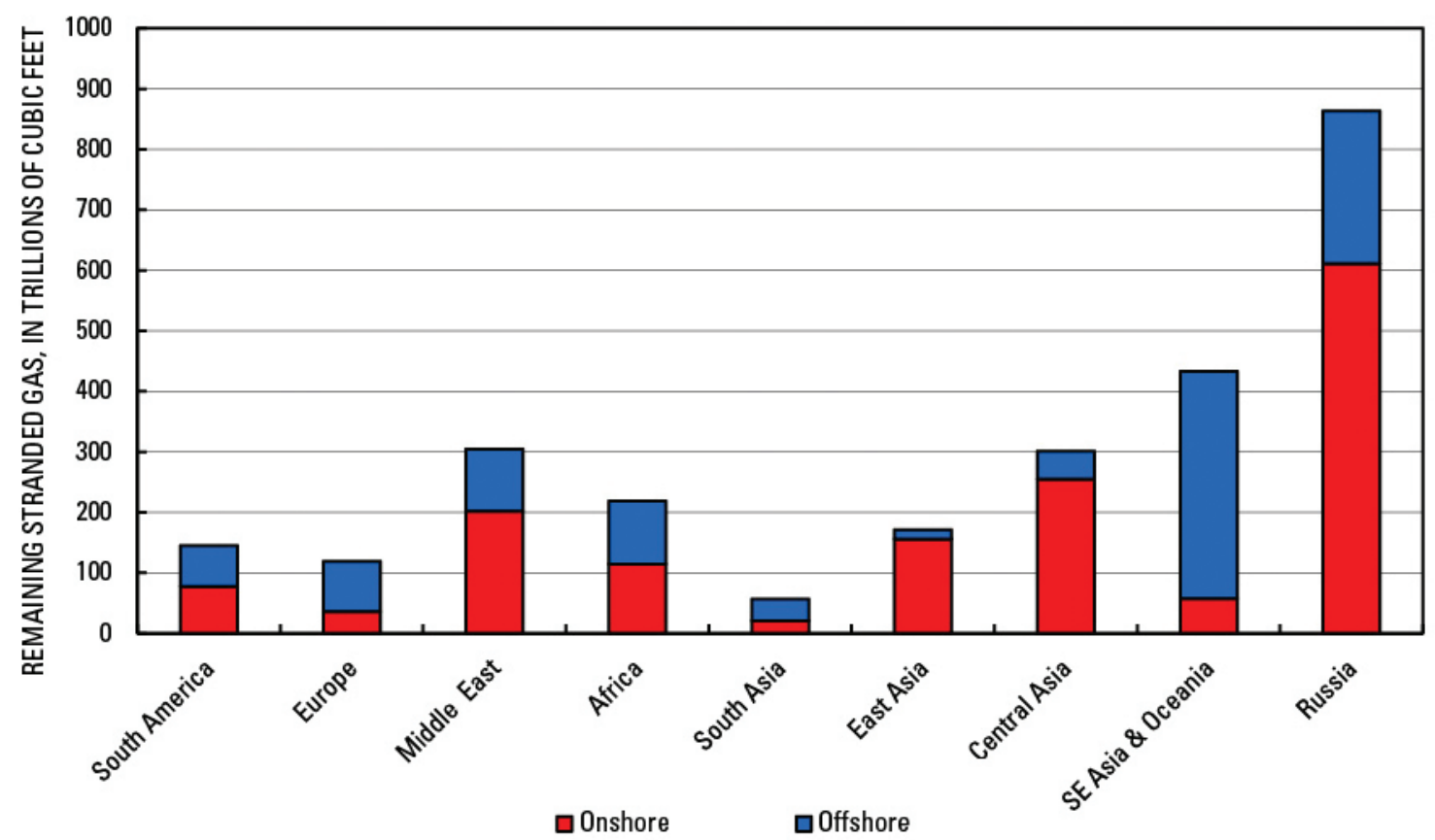

Figure 1. Bar graph showing volumes of remaining stranded gas in gas fields by region and by whether the field is onshore or offshore. Volumes plotted here are in table 1. Field data through the end of 2008 are from IHS Inc. (2009). Countries are listed by region in appendix 4 in table A4-1.

\footnotetext{
${ }^{5}$ South America includes stranded gas in fields in the Caribbean and Central America except Mexico; south Asia is Afghanistan, Bangladesh, India, and Pakistan; east Asia is China, Japan, South Korea, and Taiwan; central Asia is Azerbaijan, Georgia, Kazakhstan, Kyrgyzstan, Tajikistan, Turkmenistan, and Uzbekistan; Southeast Asia and Oceania are Australia, Brunei, Burma, Cambodia, Indonesia, Malaysia, New Caledonia, New Zealand, Papua New Guinea, Philippines, Thailand, and Vietnam. Please see table A4-1 in appendix 4 for a country listing for Europe, South America, the Middle East, and Africa. Russia is discussed separately from regional groups for Europe and Asia.
} 
Table 1. Volumes of remaining recoverable stranded and other natural gas onshore and offshore in oil and gas fields by region outside North America.

[Gas volumes are in trillions of cubic feet (TCF). Countries are listed by region in appendix 4 in table A4-1. Field data through the end of 2008 are from IHS Inc. (2009). Numbers may not add up due to rounding]

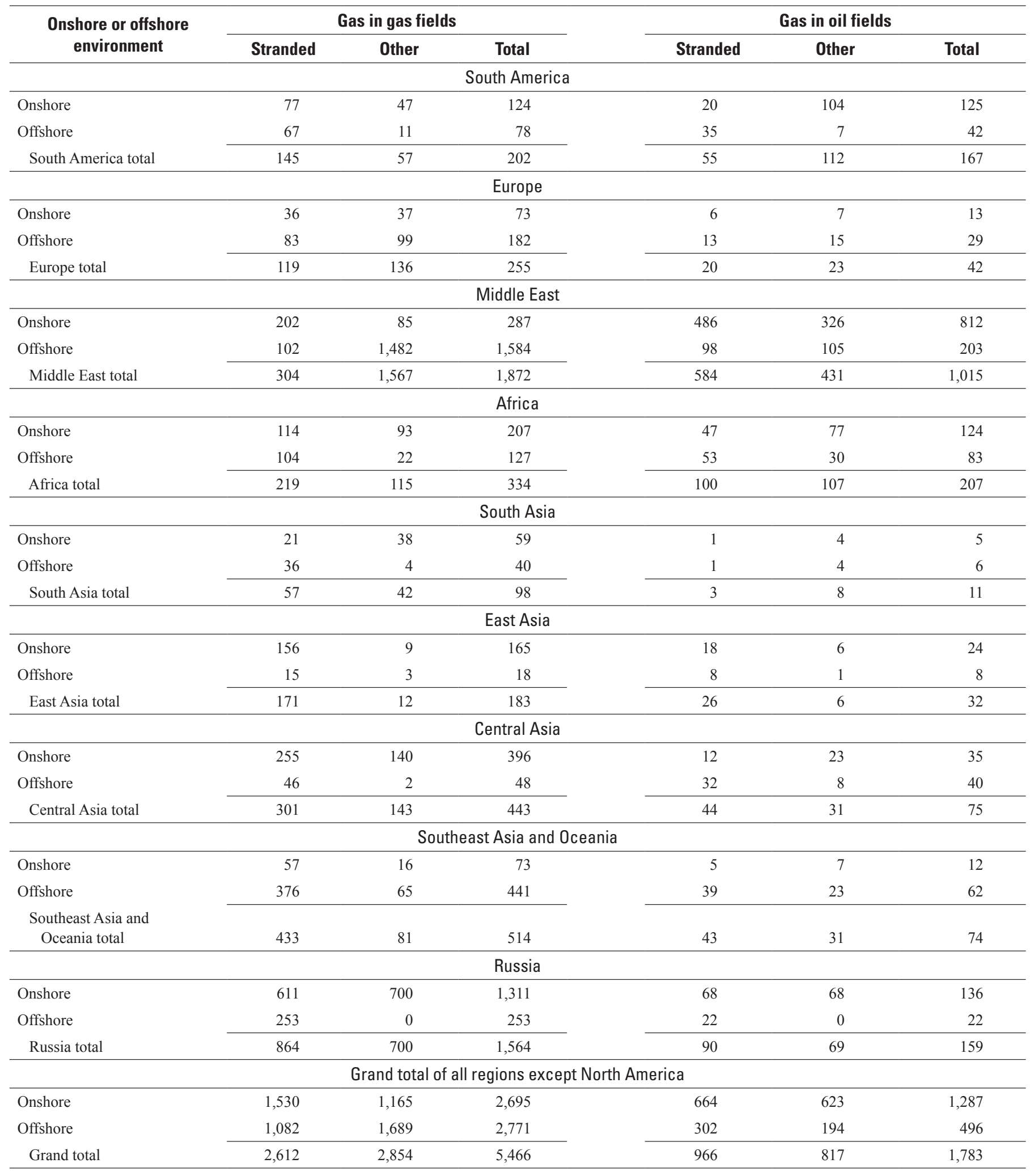


Table 2. Distribution of gas by field size category for onshore and offshore stranded gas fields by regions.

[Field data through the end of 2008 are from IHS Inc. (2009). Regional totals here differ slightly from those in table 1 because the minimum field size in this table is 0.048 TCF. Stranded gas in regions shown has export potential. TCF, trillions of cubic feet. Numbers may not add up due to rounding]

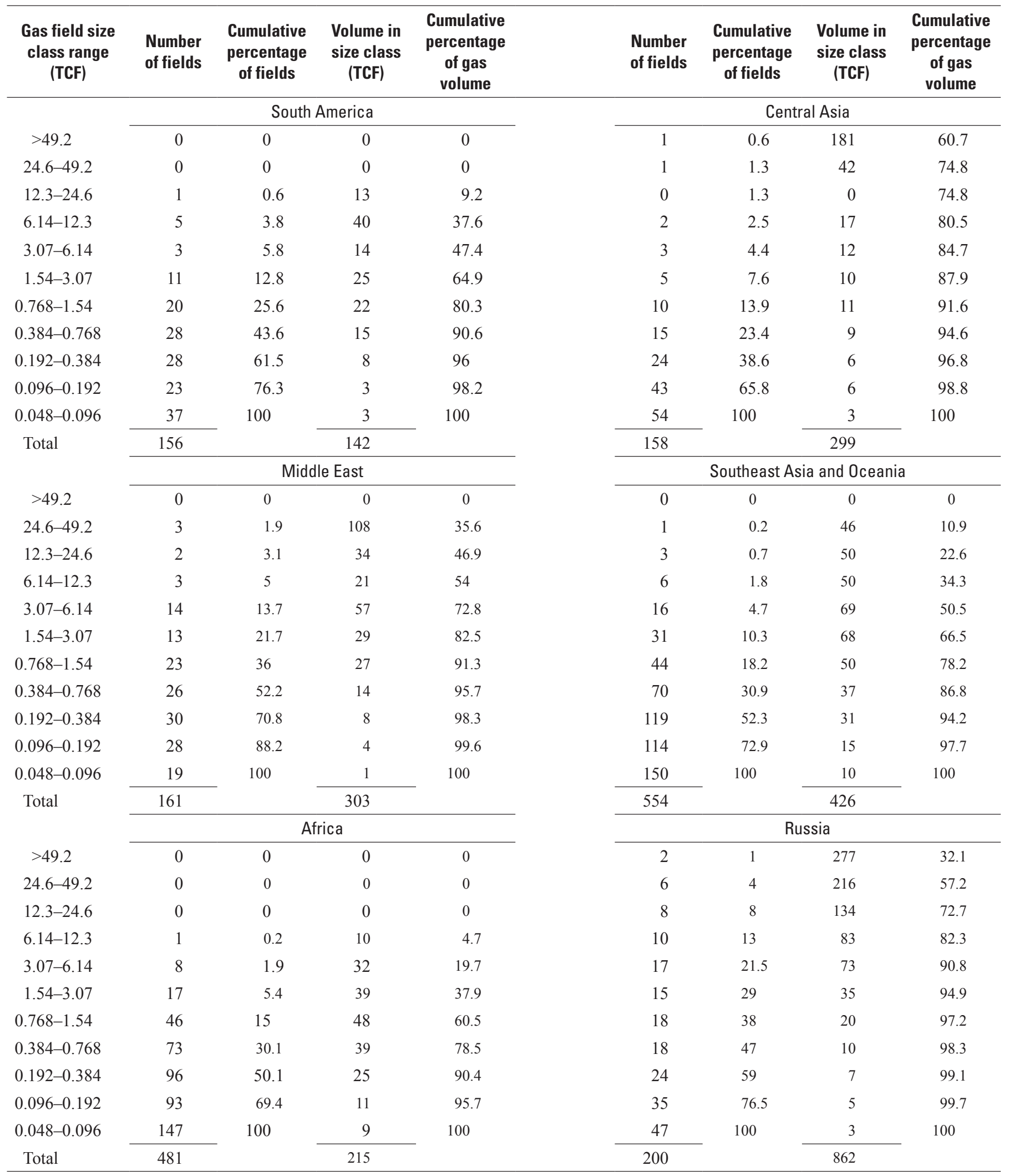


Figures 2 through 8 show the locations of clusters of stranded gas accumulations. Clusters of stranded gas fields are commonly in remote areas that tend to require large investments to develop, including facilities and infrastructure for gas production. The stranded fields also require large investments in infrastructure to transport gas to markets. Field volumes and costs for stranded gas clusters shown in north Africa (fig. 2) and Nigeria (fig. 3) are presented in Attanasi and Freeman (2010). Similarly, the costs of developing and transporting the stranded gas from fields in central Asia and western Russia (fig. 4) to markets in continental Europe are presented in Attanasi and Freeman (2012a). The costs of developing stranded gas for markets in Asia from the field clusters in eastern Russia and central Asia (fig. 5), Southeast Asia (fig. 6), and Australia (fig. 7) are presented in Attanasi and Freeman (2012b). A description of the stranded gas clusters shown in figure 8, representing the Middle East, is provided in appendix 1, along with a brief discussion of the development of natural gas exports from that region.

To summarize, although stranded gas fields are widely distributed, the largest concentrations by gas volumes are in Russia, Southeast Asia and Oceania, the Middle East, and central Asia (fig. 1). Concentrations of the large fields are in even fewer areas: Russia, the Middle East, and central Asia (table 2). Large stranded gas accumulations are important because they will allow scale economies and support development of necessary infrastructure. Not all of the stranded gas in table 1 is available for export to world markets because some volumes have been reserved for domestic consumption by the individual countries or there are technical reasons why some stranded fields cannot be safely developed.

\section{Recoverable Stranded Gas in Oil Fields}

Table 1 shows 664 TCF of technically recoverable gas in onshore oil fields outside of North America and 302 TCF in offshore oil fields. There is no assurance that these volumes will be brought to markets because the gas is a byproduct of the development of these oil fields. Natural gas in oil accumulations may occur as dissolved gas or as a gas cap. Produced natural gas is commonly used as a fuel in oil field operations. Gas that is produced with the oil must be separated before the oil enters the oil sales pipeline. If there are sufficient volumes of gas and there is infrastructure to transport the gas to market, the excess gas can be sold as a byproduct of oil production. The recovered gas may also be re-injected into the oil-producing reservoir to offset the natural decline in reservoir pressure and to improve overall oil recovery. The disposition of the gas depends on the infrastructure, market conditions, and oil-production regulations. Gas purchasers who require high reliability of gas supply are sometimes reluctant to purchase associated gas because gas production is subject to the vagaries of the oil market.

For commercial recovery of the re-injected gas, there must be a sufficient volume of gas remaining in the reservoir at the end of the oil field's productive life to justify investments in field conversion and facilities to transport the gas to market. The original volume of gas in the reservoir will be reduced by losses in the gas recycling process and by the gas used for fuel during the commercial life of the oil field. Over a 20- to 30-year field life, the gas consumed for fuel can be substantial. At this time, the oil field data do not provide details about the disposition of gas in the oil fields.

If gas recovery is considered likely only from oil fields having an original recoverable stranded gas resource of at least 1 TCF, then this size cutoff reduces the total volume of 664 TCF (table 1) in onshore oil fields to 532 TCF (table 3). Similarly, for offshore fields, the total volume of 302 TCF reduces to 192 TCF. Table 3 shows the regional distribution of the volumes of stranded gas in oil fields that have at least 1 TCF of recoverable gas. The oil fields in the Middle East account for 439 TCF of the 532 TCF of stranded gas in onshore oil fields and 84 TCF of the 192 TCF of stranded gas in offshore fields. In the Middle East, the stranded associated gas is in oil fields that have not begun to produce and in producing oil fields where gas is re-injected to maintain reservoir pressure or where gas is used in enhanced oil recovery. Oil volumes in Middle East fields are large, as are the volumes of associated gas. However, the immediate gas markets are limited. The leading oil producers in the Middle East are members of OPEC. In these countries, oil production, as well as the byproduct gas production, is subject to changing OPEC quotas. The profitability of conversion of gas to LNG requires a constant gas production stream so that a high utilization of the LNG facilities is attained. Consequently, it is not likely these oil fields will provide significant supplements to gas export supplies. The gas from these fields could provide feedstock to large petrochemical complexes after the oil is sufficiently depleted so that the oil fields are "converted" to gas fields.

For large onshore oil fields that are already producing and re-injecting large volumes of gas, the conversion of oil fields to natural gas fields consists of construction or upgrading of the gas processing facilities and gas sales pipelines to a hub or LNG plant. For offshore fields, the conversion might follow the pattern established by Statoil's Statfjord field in the North Sea, where production platforms were modified, some additional wells were drilled, and new gas sales pipelines were constructed (Statoil, 2012). Although conversion of oil fields to gas fields is more complex for offshore fields, the Statfjord conversion demonstrates that such projects can be commercially successful. The required conversion investments are specific to each offshore field and its original oil development configuration. 

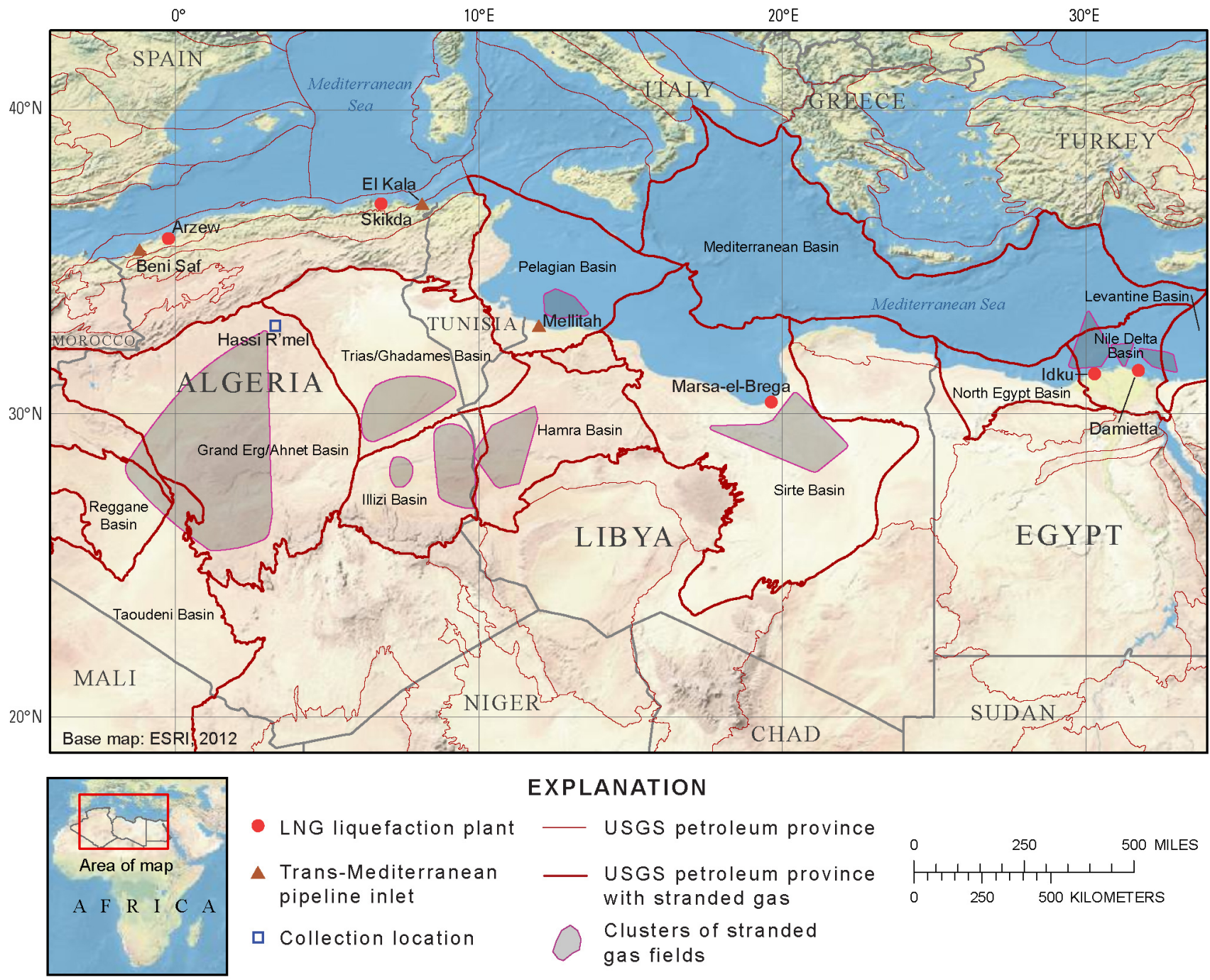

\section{EXPLANATION}

- LNG liquefaction plant USGS petroleum province

- Trans-Mediterranean pipeline inlet

USGS petroleum province with stranded gas

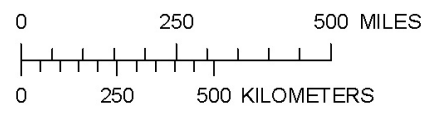

c Collection location

\section{Clusters of stranded} gas fields

Figure 2. Map showing LNG liquefaction plants, a collection location, trans-Mediterranean pipeline inlets, clusters of stranded gas fields, and U.S. Geological Survey (USGS) petroleum provinces (U.S. Geological Survey World Energy Assessment Team, 2000) in north Africa. LNG, liquefied natural gas. 

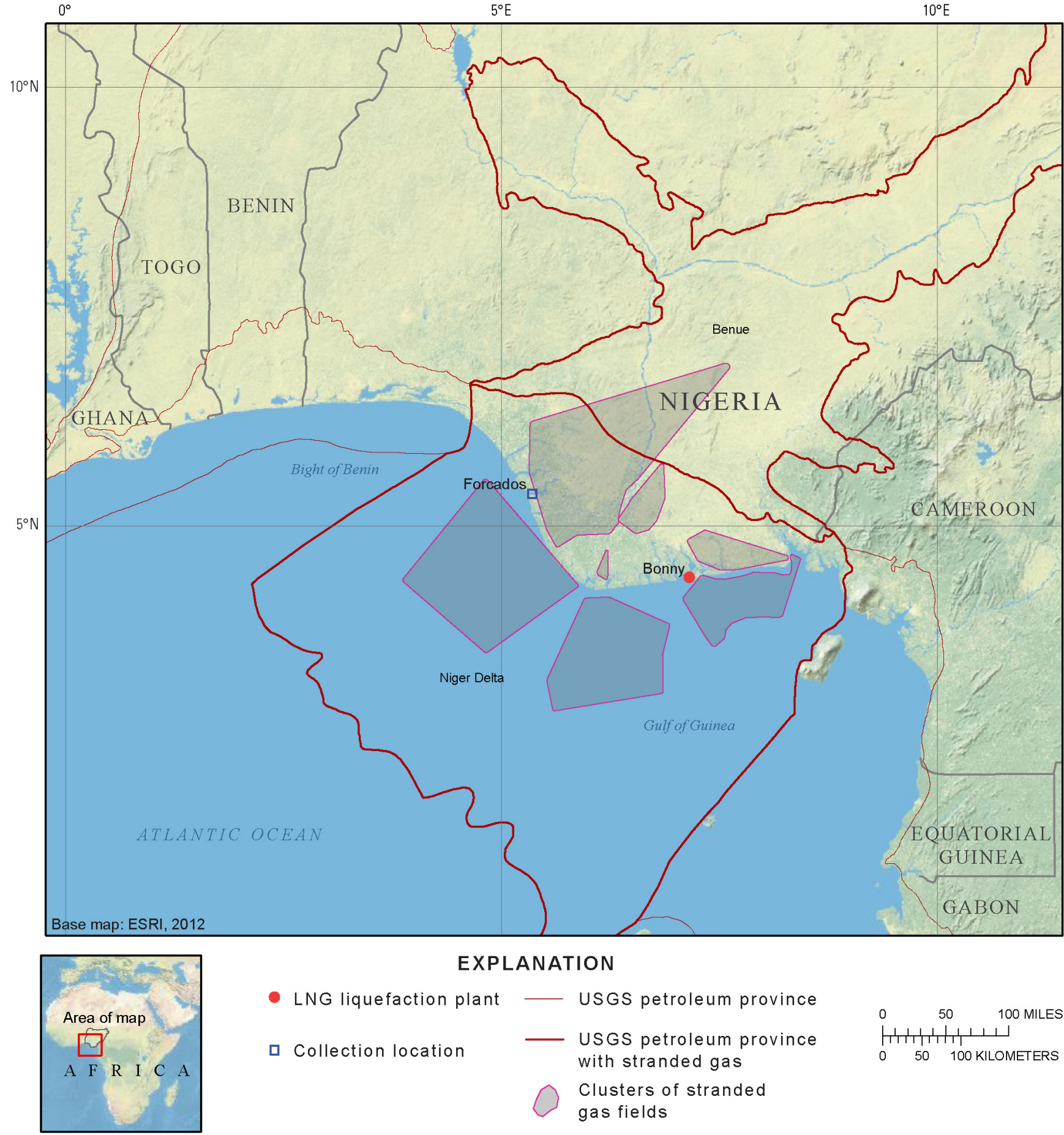

EXPLANATION

- LNG liquefaction plant USGS petroleum province

USGS petroleum province with stranded gas

O $50 \quad 100$ MILES

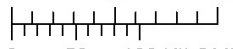

Collection location

Clusters of stranded gas fields

Figure 3. Map showing an LNG liquefaction plant, a collection location, clusters of stranded gas fields, and U.S. Geological Survey (USGS) petroleum provinces (U.S. Geological Survey World Energy Assessment Team, 2000) in Nigeria. LNG, liquefied natural gas. 


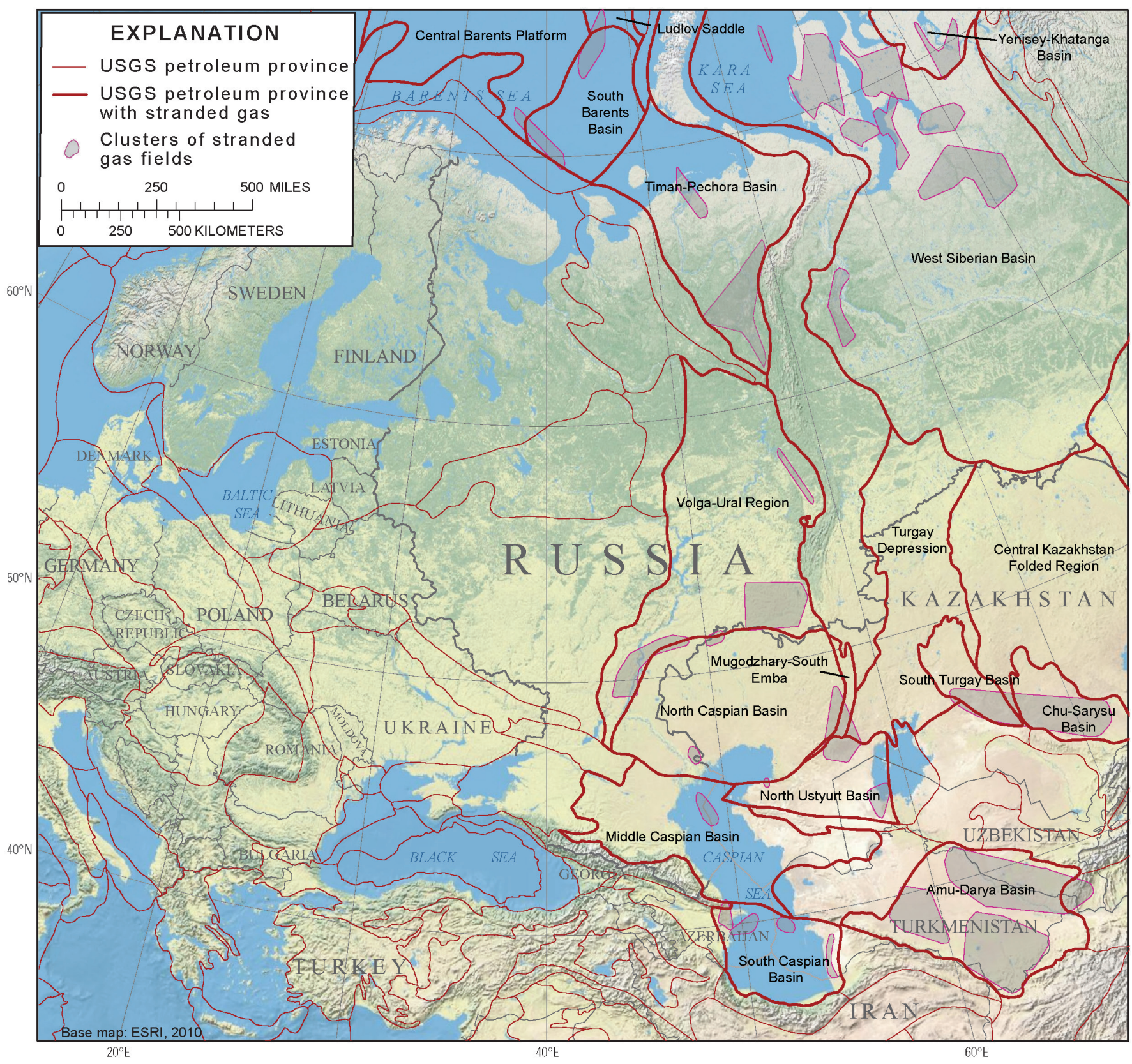

Figure 4. Map showing U.S. Geological Survey (USGS) petroleum provinces (U.S. Geological Survey World Energy Assessment Team, 2000) with clusters of stranded gas fields in central Asia and western Russia that were analyzed for delivery to markets in Europe. Figure modified from Attanasi and Freeman (2012a). 


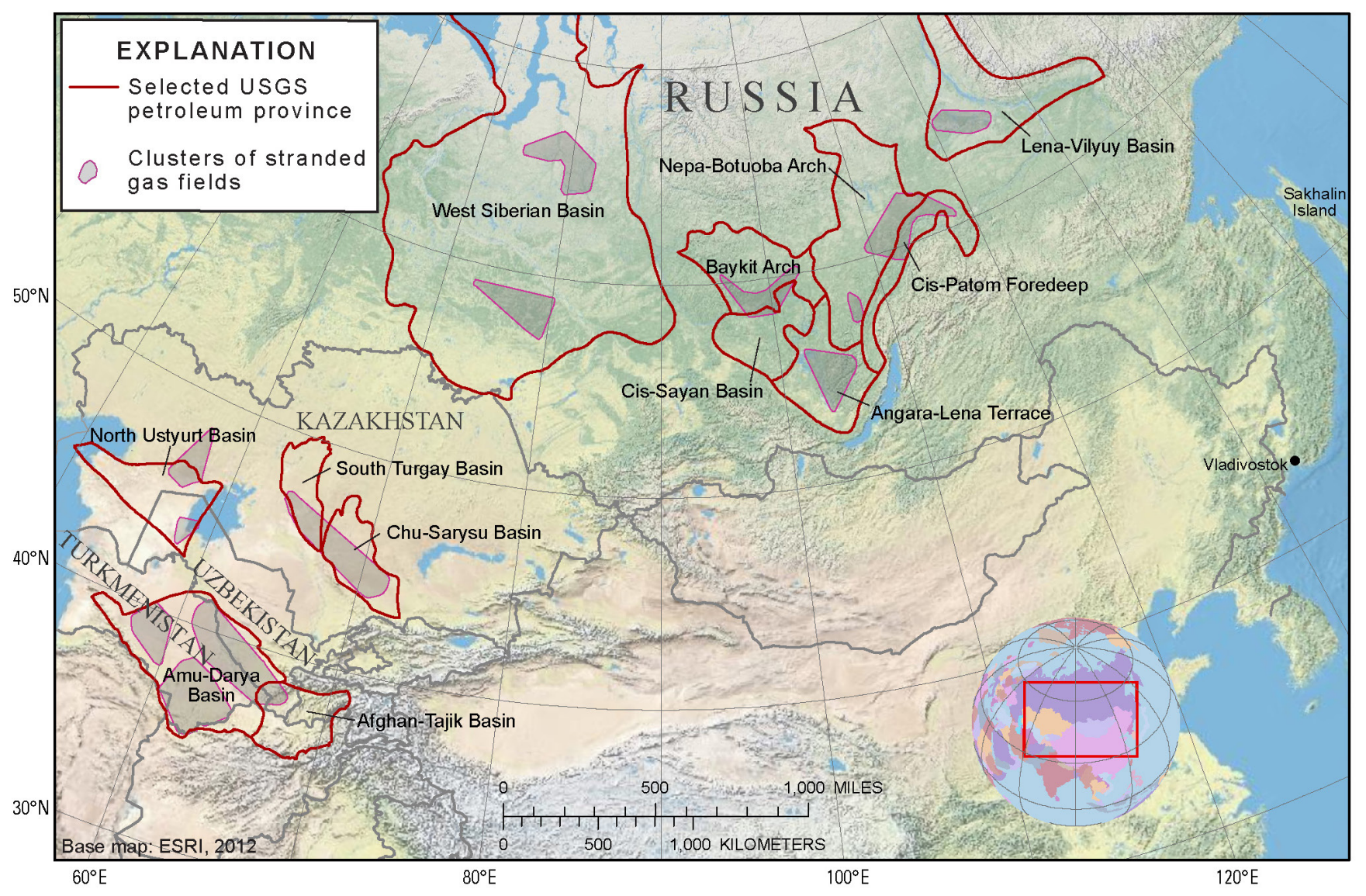

Figure 5. Map showing selected U.S. Geological Survey (USGS) petroleum provinces in eastern Russia and central Asia (U.S. Geological Survey World Energy Assessment Team, 2000) with clusters of stranded gas fields analyzed for delivery to markets in Asia. Figure modified from Attanasi and Freeman (2012b). 

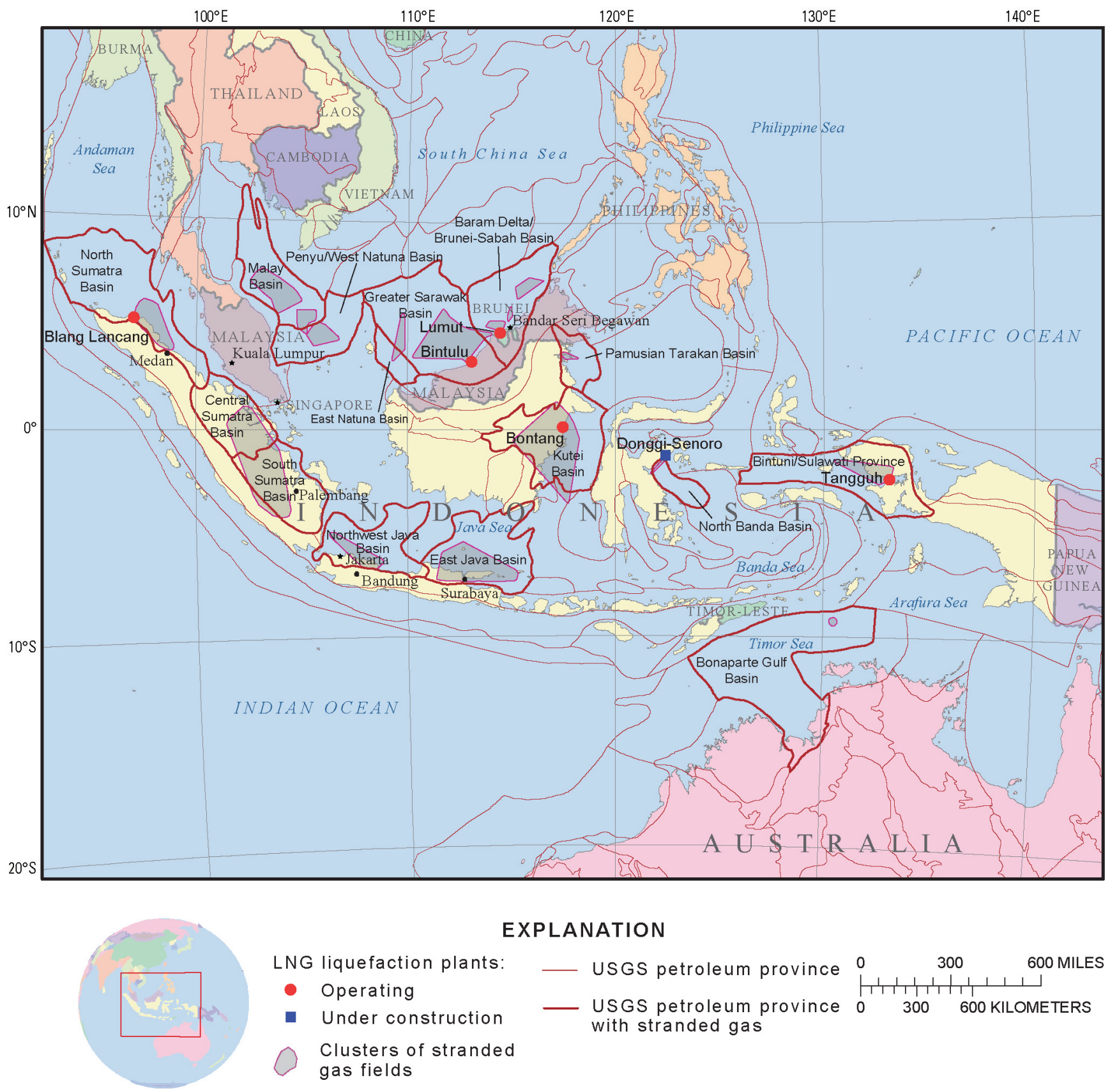

EXPLANATION

LNG liquefaction plants:

- Operating

- Under construction

USGS petroleum province

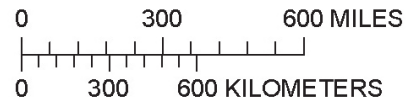

Clusters of stranded

USGS petroleum pro
with stranded gas

gas fields

Figure 6. Map showing LNG liquefaction plants, clusters of stranded gas fields, and U.S. Geological Survey (USGS) petroleum provinces (U.S. Geological Survey World Energy Assessment Team, 2000) in Indonesia, Malaysia, and Brunei in Southeast Asia. Figure modified from Attanasi and Freeman (2012b). LNG, liquefied natural gas. 

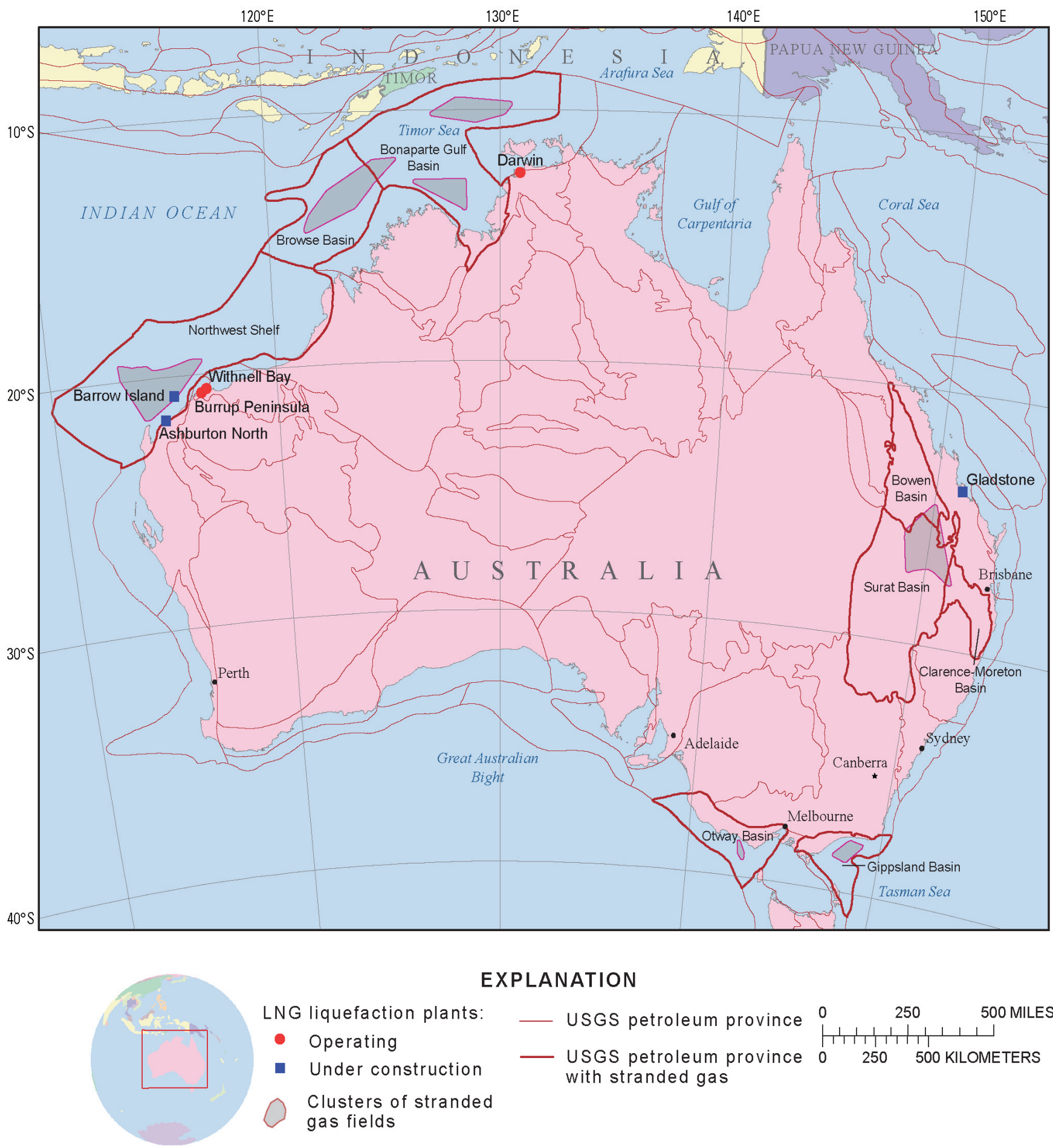

EXPLANATION

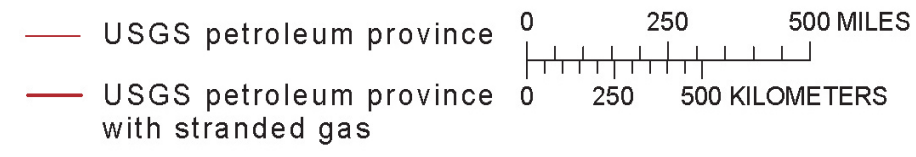
with stranded gas

Figure 7. Map showing LNG liquefaction plants, clusters of stranded gas fields, and U.S. Geological Survey (USGS) petroleum provinces (U.S. Geological Survey World Energy Assessment Team, 2000) in Australia. Figure modified from Attanasi and Freeman (2012b). LNG, liquefied natural gas. 


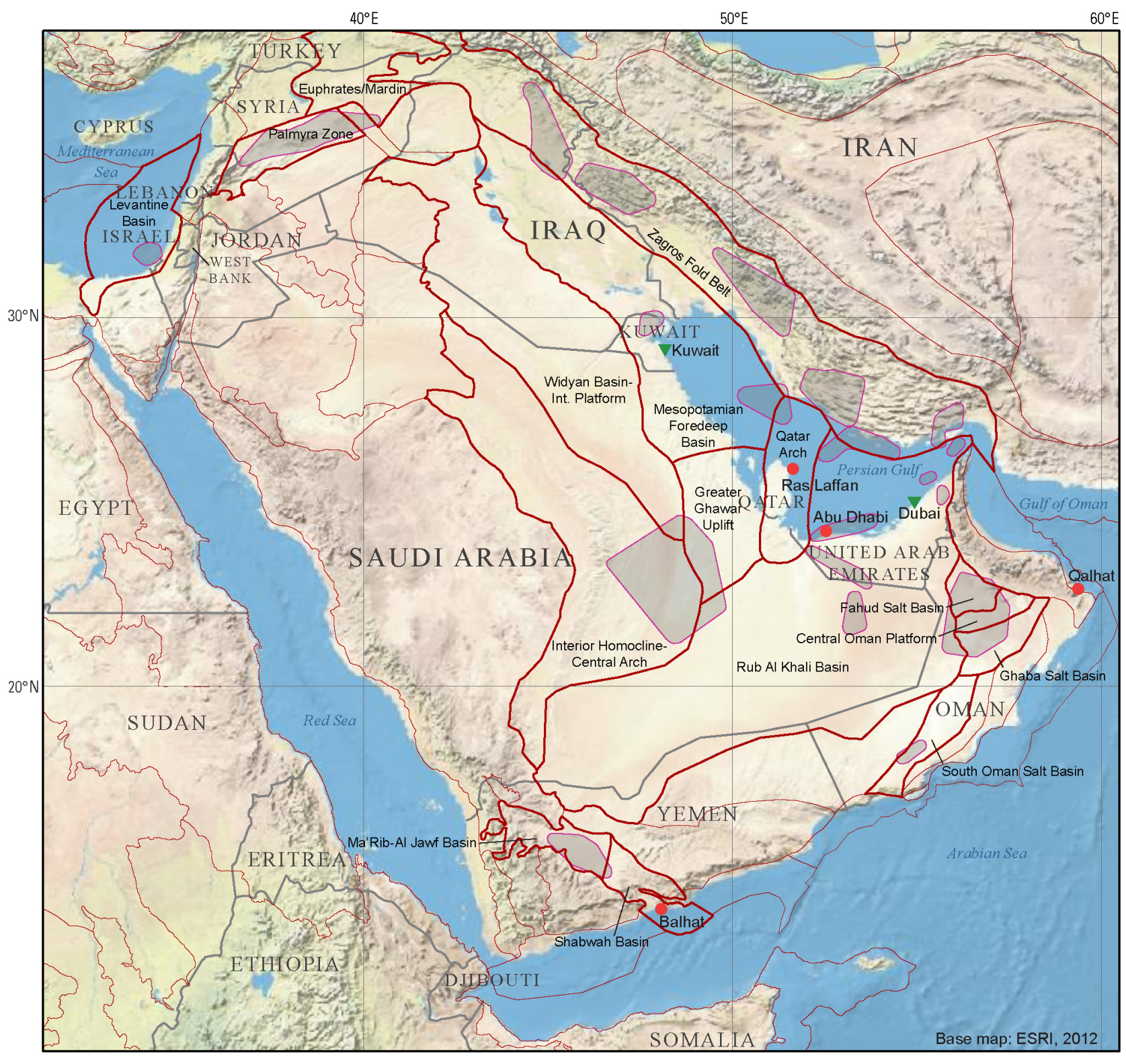

- LNG liquefaction plant EXPLANATION

$\checkmark$ LNG regasification terminal
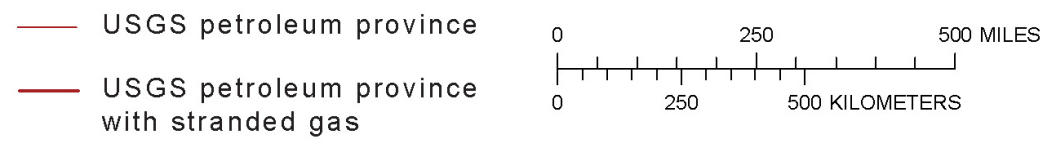

Clusters of stranded gas fields with stranded gas

Figure 8. Map showing LNG liquefaction plants, LNG regasification terminals, clusters of stranded gas fields, and U.S. Geological Survey (USGS) petroleum provinces (U.S. Geological Survey World Energy Assessment Team, 2000) in the Middle East. 


\section{Role of Stranded Gas in Increasing Global Gas Supplies}

Table 3. Volumes of stranded gas in oil fields having at least 1 TCF in original recoverable gas by region outside North America.

[Gas volumes are in trillions of cubic feet (TCF). Field data through the end of 2008 are from IHS Inc. (2009). South Asia is not in this table because it does not have any oil fields with at least $1 \mathrm{TCF}$ of gas that is classified as stranded gas. Numbers may not add up due to rounding]

\begin{tabular}{|c|c|c|}
\hline Onshore or offshore environment & Remaining gas & Original recoverable gas \\
\hline \multicolumn{3}{|c|}{ South America } \\
\hline Onshore & 11 & 12 \\
\hline Offshore & 26 & 26 \\
\hline South America total & 37 & 37 \\
\hline \multicolumn{3}{|c|}{ Europe } \\
\hline Onshore & 0 & 0 \\
\hline Offshore & 4 & 4 \\
\hline Europe total & 4 & 4 \\
\hline \multicolumn{3}{|c|}{ Middle East } \\
\hline Onshore & 439 & 446 \\
\hline Offshore & 84 & 84 \\
\hline Middle East total & 523 & 530 \\
\hline \multicolumn{3}{|c|}{ Africa } \\
\hline Onshore & 20 & 20 \\
\hline Offshore & 13 & 13 \\
\hline Africa total & 33 & 33 \\
\hline \multicolumn{3}{|c|}{ East Asia } \\
\hline Onshore & 2 & 2 \\
\hline Offshore & 4 & 4 \\
\hline East Asia total & 6 & 6 \\
\hline \multicolumn{3}{|c|}{ Central Asia } \\
\hline Onshore & 6 & 6 \\
\hline Offshore & 30 & 30 \\
\hline Central Asia total & 37 & 37 \\
\hline \multicolumn{3}{|c|}{ Southeast Asia and Oceania } \\
\hline Onshore & 1 & 1 \\
\hline Offshore & 12 & 13 \\
\hline Southeast Asia and Oceania total & 14 & 14 \\
\hline \multicolumn{3}{|c|}{ Russia } \\
\hline Onshore & 52 & 52 \\
\hline Offshore & 19 & 19 \\
\hline Russia total & 71 & 72 \\
\hline \multicolumn{3}{|c|}{ Grand total of all regions except North America } \\
\hline Onshore & 532 & 539 \\
\hline Offshore & 192 & 193 \\
\hline Grand total & 725 & 732 \\
\hline
\end{tabular}




\section{Structure of Global Natural Gas Markets}

\section{Trade Patterns}

From a global perspective, analysts commonly identify the three regional natural gas import markets as North America, Europe, and Asia (Siliverstovs and others, 2005; International Gas Union (IGU), 2011; Rogers, 2012). Table 4 shows the primary supply regions with stranded gas and their exports to the three global gas import markets. The transactions labeled for the European market do not include gas originating from or gas imported and consumed by Turkey, Belarus, Moldova, and Ukraine. Overall, the LNG supplied to the three markets grew by 43 percent over the period from 2008 to 2011, with the largest increase coming from the Middle East. Although this LNG capacity was developed for the North American market (Flower, 2008), exports were marketed principally to Europe and Asia. Asia's increase in LNG imports from 2010 to 2011 was driven by closure of all of Japan's nuclear facilities following the Tohoku earthquake (magnitude 9.0) in northern Honshu, Japan, and the related tsunami on March 11, 2011, that damaged the Fukushima Dai-ichi nuclear powerplant. In Europe, new LNG supplies replaced 10 to 12 percent of pipeline gas from Russia. Russian gas sales to Europe declined about 12 percent from 2008 to 2009 and remained at least 10 percent below 2008 levels for 2010 and 2011. In 2009, Russia began to supply LNG from the Sakhalin Island LNG plant (in far eastern Russia; see fig. 5), which was marketed entirely to Asia.

\section{Transportation and Infrastructure}

\section{International Pipelines}

The growth in LNG supplies and marketing has been a force in integrating world gas markets (Hayes, 2006a). However, in the process of liquefaction, about 15 percent of the inlet gas is commonly used to power the plant, and additional volumes are lost as the seagoing LNG tankers use the boiloff gas to fuel the ship. The capital and operating cost of the LNG plant and tankers, as well as the losses in gas, are part of the transportation cost of bringing the gas to markets. Natural gas is also transported internationally by pipelines. Such pipelines can traverse countries called transit countries that are not the ultimate market for the gas. Shipping gas by pipeline across transit countries is costly and can be very risky. Transit countries may demand 4 to 6 percent of the gross value of the pipeline gas as transit fees. Moreover, risks include thievery, disruptions due to instability inside the transit country, and potential political and contract conflicts between the transit country and the pipeline operators. All three of the global markets are served by pipelines and LNG supplies. The North American market in recent years has become nearly self-sufficient, and there also is the possibility it could become a net supplier to other markets.

The north African country of Algeria exports pipeline natural gas across the Mediterranean Sea to continental Europe by the Maghreb-Europe pipeline, the trans-Mediterranean pipeline, and the MEDGAZ pipeline (fig. 9). The GALSI (Gasdotto Algeria

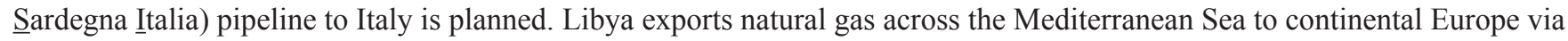
the GreenStream pipeline. Table 5 shows the installed capacity of these individual pipelines from Africa to Europe, totaling 5.9 billion cubic feet per day (BCF/D).

The natural gas export pipelines from Russia to Europe (fig. 10) are owned by Gazprom, the Russian Government-controlled integrated company that produces, transports, and markets gas. Gazprom owns the gas pipeline network inside Russia and has exclusive or monopoly rights to export gas from Russian territory (Sagers, 2007). Gazprom does not permit third-party access to its pipelines, and so historically it purchases and then resells gas from central Asian gas producers to European purchasers (Ericson, 2009). Gas originating in central Asia or Russia is transported to Germany by way of the Nord Stream system (underneath the Baltic Sea), to Poland through Belarus, or to Hungary through the Ukraine (fig. 10). In 2009, the Blue Steam pipeline delivered $0.95 \mathrm{BCF} / \mathrm{D}$ to Turkey (Gazprom, 2011a), which is well below its pipeline capacity of $1.5 \mathrm{BCF} / \mathrm{D}$. Table 5 presents a list of the operating pipelines from Russia to Europe shown in figure 10, along with origin, destination, and capacities. Table 5 also includes a list of proposed pipeline projects with planned capacities. Current capacity is 19.6 BCF/D for pipelines from Russia serving continental Europe exclusive of Turkey. The combined additional capacity of the proposed pipelines is 14.4 BCF/D. A more detailed discussion is presented in Attanasi and Freeman (2012a).

Asia includes the Far East as well as India and surrounding countries. The market is fragmented with a number of island nations. The earlier analysis (Attanasi and Freeman, 2012b) of imported gas into the Asian market focused on leading Asian importers of LNG: Japan, South Korea, China, and India (BP, 2012). China, which currently consumes about half of the world's coal produced annually, has announced plans to increase gas usage (Aibing, 2012). Although coal is commonly priced much cheaper than gas on a calorific basis, the capital costs involved in constructing new environmentally acceptable coal-fired electrical generation plants are substantially greater than such costs for new gas-fired generation plants, which can offset any direct fuel cost advantage. More than 400 million people, or one-third of India's population, do not have electrical service (Wolfram and others, 2012). Current projections of India's demand for electricity and fuels neglect the added demands that will occur as 
Table 4. Volumes of gas in billions of cubic feet (BCF) marketed in North America, Europe, and Asia from 2008 through 2011.

[Data are from BP (2009, 2010, 2011a, 2012). Numbers may not add up due to rounding]

\begin{tabular}{|c|c|c|c|c|c|c|c|c|c|c|c|c|}
\hline \multirow[b]{2}{*}{ Supply source } & \multicolumn{3}{|c|}{2011} & \multicolumn{3}{|c|}{2010} & \multicolumn{3}{|c|}{2009} & \multicolumn{3}{|c|}{2008} \\
\hline & $\begin{array}{c}\text { North } \\
\text { America }\end{array}$ & Europe* & Asia & $\begin{array}{c}\text { North } \\
\text { America }\end{array}$ & Europe* & Asia & $\begin{array}{c}\text { North } \\
\text { America }\end{array}$ & Europe* & Asia & $\begin{array}{c}\text { North } \\
\text { America }\end{array}$ & Europe* & Asia \\
\hline \multicolumn{13}{|c|}{ Liquefied natural gas (LNG) } \\
\hline North America & 0 & 10 & 48 & 0 & 12 & 30 & 0 & 0 & 30 & 0 & 0 & 34 \\
\hline South America & 214 & 205 & 72 & 274 & 235 & 86 & 270 & 264 & 66 & 309 & 178 & 70 \\
\hline Europe* & 15 & 108 & 52 & 30 & 98 & 17 & 33 & 79 & 3 & 20 & 43 & 15 \\
\hline Central Asia & 0 & 0 & 0 & 0 & 0 & 0 & 0 & 0 & 0 & 0 & 0 & 0 \\
\hline Russia & 0 & 0 & 508 & 0 & 0 & 473 & 0 & 0 & 219 & 0 & 0 & 0 \\
\hline Africa & 79 & 1,101 & 529 & 199 & 1,226 & 309 & 283 & 1,183 & 276 & 143 & 1,030 & 602 \\
\hline Middle East & 295 & 1,556 & 2,567 & 136 & 1,004 & 2,038 & 23 & 512 & 1,665 & 6 & 285 & 1,761 \\
\hline $\begin{array}{l}\text { Southeast Asia } \\
\text { and Oceania }\end{array}$ & 9 & 0 & 3,409 & 66 & 0 & 3,314 & 3 & 3 & 3,116 & 0 & 0 & 3,025 \\
\hline LNG total & 612 & 2,980 & 7,185 & 705 & 2,576 & 6,266 & 611 & 2,040 & 5,375 & 478 & 1,535 & 5,506 \\
\hline \multicolumn{13}{|c|}{ Pipeline gas } \\
\hline North America & 4,546 & 0 & 0 & 4,363 & 0 & 0 & 4,307 & 0 & 0 & 4,610 & 0 & 0 \\
\hline South America & 0 & 0 & 0 & 0 & 0 & 0 & 0 & 0 & 0 & 0 & 0 & 0 \\
\hline Europe* & 0 & 6,383 & 0 & 0 & 6,674 & 0 & 0 & 6,315 & 0 & 0 & 6,211 & 0 \\
\hline Central Asia & 0 & 0 & 503 & 0 & 0 & 125 & 0 & 65 & 0 & 0 & 344 & 0 \\
\hline Russia & 0 & 4,134 & 0 & 0 & 4,022 & 0 & 0 & 4,080 & 0 & 0 & 4,619 & 0 \\
\hline Africa & 0 & 1,242 & 0 & 0 & 1,558 & 0 & 0 & 1,383 & 0 & 0 & 1,610 & 0 \\
\hline Middle East & 0 & 0 & 0 & 0 & 0 & 0 & 0 & 0 & 0 & 0 & 0 & 0 \\
\hline $\begin{array}{l}\text { Southeast Asia } \\
\text { and Oceania }\end{array}$ & 0 & 0 & 1,022 & 0 & 0 & 1,052 & 0 & 0 & 676 & 0 & 0 & 594 \\
\hline $\begin{array}{c}\text { Pipeline gas } \\
\text { total }\end{array}$ & 4,546 & 11,758 & 1,525 & 4,363 & 12,254 & 1,177 & 4,307 & 11,843 & 676 & 4,610 & 12,784 & 594 \\
\hline \multicolumn{13}{|c|}{ LNG and pipeline gas } \\
\hline Grand total & 5,158 & 14,739 & 8,710 & 5,068 & 14,830 & 7,443 & 4,918 & 13,883 & 6,051 & 5,088 & 14,319 & 6,100 \\
\hline
\end{tabular}

*Europe does not include Turkey or the Former Soviet Republics of Belarus, Moldova, and Ukraine. 


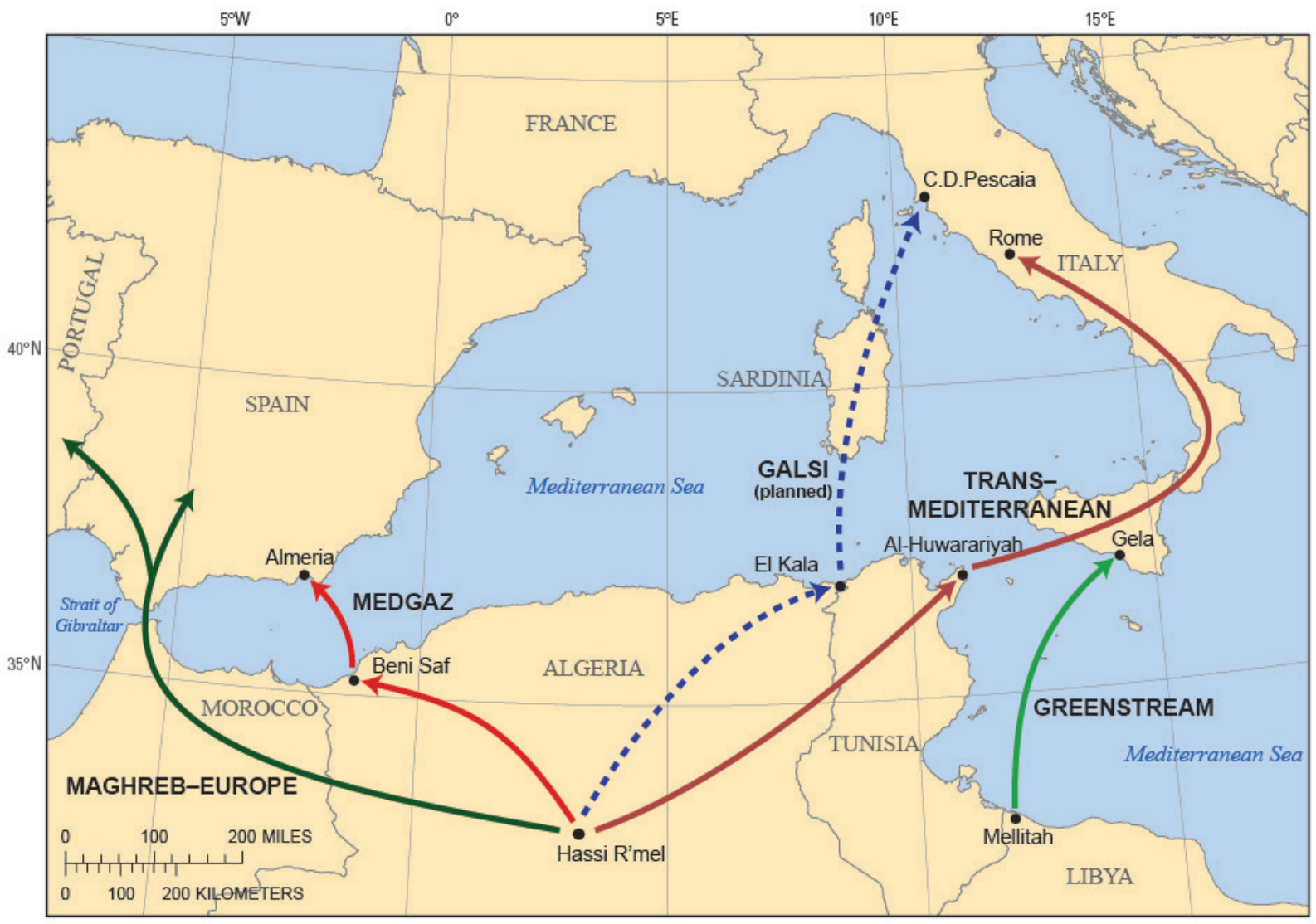

Figure 9. Map showing the approximate location and routes of gas pipelines from Africa to Europe. Figure modified from Attanasi and Freeman (2012a). 
Table 5. Pipeline capacity to transport gas to Europe.

[See footnotes for sources. BCF/D, billions of cubic feet per day. Numbers may not add up due to rounding]

\begin{tabular}{|c|c|c|c|}
\hline Pipeline & Origin & Destination & $\begin{array}{c}\text { Capacity } \\
\text { (BCF/D) }\end{array}$ \\
\hline \multicolumn{4}{|c|}{ From Africa to Europe (fig. 9) } \\
\hline Maghreb-Europe ${ }^{1}$ & Algeria & Spain and Portugal & 1.2 \\
\hline MEDGAZ $^{2}$ & Algeria & Spain & 0.8 \\
\hline \multicolumn{4}{|c|}{ From Russia to Germany and central Europe (fig. 10) } \\
\hline Yamal-Europe $^{4}$ & Russia & Belarus & 6.4 \\
\hline Northern Lights ${ }^{5}$ & Russia & Belarus & 4.4 \\
\hline Urengoy-Pomary-Uzhhorod ${ }^{6}$ & Russia & Ukraine & 3.1 \\
\hline \multicolumn{4}{|c|}{ From Russia and Azerbaijan to Turkey (fig. 10) } \\
\hline Blue Stream ${ }^{8}$ & Russia & Turkey & 1.5 \\
\hline South Caucasus ${ }^{9}$ & Azerbaijan & Turkey & 1.9 \\
\hline Total from Russia and Azerbaijan to Turkey & & & 3.5 \\
\hline \multicolumn{4}{|c|}{ Proposed (figs. 9 and 10) } \\
\hline Nord Stream, Phase $2^{7}$ & Russia & Germany & 2.7 \\
\hline South Stream ${ }^{10}$ & Russia & Bulgaria & 6.1 \\
\hline Trans-Anatolia ${ }^{11}$ & Azerbaijan & European gas system & 1.6 \\
\hline Nabucco $^{12}$ & Mid East & Austria & 3.0 \\
\hline
\end{tabular}

${ }^{1}$ Hayes, $2006 \mathrm{~b}$.

${ }^{2}$ MEDGAZ, 2009.

${ }^{3}$ Alexander's Oil and Gas Connections, 2004.

${ }^{4}$ IHS Inc., 2007.

${ }^{5}$ Pirani, 2009.

${ }^{6}$ For-UA, 2011.

${ }^{7}$ Nord Stream, 2011.

${ }^{8}$ Gazprom, 2011a.

${ }^{9} 1.9 \mathrm{BCF} / \mathrm{D}$ (BP, 2006) with planned additional compression stations; current capacity is $0.7 \mathrm{BCF} / \mathrm{D}$ (BP, 2011b).

${ }^{10}$ Gazprom, 2011b.

${ }^{11}$ Capacity expandable to $2.3 \mathrm{BCF} / \mathrm{D}$ (Socor, 2012).

${ }^{12}$ Pickl and Wirl, 2010.

${ }^{13}$ Algeria Ministry of Energy and MinIญ, 2009. 
a greater proportion of India's population is provided with electricity. Elsewhere in Asia, Bangladesh has 94 million, Indonesia has 81 million, Pakistan has 70 million, and Burma has 42 million people without electrical service (Wolfram and others, 2012). The potential future demand for Asian gas imports for electrical power generation goes well beyond that of Japan, South Korea, China, and India.

Figure 11 shows the route of the central Asia-China gas pipeline from Turkmenistan, through Uzbekistan, and to the Kazakhstan border with China. The First West-East pipeline was constructed years ago to bring domestic gas production from northwest China's Tarim Basin as gas production shifted to Xinjiang Province (Fridley, 2008). The Second West-East pipeline was constructed to bring the gas from the Kazakhstan border to Guangdong Province with a spur to Shanghai. A third WestEast pipeline will bring additional gas delivered to western China from central Asia east and to southern China. Table 6 lists the name, status, and capacity of each of the operating and hypothetical pipelines. The Turkmenistan-China pipeline has capacity of 2.9 BCF/D. In 2011, China imported about 1.4 BCF/D by pipeline and 1.6 BCF/D as LNG and consumed 12.6 BCF/D (BP, 2012). The additional pipelines from Russia listed in the table are hypothetical, and no official pipeline route has been put into the public domain. Table 6 also lists interregional pipelines from Malaysia and Indonesia to Singapore and from Burma to China.

\section{Terminals Receiving Liquefied Natural Gas}

Table 7 lists the terminals receiving LNG in the United Kingdom and continental Europe. The table shows that in 2011 they could receive $18.5 \mathrm{BCF} / \mathrm{D}$ in gas. Planned additions could increase the receiving capacity by about 5.6 BCF/D. The send-out capacity is a technical term and is the same as what is called here receiving capacity. It is the daily volume of gas that the terminal can send out to the local distribution systems. In 2011, Europe (including Turkey) imported 8.8 BCF/D as LNG (BP, 2012). It also imported 18.2 BCF/D of pipeline gas from outside of Europe. The United Kingdom (UK) accounts for about one-third of the send-out capacity. In 2011, the UK exported 1.5 BCF/D of gas to continental Europe. Additional regasification capacity could be added as floating facilities or as components to LNG tankers, allowing regasification directly. Natural gas markets in Europe and in the Far East that were examined commonly had large seasonal demand components. Although the capacity of the LNG regasification facilities appears to be more than adequate on an annual basis, the seasonal nature of demand means that in some months, users require 20 percent above the average monthly consumption.

Table 8 lists the regasification terminals in Asia by country along with the send-out capacity. In contrast to Europe, the Asian regional market is fragmented, and there are no import gas pipelines to Japan, South Korea, or India. Although Asia has 48 BCF/D of regasification capacity, its LNG imports averaged about 20 BCF/D in 2011. Japan and South Korea account for more than three-fourths of the capacity shown in the table. Demand for gas in both countries had very significant seasonal components.

\section{Price Formation in Global Markets}

The differences in natural gas price formation in the three regional markets reflect the historical development of the markets, as well as the relative endowment of conventional natural gas resources. For North America, the Henry Hub prices are representative of prevailing prices (International Gas Union (IGU), 2011). In both Canada and the United States, natural gas prices from the wellhead to the wholesale level have been deregulated for at least a decade. In the United States, several decades were needed for the process of deregulating wellhead prices, implementing third-party access for gas pipeline facilities, and establishing the hubs where prices reflect market conditions efficiently (Herbert and Kreil, 1996).

Natural gas prices in Europe are in transition. The National Balancing Point (NBP) is a virtual sales and exchange hub for wholesale natural gas transactions in the UK. It serves as the delivery and pricing reference point for the IntercontinentalExchange, Inc. (ICE), natural gas futures contract (International Gas Union, 2011). Alternatively, in continental Europe, natural gas prices have historically been determined by oil-product-indexed long-term contracts (IGU, 2004). When the giant Gronnigen gas field was developed in the Netherlands, producers priced the natural gas to be competitive with the refined oil products used in industrial processes and electrical power generation. On an energy-equivalent basis, natural gas is more difficult than petroleum products to transport, and demand growth is historically limited to that of a replacement fuel for oil and coal (IGU, 2004). Hence, gas demand growth depends on the rate that equipment using fuel other than natural gas will be replaced by equipment using natural gas.

Norway's, Russia's, and north Africa's gas suppliers adopted a similar policy of tying natural gas prices to prices of petroleum products and also of indexing gas price changes to changes in oil prices. Further, "take or pay" provisions were implemented to mitigate the supplier's risks associated with capital-intensive pipeline and LNG projects (Stern and Rogers, 2011). The European Union facilitated the development and integration of the continental Europe gas market with its evolving rules to eliminate transportation and trade barriers. 


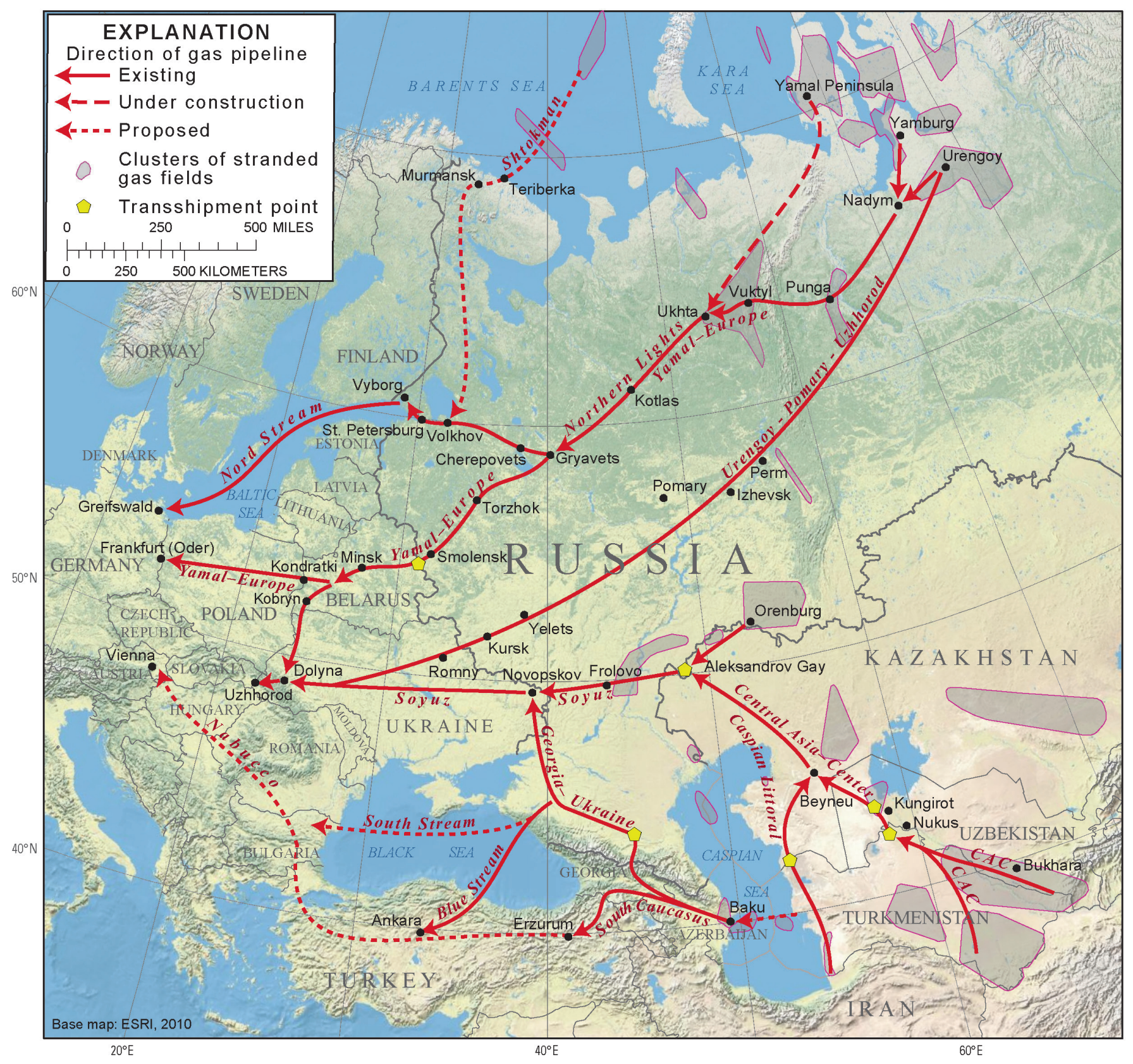

Figure 10. Map showing clusters of stranded gas fields and approximate locations of existing and proposed pipelines for delivery to transshipment points en route to Europe. Figure modified from Attanasi and Freeman (2012a). 


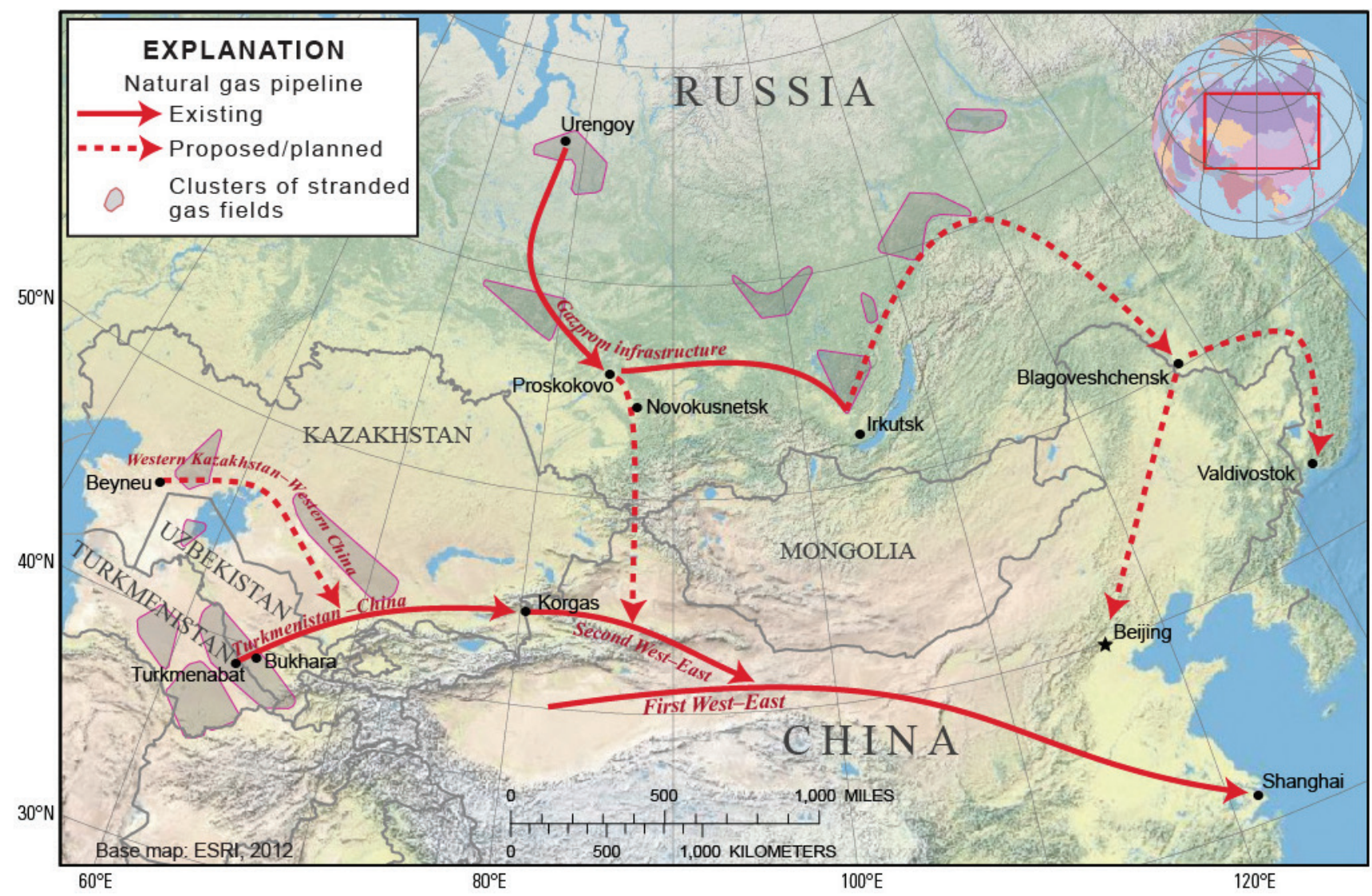

Figure 11. Map showing clusters of stranded gas fields and a schematic of approximate location of existing and proposed pipelines for delivery to China and Vladivostok, Russia. Figure modified from Attanasi and Freeman (2012b).

Stern and Rogers (2011) reviewed the natural gas price formation history of continental Europe and predicted that the major gas purchasers in continental Europe will abandon the oil-indexed pricing of natural gas and will index contract prices and changes to actual market prices. During the period from the latter part of 2008 through 2009, significant volumes of short-term shipments of LNG entered the UK and continental Europe. These shipments were priced according to current global gas market conditions. The desire to index long-term contracts to market-based prices came about because of the losses incurred by utilities that were obligated by take-or-pay contract provisions in their oil-indexed long-term contracts to buy gas that reflected soaring oil prices. The oil-indexed gas prices that were paid were well above market-based prices. These utilities then had to resell the gas to customers who had access to the market-priced LNG shipments. In order to sell the gas to these customers, the utilities had to price the gas below what they paid for the gas (Melling, 2010). In the aftermath, the litigation by the utilities to re-open contracts and partially restructure indexation provisions has met with some success (Andresen and Shiryaevskaya, 2012), as Gazprom is negotiating out-of-court settlements with its major European purchasers.

Natural gas exports to Asian markets have typically been supplied as LNG, and prices have commonly followed the pattern set by Japan's purchases of LNG. The Japanese Government's reaction to the oil disruptions of the 1970s was to implement a policy that subsidized the substitution of natural gas for oil in its industrial sector and for electricity generation. In the 1970s, LNG was the only practical way Japan could import natural gas. The Japanese Government assisted in financing LNG projects where Japanese electrical power and gas distribution utilities had equity positions and where utilities had long-term gas supply contracts. Long-term LNG contract prices were indexed to prices of a suite of crude oils. In most LNG supply projects in Southeast Asia and Australia, the national oil companies (NOCs) or utilities of the major gas-purchasing countries take equity positions in the liquefaction plants. Because these participating entities will sell their purchased gas into captive markets, they are likely less concerned about their purchase price than with other product dimensions, such as reliability of supply. 
Table 6. Pipeline capacity to transport gas to China and Singapore.

[See footnotes for sources. Some pipelines are shown in figure 11. BCF/D, billions of cubic feet per day; NA, not available]

\begin{tabular}{|c|c|c|c|c|}
\hline Pipeline & Origin & Destination & Status & $\begin{array}{c}\text { Capacity } \\
\text { (BCF/D) }\end{array}$ \\
\hline \multicolumn{5}{|c|}{ From central Asia to China } \\
\hline $\begin{array}{l}\text { Second West-East gas } \\
\text { pipeline }^{2}\end{array}$ & Korgas, China & Guangzhou, China & Built & 2.9 \\
\hline $\begin{array}{l}\text { Incremental upgrade to } \\
\text { Turkmenistan-China } \\
\text { pipeline }^{4}\end{array}$ & $\begin{array}{l}\text { Türkmenabat, } \\
\text { Turkmenistan }\end{array}$ & Korgas, China & Proposed & 3.4 \\
\hline $\begin{array}{l}\text { Western Kazakhstan-Western } \\
\text { China gas pipeline }{ }^{5}\end{array}$ & Beyneu, Kazakhstan & Korgas, China & Proposed & 1.0 \\
\hline \multicolumn{5}{|c|}{ From Russia to China } \\
\hline $\begin{array}{l}\text { Kovykta gas field-China/Korea } \\
\text { gas pipeline }{ }^{6}\end{array}$ & Kovykta gas field, Russia & China, South Korea & Dropped & 2.9 \\
\hline \multicolumn{5}{|c|}{ From Burma (Myanmar) to China } \\
\hline Myanmar-China gas pipeline $^{7}$ & Bay of Bengal, Burma & Kunming, China & Under construction & 1.2 \\
\hline \multicolumn{5}{|c|}{ From Southeast Asia to Singapore } \\
\hline NA & Sumatra, Indonesia & Singapore & Built & $\mathrm{NA}^{8}$ \\
\hline NA & Malaya, Malaysia & Singapore & Built & $\mathrm{NA}^{8}$ \\
\hline
\end{tabular}

${ }^{1}$ Gray and others (2003).

${ }^{2}$ China-Wire (2008).

${ }^{3}$ Yenikeyeff (2008).

${ }^{4}$ Socor (2012).

${ }^{5}$ Yenikeyeff (2008).

${ }^{6}$ Fridley (2008).

${ }^{7}$ Smith (2011).

${ }^{8}$ Pipeline deliveries to Singapore for 2011 according to BP (2012) were 0.7 BCF/D from Indonesia and 0.2 BCF/D from Malaysia. 
Table 7. Location and capacity of terminals receiving liquefied natural gas (LNG) in Europe.

[Data are from Gas Infrastructure Europe (2011). BCF/D, billions of cubic feet per day; dash (-), no data]

\begin{tabular}{|c|c|c|c|}
\hline Country & Name or location & $\begin{array}{l}\text { Existing capacity } \\
\text { (BCF/D) }\end{array}$ & $\begin{array}{l}\text { New or additional } \\
\text { capacity (BCF/D) }\end{array}$ \\
\hline Belgium & Zeebrugge & 0.9 & 0.3 \\
\hline \multirow[t]{4}{*}{ France } & Fos Cavaou & 0.8 & - \\
\hline & Fos Tonkin & 0.5 & - \\
\hline & Montoir de Bretagne & 1.0 & - \\
\hline & Dunkerque & - & 1.3 \\
\hline Greece & Revithoussa & 0.5 & 0.2 \\
\hline \multirow[t]{3}{*}{ Italy } & Panigaglia & 0.3 & - \\
\hline & Porto Levante & 0.7 & - \\
\hline & Toscana & - & 0.4 \\
\hline Netherlands & Rotterdam & 1.2 & 0.4 \\
\hline Poland & Swinoujscie & - & 0.5 \\
\hline Portugal & Sines & 0.6 & 0.1 \\
\hline \multirow[t]{9}{*}{ Spain } & Barcelona & 1.7 & - \\
\hline & Bilbao & 0.7 & 0.3 \\
\hline & Cartagena & 1.1 & 0.3 \\
\hline & El Ferrol & 0.3 & 0.4 \\
\hline & Huelva & 1.1 & 0.1 \\
\hline & Sagunto & 0.9 & 0.5 \\
\hline & Gijon & - & 0.7 \\
\hline & Gran Canaria & - & 0.1 \\
\hline & Tenerife & - & 0.1 \\
\hline \multirow[t]{2}{*}{ Turkey } & Aliaga & 0.6 & - \\
\hline & Marmara Ereglisi & 0.6 & - \\
\hline \multirow[t]{4}{*}{ United Kingdom } & Dragon & 0.6 & - \\
\hline & Isle of Grain & 1.9 & - \\
\hline & South Hook & 2.0 & - \\
\hline & Teesside & 0.4 & - \\
\hline Europe total & & 18.5 & 5.6 \\
\hline
\end{tabular}


Table 8. Location and capacity of liquefied natural gas (LNG) regasification terminals in Asia.

[Data are from True (2012). For each country, terminals are ordered from the earliest to the latest put into operation except that expansions are kept with the original terminal. $\mathrm{BCF} / \mathrm{D}$, billions of cubic feet per day; $\mathrm{TBD}$, to be determined]

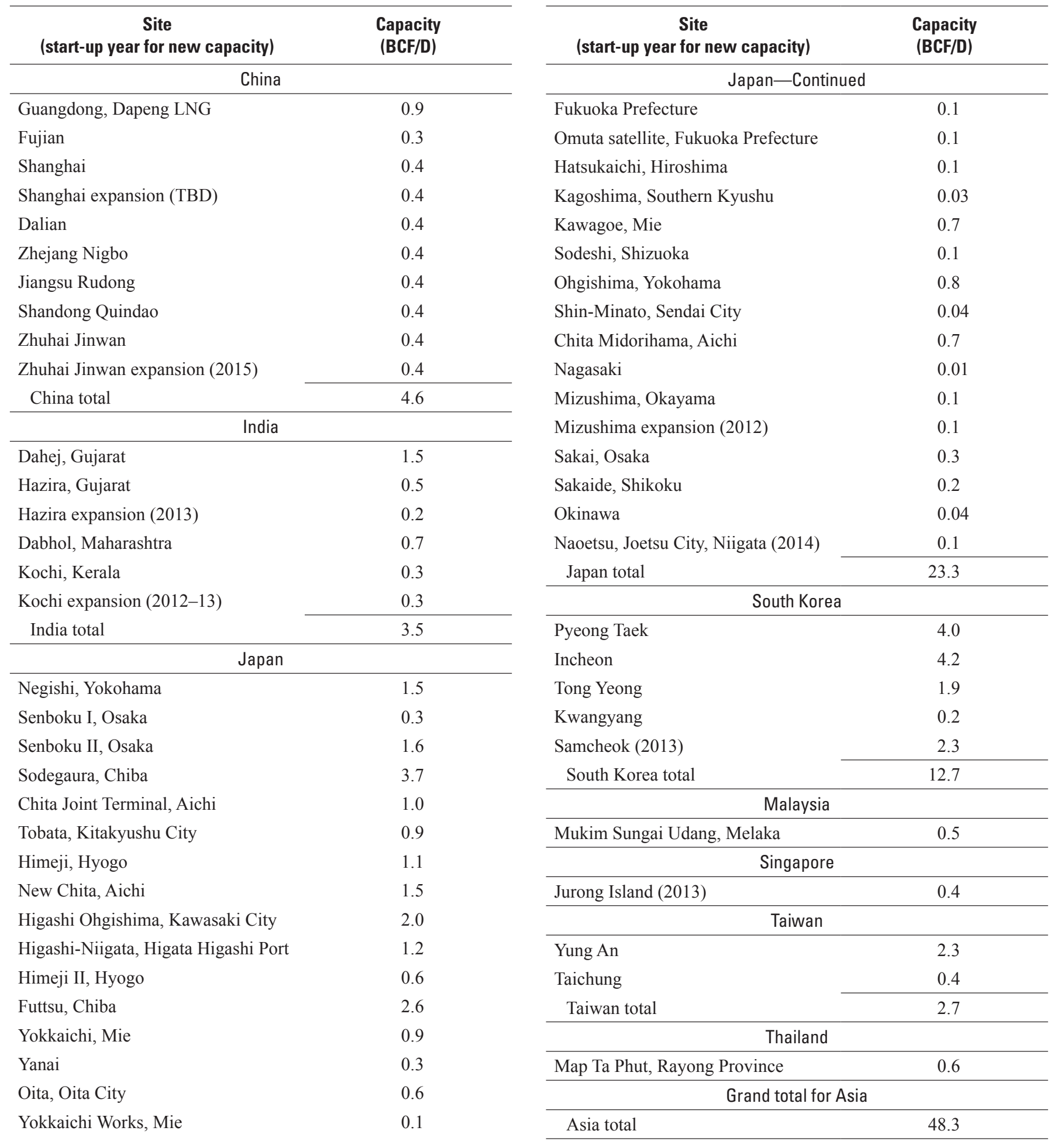




\section{Potential Growth in Europe's Demand for Imported Gas}

Neither this study nor the previous studies discussed above developed independent natural gas import demand projections for Europe. Instead, the projection from Volkov and others (2009) is used to provide a rough target for assessing the sufficiency of supply over a 20-year period starting in 2020. In 2008, Europe (or the EU27 plus group ${ }^{6}$ ) consumed 20.5 TCF of gas and produced 11.1 TCF of gas ${ }^{7}$ (U.S. Energy Information Administration (EIA), 2009a,b) and imported nearly 9.4 TCF of gas. The projection made by Volkov and others (2009) of Europe's gas imports was based on demand growth of 20 percent to 2020 over 2008 consumption and Europe's expected production decline of 11 percent from 2008 production. This trend widens the 2008 import gap between consumption and production by another 5.3 TCF per year (TCF/Y), or more than 14.5 BCF/D. Even if gas imports stabilize at the projected 2020 level, a 106-TCF tranche of imported gas is required over the next 20 years to accommodate the 5.3-TCF/Y import increase, and an additional $180 \mathrm{TCF}$ is required to meet the 2008 baseline import demand of 9.4 TCF/Y from 2020 through 2040. The original projections by Volkov and others (2009) take into account the desire of the European Union to reduce carbon dioxide emissions by reducing coal consumption. However, in May 2011, the German Government announced that it would no longer approve extensions to the permitted operating life of nuclear powerplants (Mufson, 2011). ${ }^{8}$ If natural-gas-fired plants were substituted for nuclear power generation, they would add about $2.5 \mathrm{BCF} / \mathrm{D}$, or about another 0.9 $\mathrm{TCF} / \mathrm{Y}$, to the baseline gas demand.

Several factors could moderate growth in the demand for imported gas over this period. The most notable is the possibility of commercially produced gas from gas-charged shale intervals. Producers in North America obtain commercial flow rates by drilling production wells with long horizontal laterals and hydraulically fracturing the reservoir rock in multiple locations along the lateral wellbore. Fracture treatments liberate the gas from the reservoir rock and provide pathways for the released gas to migrate to the well. In 2011, the EIA published a reconnaissance assessment of global shale gas resources prepared by Advanced Resources International (U.S. Energy Information Administration, 2011c). It estimated Europe's technically recoverable shale gas resources at 557 TCF with 187 TCF assigned to Poland, 180 TCF assigned to France, and 83 TCF assigned to Norway. There are mixed reports regarding the commercial producibility of the resource based on the early results of drilling. However, France has already prohibited the application of hydraulic fracturing, and other countries are considering similar prohibitions. The EIA (2011b) projected that even without any opposition to hydraulic fracturing, any European production of unconventional gas, such as shale gas, to 2020 would be very small.

\section{Potential Growth of Demand for Imported Gas in Japan, China, South Korea, and India}

The import demand projections for natural gas for Japan, China, South Korea, and India (Asia's current and potential leading importers of gas) are based on the EIA's reference case projection published in the 2011 International Energy Outlook (U.S. Energy Information Administration, 2011b). The gas import projections start at the historical base of $5.1 \mathrm{TCF} / \mathrm{Y}$ in 2008, grow to $9.5 \mathrm{TCF} / \mathrm{Y}$ in 2020, and reach $11.5 \mathrm{TCF} / \mathrm{Y}$ in 2030 (see table 9). The gas import demand projections may be derived as the difference in EIA's projections for each country's domestic gas demand and domestic gas supply. Over the projection period, Japanese and South Korean gas demands increase 0.3 percent per year and 1.4 percent per year, respectively. Domestic production of gas by Japan remains at about $0.2 \mathrm{TCF} / \mathrm{Y}$, and production by South Korea is much less than $0.05 \mathrm{TCF} / \mathrm{Y}$. Demand projections show growth in gas usage of 5.5 percent per year for China and 4.5 percent per year for India. During the forecast period, China's conventional gas production declines but is more than offset by production of unconventional gas to the point that by 2030, unconventional gas accounts for two-thirds of China's domestic production. The EIA reported China as having no unconventional gas production as of 2008. India's gas production increases to $3.6 \mathrm{TCF} / \mathrm{Y}$ in 2030 with $0.2 \mathrm{TCF} / \mathrm{Y}$ from unconventional gas.

The EIA reference case projection of future international gas trade is very conservative. Their gas and energy demand projections are predicated upon standard macroeconomic demand analysis. However, Wolfram and others (2012) argued that this approach inevitably underestimates the actual demand for developing countries such as India because it implicitly assumes that households are already served by electricity or the fuel in question. Projections of demand growth should also account for

\footnotetext{
${ }^{6}$ Europe's EU27 group includes Austria, Belgium, Bulgaria, Cyprus, Czech Republic, Denmark, Estonia, Finland, France, Germany, Greece, Hungary, Ireland, Italy, Latvia, Lithuania, Luxemburg, Malta, the Netherlands, Poland, Portugal, Romania, Slovakia, Slovenia, Spain, Sweden, and the United Kingdom. The "EU27 plus group" includes Norway and Switzerland.

${ }^{7}$ If the European former Soviet Republics outside of Russia are included, Europe's 2008 total consumption was 24.6 TCF and its 2008 production was 11.8 TCF.

${ }^{8}$ Switzerland will also close its nuclear powerplants by 2034, representing 0.5 BCF/D (Mufson, 2011). There is a potential of an additional 15-BCF/D increment to demand if all European countries with nuclear powerplants take similar action.
} 
Table 9. Two demand scenarios for net natural gas imports by country showing historical imports and projections into the future for Japan, South Korea, China, and India.

[EIA reference case projections are from U.S. Energy Information Administration (2011b). Volumes are in trillions of cubic feet per year (TCF/Y). Numbers may not add up due to rounding]

\begin{tabular}{|c|c|c|c|c|c|c|c|}
\hline \multirow{2}{*}{ Country } & \multicolumn{2}{|c|}{ Historical } & \multicolumn{5}{|c|}{ Projection } \\
\hline & 2008 & 2009 & 2015 & 2020 & 2025 & 2030 & 2035 \\
\hline \multicolumn{8}{|c|}{ Scenario 1: EIA reference case } \\
\hline Japan & 3.5 & 3.4 & 3.4 & 3.5 & 3.7 & 3.8 & 3.8 \\
\hline South Korea & 1.2 & 1.2 & 1.5 & 1.6 & 1.8 & 1.8 & 1.9 \\
\hline China & 0.0 & 0.1 & 2.4 & 3.3 & 4.1 & 4.5 & 4.6 \\
\hline India & 0.4 & 0.4 & 0.8 & 1.1 & 1.3 & 1.4 & 1.4 \\
\hline Total & 5.1 & 5.1 & 8.1 & 9.5 & 10.9 & 11.5 & 11.7 \\
\hline \multicolumn{8}{|c|}{ Scenario 2: Alternative case } \\
\hline Japan & 3.5 & 3.4 & 5.8 & 6.1 & 6.4 & 6.8 & 7.0 \\
\hline South Korea & 1.2 & 1.2 & 1.5 & 1.6 & 1.8 & 1.8 & 1.9 \\
\hline China & 0.0 & 0.1 & 6.0 & 8.2 & 12.5 & 16.3 & 18.9 \\
\hline India & 0.4 & 0.4 & 1.9 & 3.4 & 5.3 & 7.5 & 10.1 \\
\hline Total & 5.1 & 5.1 & 15.2 & 19.3 & 26.1 & 32.4 & 37.9 \\
\hline
\end{tabular}

the provision of electrical service to some of the more than 400 million people in India without it. ${ }^{9}$ Since the publication of the EIA projections, Japan announced it will close down it nuclear power generation industry (Inajima and Okada, 2011). China has announced a policy to increase gas usage for electricity generation to mitigate urban air quality degradation resulting from coalfired electricity generation (Aibing, 2012). India faces similar urban air quality issues.

A variation of the EIA reference project was devised that provided a plausible alternative gas import scenario. Although China consumes 46 percent of the global coal produced each year, EIA's reference projection assumed that China would continue to increase coal consumption by importing increasing volumes of coal. India consumes 7 percent of global coal supplies annually and imports about 22 percent of what it consumes annually, and its coal consumption under the reference projection continues to increase. As a plausible alternative scenario, it was assumed that gas is substituted for half of the projected incremental growth in coal use for electricity generation. This assumption added 4.9 TCF/Y to China's 2020 imports and 11.8 TCF/Y to its 2030 imports. This assumption, if applied to the EIA reference projection for India, would add $0.55 \mathrm{TCF} / \mathrm{Y}$ to imports in 2020 and $1.5 \mathrm{TCF} / \mathrm{Y}$ of gas in 2030, which accounts for only part of the difference between the EIA and alternative projections.

The EIA reference forecast for imported gas for India was also adjusted to bring electrical service by 2035 to about 70 percent of those now without electrical service. In particular, it was assumed that by 2035, 90 percent of India's projected population of 1,525 million people would be served by electricity. A linear extrapolation implies that 1.01 percent of the population is added annually between 2010 and 2035. If this incremental electricity demand were met by gas-fired generation powerplants, the additional gas imports to India would amount to $1.7 \mathrm{TCF} / \mathrm{Y}$ in 2020 and 4.6 TCF/Y in 2030.

Table 9 presents the EIA reference case and the alternative scenario. The alternative scenario is plausible for the following reasons: Japan has committed to closure of its nuclear power industry, predictions for China and India assumed that substitution of gas for coal would only slow the increases in coal usage for electricity generation, and India's expansion of the electrical service is a fundamental marker of its progress in economic development. The volumes of gas demand projected by the two scenarios for Asia are different. In order to meet demands starting in 2020 and going through 2040, under the EIA reference case, importers must secure $224 \mathrm{TCF}$ of gas, and for the alternative import demand scenario, they must secure $625 \mathrm{TCF}$ of gas without even allowing for additional growth in gas import demand beyond 2035. ${ }^{10}$

\footnotetext{
${ }^{9}$ By contrast, as of 2008, electrical service had been extended to 99.9 percent of China's population.

${ }^{10}$ This volume calculation was simply based on the average annual import demand for each of the 5 -year blocks from 2020 to 2035 , and the imports for 2035 were extended to 2040 .
} 


\section{Potential Additions to Supply from Development of Stranded Gas}

Results of the regional stranded gas studies are briefly reviewed before discussing the synthesis. First, a summary of the economic assumptions that were uniformly applied to each area is provided. The resources that were evaluated in each supply region are then discussed, and, finally, the cost functions are presented. Appendix 2 discusses the sources of cost data and the development assumptions used to compute those costs for representative onshore and offshore gas fields.

\section{Economic Cost Calculations and Assumptions}

The economic analysis assigns costs to the volumes of gas and liquids at stranded gas fields in the IHS International Petroleum Exploration and Production database (IHS Inc., 2009). Production facilities and transportation facilities are built with anticipation that revenues from production will repay all operation costs, taxes, and capital investments, as well as provide an after-tax return of at least 12 percent on investment. Costs include extraction and delivery of produced gas to a transshipment location near a proposed international pipeline or to a coastal area for conversion to LNG where it can be loaded onto seagoing tankers. The producer's unit cost, in U.S. dollars per thousand cubic feet of gas, is defined as the threshold price that must be paid at the transshipment or market location that is just sufficient to repay all capital investments, operating costs, taxes, and a 12-percent after-tax return on investment. If a representative gas field in a particular size and depth class (discussed in appendix 2 ) is commercially developable as indicated by a non-negative discounted net present value for a given price, then all fields in that size class and depth class located in the same cluster are assumed to be commercially developable.

In order for the resource cost functions for gas in stranded gas fields to reflect the physical differences in the field size distributions, depth (water and drilling), and remoteness, identical sets of fiscal parameters (income tax rate, royalty rate, required rate of return) were adopted for all areas. The common set of fiscal assumptions includes a 20-percent royalty rate, a 50-percent income tax (with recovery of capital through depreciation charges), and a 12-percent required after-tax return on investment. Costs are based on those that prevailed in the first quarter of 2008, and all computations are made in constant U.S. dollars. Onshore and offshore field development includes facilities to extract natural gas liquids (NGLs) from the production gas stream. ${ }^{11}$ The valuation attached to natural gas liquids was based on the assumption that crude oil prices were $\$ 70$ per barrel. Except where otherwise noted, costs of extraction and product transport to a transshipment location represent the cost of new facilities.

Transportation and liquefaction costs were based on a "cost of service" concept where tariffs and liquefaction tolls are set to recover operating costs, taxes, capital investment over the economic life of the pipeline or plant, and a 12-percent after-tax return on investment. For transporting gas, the "cost of service" concept used here assumes that new pipelines will be built along the rights-of-way of existing pipelines and that the computed tariffs reflect the full cost of service and the recovery of investment capital along with a return to capital. Within Russia, central Asia, and most gas-consuming countries of eastern Europe and east Asia, the gas pipeline network is controlled by the government or its operating company, which has been given monopoly status. The actual tariffs charged may be unrelated to the true cost of service and therefore may correspond poorly with the tariffs computed here. Similarly, some liquefaction plants in north Africa are owned by the government or state companies where costs are not transparent. Gas pipeline and liquefaction plants were assumed to be subject to a 50-percent income tax with recovery of capital through depreciation charges.

\section{Resources Evaluated for Europe's Markets}

The natural suppliers for Europe's gas market are the gas-exporting countries of north Africa and the Atlantic Basin, Russia, and selected gas-producing countries of central Asia. For the immediate future, Qatar is the only country in the Middle East with exports to Europe, and any expansion plans for production are tied to the North field (see appendix 1). Table 10 is a summary list of the volumes of resources evaluated for each supply region examined. The Atlantic Basin countries studied were Venezuela and Trinidad and Tobago in the Western Hemisphere and Nigeria in the Eastern Hemisphere. Both onshore gas and offshore gas in stranded gas fields in Nigeria (see fig. 3) were evaluated. In north Africa, the onshore stranded gas fields of Algeria and Libya and the offshore stranded fields of Libya and Egypt were evaluated (see fig. 2). A total of 178 TCF, or 81 percent, of the 219 TCF of gas in African offshore and onshore stranded gas fields shown in table 1 was evaluated. About 48 TCF was evaluated for offshore gas fields in Venezuela and Trinidad and Tobago, and 15 TCF was evaluated for onshore stranded gas in Venezuela. This represented about half of the 145 TCF of gas in stranded gas fields in South America.

\footnotetext{
${ }^{11}$ Although NGLs add significant economic benefits, the stranded gas field database did not provide consistently reliable estimates for NGLs. The U.S. Geological Survey's estimates of the ratio of natural gas liquids to dry gas for undiscovered gas were applied to calculate expected liquids recovery (U.S. Geological Survey World Energy Assessment Team, 2000). For areas without U.S. Geological Survey estimates, liquids-to-gas-ratio estimates of analog areas were used.
} 
Table 10. Stranded gas resources evaluated for European and Asian markets.

[Field data through the end of 2008 are from IHS Inc. (2009). Gas volumes are in trillions of cubic feet (TCF). Numbers may not add up due to rounding]

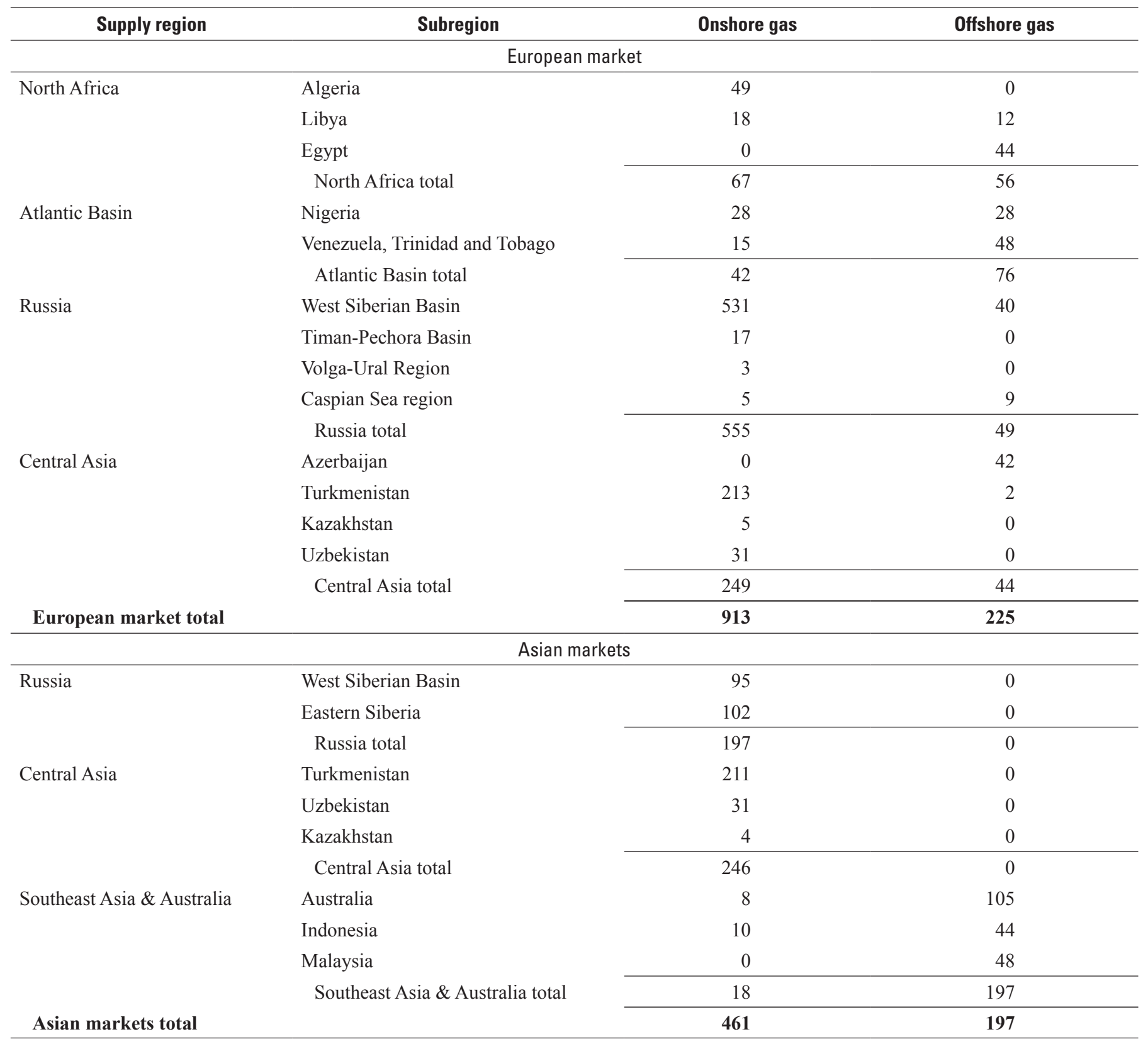

Europe is also currently supplied with pipeline gas from Russia. All of the central Asian gas-producing countries-Azerbaijan, Turkmenistan, Kazakhstan, and Uzbekistan — sell gas to Russia, which in turn, sells to domestic users and the former Soviet Republics of Belarus, Ukraine, and Moldova, besides Europe. Gas-exporting countries located on the eastern side of the Caspian Sea sell their gas exports to Russia, to neighboring countries, or to China. The seabed territorial claims of countries bordering the Caspian have not been adjudicated, and so underwater gas pipelines cannot be constructed. Some Azerbaijani gas flows to Europe through Turkey.

The Russian stranded gas fields that were evaluated for Europe's gas markets are located in the Timan-Pechora Basin, the West Siberian Basin, the Volga-Ural Region, and the bordering onshore and offshore areas of the Caspian Sea (see fig. 4). For these fields in Russia, a total of 555 TCF is in onshore stranded gas fields, and 49 TCF is in offshore stranded fields (table 10). The Russian stranded gas fields in the Barents Sea and a very small field in the Timan-Pechora Basin were not evaluated, nor were fields east of the West Siberian Basin. The volumes in stranded gas fields of Azerbaijan, Turkmenistan, Kazakhstan, and Uzbekistan (fig. 4) that were evaluated amounted to 249 TCF in onshore fields and 44 TCF in offshore fields, representing nearly 
all the gas in gas fields shown in table 1 for central Asia. As republics of the former Soviet Union, Azerbaijan, Turkmenistan, Kazakhstan, and Uzbekistan are already connected to the Gazprom pipeline system. However, without a trans-Caspian pipeline, the Gazprom pipeline network is the only way for Turkmenistan, Kazakhstan, and Uzbekistan to move gas to the west (see fig. 10). The cost calculations for the new pipelines to transport the additional supplies from stranded fields are assumed to use the established rights-of-way of the operating pipeline routes in figure 10, unless otherwise stated.

\section{Resources Evaluated for Asia's Markets}

Figure 5 shows the clusters of stranded gas fields in Russia and central Asia evaluated for supply of China. The far north cluster in the West Siberian Basin contained about 92 TCF of gas, and the other cluster due south in the same West Siberian Basin had 2.6 TCF of gas. Figure 11 shows the proposed route from these clusters south to the junction with China's West-East pipeline system. The five Russian stranded gas field clusters shown in figure 5 in the petroleum provinces of eastern Siberia contain 102 TCF in 35 stranded fields. One option for this gas is to supply Beijing, China. Gazprom has also announced plans to develop and transport some of the gas from the stranded gas fields of the Angara-Lena Terrace, the Baykit Arch, Nepa-Botuoba Arch, and the Lena-Vilyuy Basin of eastern Siberia (fig. 5) to planned LNG facilities at Vladivostok, Russia (Gazprom, 2012). The other undeveloped gas resources in the far eastern part of Russia, specifically the Sakhalin Islands, were not evaluated because much of the gas was considered associated gas or there were insufficient data on the gas accumulations in the database.

The transportation facilities shown for Russia in figure 11 include hypothetical pipelines that were posited to originate from the Gazprom network connecting the eastern clusters of the West Siberia basin at Urengoy to Proskokovo (due south), then connecting to China's Second West-East pipeline to either Shanghai or further south to Guangzhou. The route in figure 11 from the stranded gas clusters in eastern Siberia to Beijing, China, or Vladivostok, Russia, skirts Mongolia as a transit country. The hypothetical route originates near Irkutsk, then travels northeast to connect clusters within Russia. The pipeline then either enters China north of Beijing at Blagoveshchensk, Russia, or alternatively moves gas to a proposed LNG terminal at Vladivostok (Gazprom, 2012). The distance from Beijing to Shanghai, China, is about 670 miles (mi).

The market options for central Asian exporting countries east of the Caspian Sea are sales to Gazprom, sales to neighboring gas-consuming countries, and, more recently, sales to China. Total gas evaluated for the Asian market is 246 TCF, or 82 percent of the total stranded gas for central Asia shown in table $1 .{ }^{12}$ Gas from central Asia is delivered to China's West-East pipeline by the Turkmenistan-China pipeline or the Western Kazakhstan-Western China pipeline (fig. 11). Within China, pipeline routes were posited to deliver gas to Shanghai in eastern China (see fig. 11) and Guangzhou in south-central China. Many of these routes would follow pipelines built or proposed by China National Petroleum Corporation (CNPC). CNPC is building a network linking many industrial cities in eastern China with producing regions in the western part of China (China National Petroleum Corporation, 2012). The Turkmenistan-China pipeline shown in figure 11 is established, and expansions and (or) upgrades are scheduled to increase transport capacity from 2.9 BCF/D (Yenikeyeff, 2008) to 6.3 BCF/D (Socor, 2012).

The Southeast Asian countries of Indonesia and Malaysia have exported LNG for decades. All of Malaysia's stranded gas is offshore (fig. 6, table 10). The two offshore clusters adjacent to the Malay Peninsula together account for 29 TCF of gas and were excluded from consideration of LNG export development because this resource is likely to be dedicated to the domestic market. About 70 percent of the country's population lives in the Malay Peninsula (Ledesma, 2008). Stranded Malaysian gas fields holding $48 \mathrm{TCF}$ of gas were evaluated for export of LNG to the designated markets.

Indonesia has an estimated 81 million people (35 percent of its population) without electricity (Wolfram and others, 2012). Natural-gas-fueled generating plants have lower capital investment per kilowatt hour of installed capacity than either coal-fired plants or nuclear generating plants. However, because domestic prices are set much lower than international gas prices, gas producers are reluctant to sell gas to domestic users. The popular perception that gas exports cause domestic gas shortages has resulted in civil unrest (U.S. Energy Information Administration, 2011a). The government is under increasing pressure to ban exports from some projects and to require export projects to devote some of their production to the domestic market. Of the approximately $25 \mathrm{TCF}$ of gas in onshore stranded gas fields, $15 \mathrm{TCF}$ was located near dense population centers and was judged unlikely for export. Another 7 TCF of offshore gas resource was excluded from LNG evaluation because the field clusters were also located adjacent to population centers. Finally, the Natuna D-alpha field (in East Natuna Basin shown in fig. 6) was excluded because its development will likely require technology advances in carbon dioxide separation and sequestration. The field holds 42 TCF of methane entrained in 100 TCF of carbon dioxide (see Attanasi and Freeman, 2012b, for further details). Of the total 124 TCF of stranded gas initially identified for Indonesia, 54 TCF was evaluated for commercial LNG export (table 10).

\footnotetext{
${ }^{12}$ As discussed in text above (in the section, "Estimates of Stranded Gas outside North America"), the size of the largest field in central Asia, Turkmenistan's Yoloten-Osman field, was recently upgraded to between 460 and 750 TCF of gas (Gurt, 2011). This study, along with Attanasi and Freeman (2012a,b), used the IHS field size of less than 200 TCF.
} 
In Australia, two widely separated onshore clusters (total 1.5 TCF), located near the city of Perth and in the Gippsland Basin (not shown in fig. 7), and two offshore clusters of fields (3.4 TCF, in Gippsland and Otway Basins) were not evaluated because they could not sustain a commercial-scale LNG plant. During this study, several projects have been sanctioned, and their gas was removed from consideration in the cost analysis. The Pluto LNG project (Pluto field) and the Gorgon project (Gorgon and Janz/Io fields) in the Northwest Shelf (see fig. 7) removed 41.7 TCF from the stranded gas. In the Browse Basin (see fig. 7), the Browse project (Calliance, Torosa, and Brecknock1 fields) removed 20.8 TCF from the uncommitted reserves. The stranded gas fields evaluated for Australia held 105 TCF of recoverable gas offshore and 8 TCF onshore (table 10).

\section{Landed Costs of Stranded Gas for Europe's Markets}

\section{Gas from the Atlantic Basin and North Africa}

Costs of gas delivered to Europe from stranded gas fields included field development and extraction costs and the cost of transportation to an international pipeline or a coastal liquefaction plant. The liquefaction plant transforms the gas into LNG to be shipped by seagoing tanker to market. Countries that could supply Europe with stranded gas were categorized by broad geographic locations. The Atlantic Basin countries having stranded gas included Nigeria, Venezuela, and Trinidad and Tobago. North Africa included Algeria, Libya, and Egypt. Russia and central Asian gas exporters included Russia, Azerbaijan, Turkmenistan, Kazakhstan, and Uzbekistan.

Figure 12 and table 11 show the estimated resource cost of stranded gas delivered to existing LNG complexes or at international gas export pipelines from stranded gas fields located in the Atlantic Basin and north Africa. The functions show how estimated resource costs progressively increase as more costly tranches of stranded gas are committed to projects. All exports to Europe from Venezuela, Trinidad and Tobago, Nigeria, and Egypt were assumed to be in the form of LNG. Algeria was expected to export two-thirds by pipeline and the rest as LNG. More than 90 percent of Libya's gas exports was also expected to be transported by pipeline.

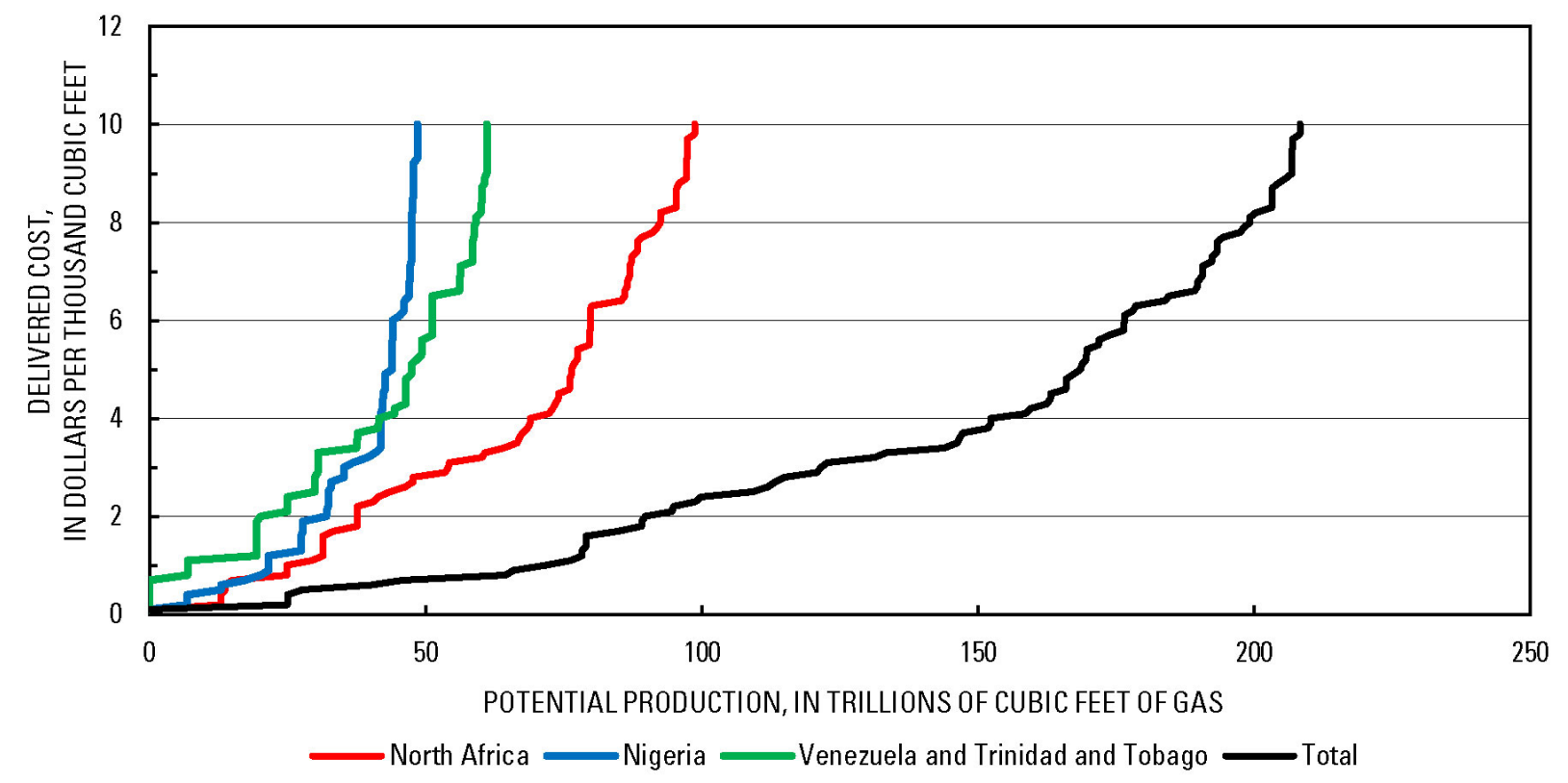

Figure 12. Graph showing estimated costs by region of developing, producing, and transporting stranded gas destined for Europe's markets to coastal transshipment locations. Curves show costs for north Africa and two regions in the Atlantic Basin-(1) Nigeria and (2) Venezuela and Trinidad and Tobago. Also shown is the sum of the three areas' curves, or total cost estimates as of early 2008 and in constant 2008 dollars. Table 11 shows costs for onshore and offshore stranded gas in each country in these three regions. 
Table 11. Estimated cost by country in north Africa and the Atlantic Basin for developing, producing, and transporting stranded gas destined for Europe's markets to coastal transshipment locations.

[\$MCF, dollars per thousand cubic feet in constant 2008 dollars; TCF, trillions of cubic feet]

\begin{tabular}{|c|c|c|c|c|c|c|c|c|c|}
\hline \multirow{2}{*}{$\begin{array}{l}\text { Delivered } \\
\text { cost at transship- } \\
\text { ment location } \\
\text { (\$/MCF) }\end{array}$} & \multicolumn{4}{|c|}{ Onshore } & \multicolumn{5}{|c|}{ Offshore } \\
\hline & $\begin{array}{l}\text { Algeria } \\
\text { (TCF) }\end{array}$ & $\begin{array}{l}\text { Libya } \\
\text { (TCF) }\end{array}$ & $\begin{array}{c}\text { Nigeria } \\
\text { (TCF) }\end{array}$ & $\begin{array}{l}\text { Venezuela } \\
\text { (TCF) }\end{array}$ & $\begin{array}{l}\text { Libya } \\
\text { (TCF) }\end{array}$ & $\begin{array}{l}\text { Egypt } \\
\text { (TCF) }\end{array}$ & $\begin{array}{l}\text { Nigeria } \\
\text { (TCF) }\end{array}$ & $\begin{array}{l}\text { Trinidad \& } \\
\text { Tobago } \\
\text { (TCF) }\end{array}$ & $\begin{array}{c}\text { Venezuela } \\
\text { (TCF) }\end{array}$ \\
\hline 1.00 & 14.9 & 10.0 & 17.1 & 0.0 & 0.0 & 0.0 & 4.4 & 0.0 & 6.9 \\
\hline 2.00 & 23.3 & 14.3 & 24.1 & 13.3 & 0.0 & 0.0 & 7.9 & 0.0 & 6.9 \\
\hline 3.00 & 30.5 & 14.8 & 25.0 & 13.8 & 0.0 & 8.8 & 10.2 & 9.8 & 6.9 \\
\hline 4.00 & 40.4 & 16.3 & 26.0 & 14.2 & 0.0 & 12.2 & 15.9 & 17.9 & 9.5 \\
\hline 5.00 & 44.3 & 16.7 & 26.8 & 14.2 & 3.2 & 12.2 & 17.1 & 19.9 & 13.4 \\
\hline 6.00 & 45.5 & 17.0 & 26.9 & 14.2 & 3.2 & 14.1 & 17.1 & 21.9 & 15.2 \\
\hline 7.00 & 46.7 & 17.2 & 27.1 & 14.4 & 8.6 & 14.5 & 20.1 & 26.6 & 15.2 \\
\hline 8.00 & 48.9 & 17.3 & 27.4 & 14.4 & 10.6 & 15.7 & 20.1 & 28.6 & 16.1 \\
\hline 9.00 & 49.1 & 17.5 & 27.7 & 14.5 & 10.6 & 20.0 & 20.1 & 30.4 & 16.1 \\
\hline 10.00 & 49.2 & 17.6 & 27.7 & 14.5 & 10.6 & 21.3 & 20.8 & 30.4 & 16.1 \\
\hline
\end{tabular}

Export gas from the stranded gas fields of Venezuela and Trinidad and Tobago was assumed to be transported to the LNG complex at Point Fortin, Trinidad..$^{13}$ The stranded gas fields in Trinidad and Tobago are offshore, and about 40 percent of Venezuela's stranded gas is offshore in the same area. Overall, Venezuela accounts for just over half of the $63 \mathrm{TCF}$ of total stranded gas (table 10). Figure 12 shows that at a transfer price of $\$ 3$ per thousand cubic feet (MCF) delivered to the LNG plant at Point Fortin, $30 \mathrm{TCF}$ of the identified stranded gas could be commercially developed, and at $\$ 5$ per MCF at the plant, 47 TCF could be developed. If one assumes that the volumes could be produced over a 25 -year period, the additional daily rate of production would represent 3.3 and 5.2 BCF/D of gas into the LNG plant. Alternatively, if one considers only the gas from Trinidad and Tobago as readily accessible to Europe, the commercial volume at $\$ 3$ per MCF would be 9.8 TCF $(1.1 \mathrm{BCF} / \mathrm{D})$, and at $\$ 5$, it would be 19.9 TCF (2.2 BCF/D) (table 11).

Figure 12 also shows the estimated costs of developing and delivering gas from onshore and offshore stranded gas fields in Nigeria to the LNG complex at Bonny, Nigeria. Produced gas from stranded fields was assumed to be collected at hubs at Forcados and Bonny (fig. 3). Gas collected at Forcados was assumed to be transported by pipeline about 270 mi overland to the Bonny liquefaction complex. At inlet gas prices of $\$ 3$, about $25 \mathrm{TCF}(2.7 \mathrm{BCF} / \mathrm{D})$ of gas from onshore stranded fields and $10 \mathrm{TCF}(1.1 \mathrm{BCF} / \mathrm{D})$ of gas from offshore fields were estimated to be commercially developable (table 11). Similarly at $\$ 5$ per $\mathrm{MCF}$, the estimated commercial volumes were 26.8 TCF (2.9 BCF/D) of onshore gas and 17.1 TCF (1.9 BCF/D) of offshore gas.

The estimated resource cost function associated with north African stranded gas (fig. 12) included costs of field development, extraction, and transport to the coastal locations of existing LNG plants or trans-Mediterranean pipelines (see fig. 2). The lowest cost stranded gas fields are located in onshore Algeria and Libya. At $\$ 3$ per MCF and $\$ 5$ per MCF, there were estimated to be about $54 \mathrm{TCF}$ and $76 \mathrm{TCF}$ that could be produced commercially from Algeria, Libya, and Egypt and transported to a coastal transshipment location (table 11). If this volume of gas were produced over a 25 -year period, additional production would amount to $5.8 \mathrm{BCF} / \mathrm{D}$ and $8.3 \mathrm{BCF} / \mathrm{D}$.

The cost of delivering pipeline gas from Mellitah, Libya, to Gela, Italy, was computed by applying the technical data and cost estimates from the GreenStream pipeline (fig. 9) with the common fiscal assumptions. The estimated tariff is $\$ 2.91$ per MCF. The cost for transporting gas along the route of the planned GALSI pipeline from El Kala, Algeria, to Italy (fig. 9) is estimated to be $\$ 2.90$ per MCF. Alternatively, the cost of the service tariff to transport the planned limited volume of gas along the MEDGAZ route (fig. 9) from Beni Saf, Algeria, to Almeria, Spain, was estimated at $\$ 1.60$ per MCF. If one assumes that the cost of pipeline delivery from north Africa to Europe is not more than $\$ 3.00$ per MCF and each cubic foot of gas has a calorific value of 1,070 British thermal units (Btu), the cost of delivery is about $\$ 2.84$ per million British thermal units (MMBtu). If only volumes of gas from Algeria and Libya are available for pipeline shipment, then at $\$ 3.00$ per MCF, 45 TCF (table 11) could be developed and then delivered by pipeline to southern Europe at a cost of $\$ 5.84$ per MMBtu.

\footnotetext{
${ }^{13}$ Some of the LNG trains in the Point Fortin LNG complex are merchant trains and will liquefy the gas for a toll.
} 
Table 12. Estimated cost of liquefying and transporting natural gas as LNG from the source country to the destination regasification facility if the process gas cost were $\$ 3.00$ per thousand cubic feet.

[\$/MMBtu, dollars per million British thermal units in constant 2008 dollars]

\begin{tabular}{llccc}
\hline \multirow{2}{*}{ Source country } & \multicolumn{1}{c}{ Destination } & $\begin{array}{c}\text { Sailing distance } \\
\text { (nautical miles) }\end{array}$ & \begin{tabular}{c} 
Landed cost (\$/MMBtu) \\
\cline { 3 - 4 } rate of return
\end{tabular} & $\begin{array}{c}\mathbf{9 \%} \\
\text { rate of return }\end{array}$ \\
\hline \multirow{2}{*}{ Trinidad and Tobago } & South Hook, UK & 3,603 & 8.82 & 7.76 \\
& Gibraltar, Spain & 3,403 & 8.74 & 7.69 \\
\multirow{3}{*}{ Egypt } & South Hook, UK & 3,797 & 8.89 & 7.82 \\
& Belgium & 4,187 & 9.04 & 7.94 \\
Algeria & South Hook, UK & 2,791 & 8.51 & 7.50 \\
& La Spezia, Italy & 1,434 & 7.99 & 7.08 \\
Libya & South Hook, UK & 1,244 & 7.92 & 7.02 \\
& La Spezia, Italy & 682 & 7.71 & 6.85 \\
& South Hook, UK & 2,377 & 8.35 & 7.37 \\
\hline
\end{tabular}

Across Europe, various destinations accept LNG shipments. The liquefaction complex includes processes for gas conditioning, cooling, and storage and has facilities to load the LNG on specially designed seagoing tankers. A discussion of the cost analysis is presented in appendix 3. Nigeria, Trinidad and Tobago, and Egypt have modern LNG complexes that are already considered to be of the size needed to take advantage of scale economies. It was therefore assumed that increments to LNG capacity would be accomplished by adding a train that could produce 5 million metric tons per year (MTY). These trains are sufficiently large that additional storage and improved loading facilities are likely to be required. Table 11 shows that each of the three countries had at least the minimum volume of 7.1 TCF in stranded gas to supply an additional 5-MTY train for 25 years.

All the gas marketed to Europe from Egypt and the Atlantic Basin countries described above is in the form of LNG. The LNG from Trinidad and Tobago and Nigeria was assumed to be marketed at South Hook, United Kingdom (UK). LNG from Egypt, Algeria, and Libya was assumed to be marketed in South Hook, UK, or La Spezia, Italy. Table 12 shows the cost of the landed gas based on an inlet gas price of $\$ 3.00$ per MCF to the plant. The table shows the originating country in the first column, the destination in the second, the sailing distance (nautical miles, nmi) in the next column, and then the landed cost of gas depending on whether the required return was 12 percent or 9 percent for liquefaction and shipping components of the LNG chain. Calculations were based on the fiscal assumptions and capital costs described in appendix 3. For the LNG base case of a 12-percent required return, landed costs range from $\$ 7.71$ to $\$ 9.04$ per MMBtu. For north African suppliers, it was much less costly to deliver gas to southern Europe than to South Hook, UK. However, the costs for Algerian and Libyan LNG are greater than costs of pipeline gas because the costs of liquefaction and tanker transport exceed the pipeline transport cost. If one assumed an LNG plant inlet gas price of $\$ 3.00$ per MCF, the actual unit costs of liquefying gas and transporting the LNG across the Mediterranean would be about $\$ 4.28$ per MMTBU. If the regasification cost averaged about $\$ 0.50$ per MMBtu, then LNG landed costs would exceed pipeline transport costs by about $\$ 1.94$ per MMBtu.

For a representative LNG plant at the same scale, same fiscal assumptions, and having gas cost of $\$ 3.00$ per MCF at the LNG plant, with the LNG shipped 2,000 nmi to market, the supply chain costs are the following: gas inlet cost, 36 percent; liquefaction cost, 52 percent; and transportation from plant to market, 12 percent. Reducing the capacity of the liquefaction trains progressively increases the share of liquefaction costs because scale economies are lost. Additional computations showed sensitivity of delivered cost to the assumed required after-tax rate of return, inlet gas cost, and shipping distance. The last column in table 12 shows that if the required after-tax return were reduced from 12 to 9 percent, then landed prices would decline by about 12 percent. A sensitivity study shows that for an increase in the LNG plant's process gas costs of \$1 per MCF, the landed cost would increase by about $\$ 1.15$ per MMBtu assuming the 5-MTY train and a 2,000-nmi trip to market. 
Table 13. Estimated cost of developing, producing, and transporting gas from stranded gas fields in Russia by petroleum province or producing area to the border of the European Union at Uzhhorod, Ukraine.

[\$MCF, dollars per thousand cubic feet in constant 2008 dollars; TCF, trillions of cubic feet. Numbers may not add up due to rounding]

\begin{tabular}{ccccccccc}
\hline \multirow{2}{*}{$\begin{array}{c}\text { Delivered } \\
\text { Cost } \\
\text { (\$/MCF) }\end{array}$} & \multicolumn{9}{c}{$\begin{array}{c}\text { Onshore } \\
\text { West Siberia } \\
\text { (TCF) }\end{array}$} & $\begin{array}{c}\text { Timan- } \\
\text { Pechora } \\
\text { (TCF) }\end{array}$ & $\begin{array}{c}\text { Volga-Ural } \\
\text { (TCF) }\end{array}$ & $\begin{array}{c}\text { Caspian } \\
\text { (TCF) }\end{array}$ & & \multicolumn{3}{c}{$\begin{array}{c}\text { Offshore } \\
\text { West Siberia } \\
\text { (TCF) }\end{array}$} & $\begin{array}{c}\text { Caspian } \\
\text { (TCF) }\end{array}$ & $\begin{array}{c}\text { Total } \\
\text { (TCF) }\end{array}$ \\
\hline 4.00 & 0.0 & 0.0 & 0.0 & 0.0 & & 0.0 & 0.0 & 0.0 \\
5.00 & 0.0 & 0.0 & 0.8 & 0.5 & & 0.0 & 0.0 & 1.3 \\
6.00 & 0.0 & 8.0 & 1.9 & 0.5 & & 0.0 & 0.0 & 10.4 \\
7.00 & 226.6 & 13.6 & 2.0 & 0.7 & & 0.0 & 5.9 & 248.9 \\
8.00 & 439.3 & 15.0 & 2.0 & 0.7 & & 0.0 & 5.9 & 463.0 \\
9.00 & 492.6 & 15.0 & 2.5 & 0.7 & & 0.0 & 5.9 & 516.7 \\
10.00 & 509.5 & 15.0 & 2.5 & 0.7 & & 0.0 & 7.8 & 535.6 \\
\hline
\end{tabular}

\section{Gas from Russia and Central Asia}

Figure 10 shows the major gas pipeline delivery routes to markets in Europe from Russia and central Asia. Central Asian gas producers have limited options to transport gas to western markets. Central Asian producers are required to sell gas to Gazprom where it enters the Russian pipeline system. Gazprom will resell the gas to domestic or European customers. Azerbaijan is the only central Asian producer that currently has the ability to move gas through Turkey and to sell directly to Europe. The estimates of the cost of transporting the additional supplies from stranded gas are based on "the cost of service" procedures. Tariffs are for new pipelines that would be located along the Gazprom right-of-way. Table 10 and figure 4 show that the largest volumes of Russia's stranded gas inventory that was evaluated for Europe's markets are located in the arctic areas of the West Siberian Basin. Table 10 shows that only 42 TCF of the 293 TCF of central Asian gas evaluated for Europe is in Azerbaijan.

Figure 13 is reproduced from Attanasi and Freeman (2012a), and table 13 shows corresponding gas volumes available at landed costs up to $\$ 10$ per MCF. Figures $13 A$ and $13 B$ show that for Russia, the primary major gas tranche of 227 TCF from West Siberia's Yamal Peninsula has a threshold delivered cost of $\$ 7.00$ per MCF. There are small volumes of gas up to that entry cost, but their sum is less than $22 \mathrm{TCF} .{ }^{14}$ This analysis assumed an overland route where Yamal gas would flow in pipelines adjacent to the existing Yamal-Europe, Northern Lights pipeline systems (fig. 10). The cost would be about $\$ 0.69$ per MCF greater for a route across the Baltic Sea along the Nord Stream pipeline to Germany assuming the "cost of service" procedure for computing tariffs. Table 13 shows the estimated costs that must be incurred in developing, producing, and transporting various quantities of gas from stranded gas fields in Russia by producing area.

Figures $13 C$ and $13 D$ show the estimated cost of delivered stranded gas to Europe from central Asia. The figures show that the principal tranches of gas from Azerbaijan and Turkmenistan have threshold delivered costs of $\$ 4.50$ per MCF and $\$ 5.00$ per MCF, respectively. Although the western areas of Kazakhstan and Uzbekistan can deliver gas at a somewhat lower cost, the gas volumes are less than 10 TCF. Table 14 shows the estimated cost that must be incurred in developing, producing, and transporting various quantities of gas from stranded gas fields in central Asia by country. The extra costs associated with gas development, production, and pipeline transportation under severe arctic conditions are the reasons why the estimated delivered cost for the Yamal gas from Russia is greater than costs for the two principal tranches from central Asia. ${ }^{15}$

Transportation accounts for a large component of the delivered costs. The estimated delivered cost is $\$ 7.00$ per MCF at Uzhhorod, Ukraine, from Yamal stranded gas fields. About 82 percent of the delivered cost is attributable to transportation. About 75 percent of the $\$ 5.00$ per MCF threshold delivered costs at Uzhhorod, Ukraine, from the large tranche of Turkmeni gas in the Amu Darya Basin is ascribed to transportation.

\footnotetext{
${ }^{14}$ In particular, there are 14 TCF from the Timan-Pechora Basin petroleum province, 6 TCF from Caspian fields, and 2 TCF from the Volga-Ural Region (fig. 4).

${ }^{15}$ Pipeline distances from the Yamal field to Uzhhorod, Ukraine, are between 2,300 and 2,600 miles (mi). Uzhhorod is 2,100 mi from the principal field in Azerbaijan and 2,300 mi from the Turkmenistan field.
} 
$\boldsymbol{A}$

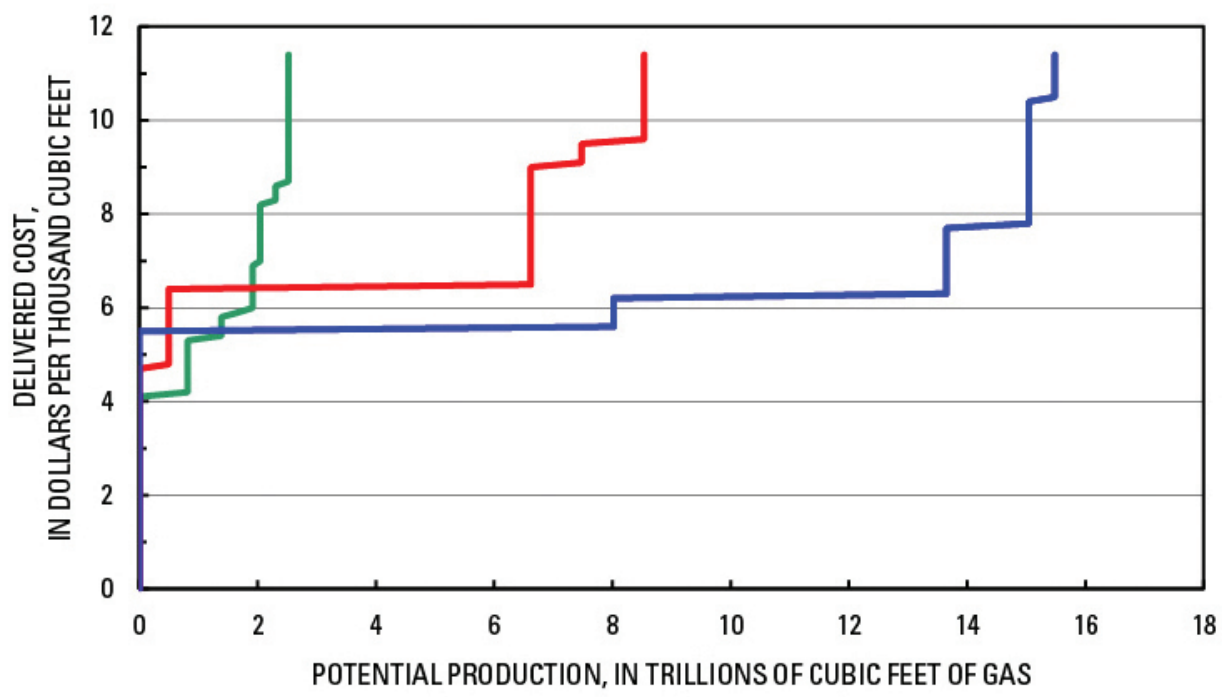

Volga-Ural Caspian Timan-Pechora

B

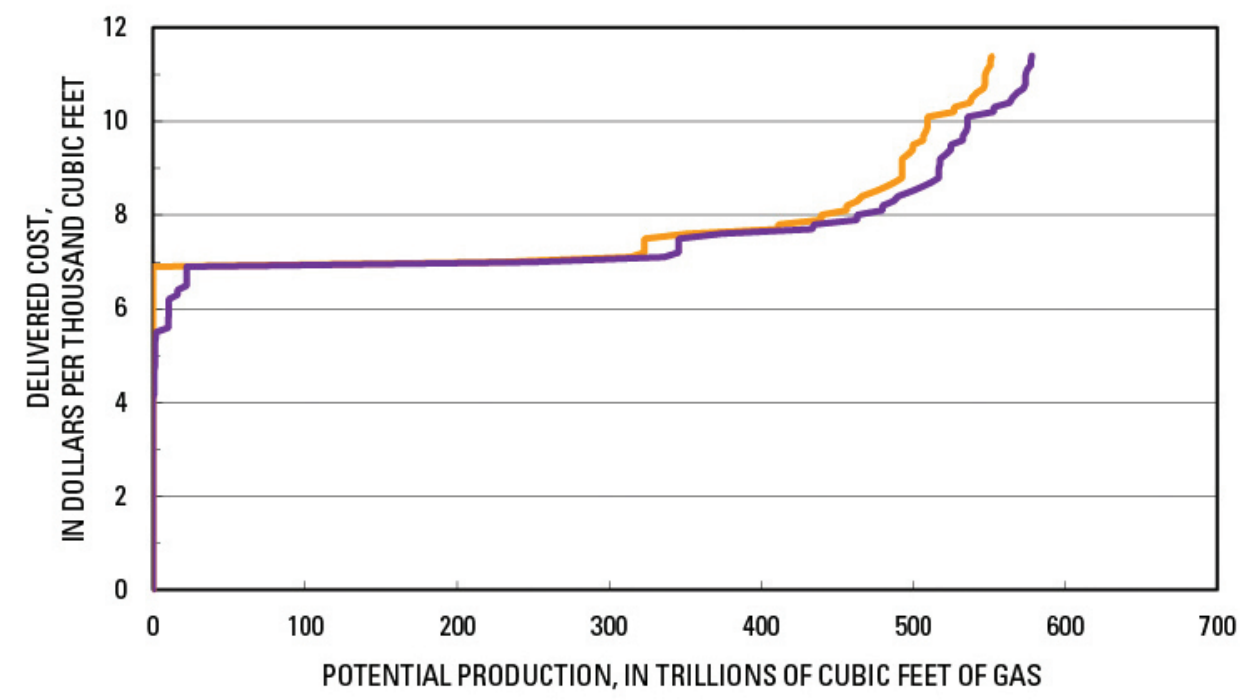

Western Siberia $\quad$ Total Russia

Figure 13. Graphs showing estimated costs by region of developing, producing, and transporting stranded gas destined for Europe's markets to the market point at the European Union border at Uzhhorod, Ukraine. A, Resource cost curves for Volga-Ural, Caspian, and Timan-Pechora provinces. $B$, Resource cost curves for western Siberia and the total stranded Russian gas resource from the above provinces. $C$, Resource cost curves for Kazakhstan, Uzbekistan, and Azerbaijan. $D$, Resource cost curves for Turkmenistan and the total stranded gas resource in central Asia from the four countries. Cost estimates as of early 2008 and in constant 2008 dollars. Horizontal scales vary. Figure modified from Attanasi and Freeman (2012a). 


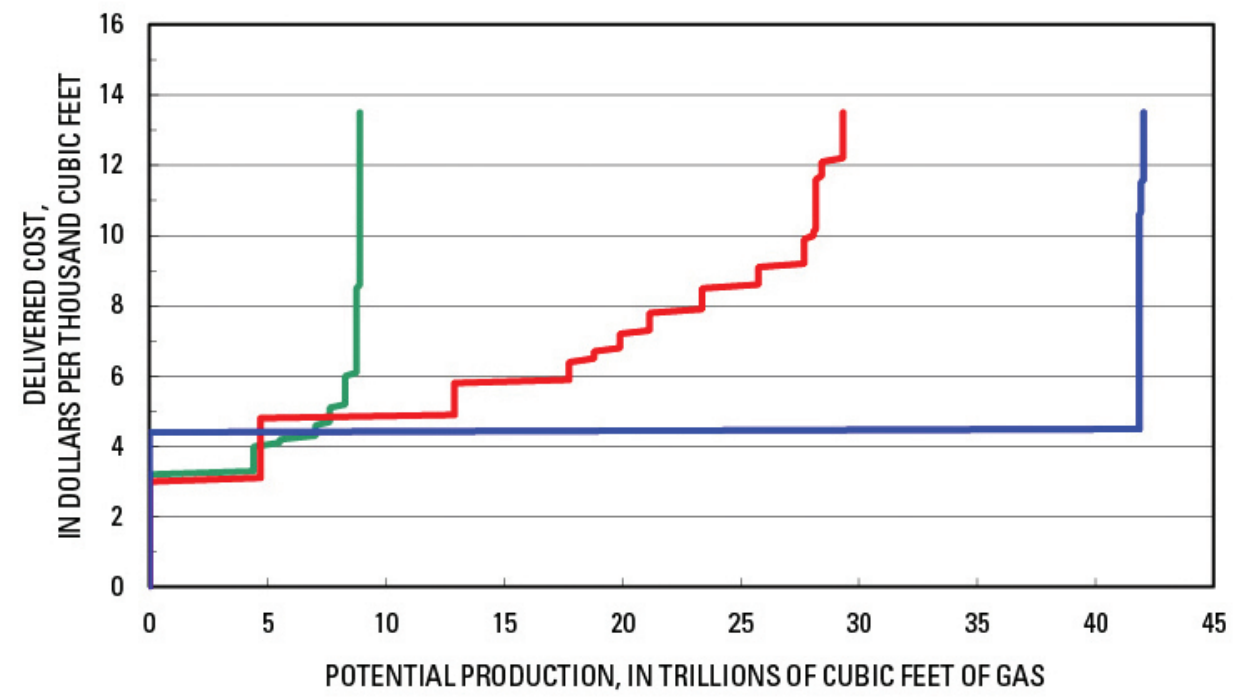

Kazakhstan Uzbekistan $\longrightarrow$ Azerbaijan

D

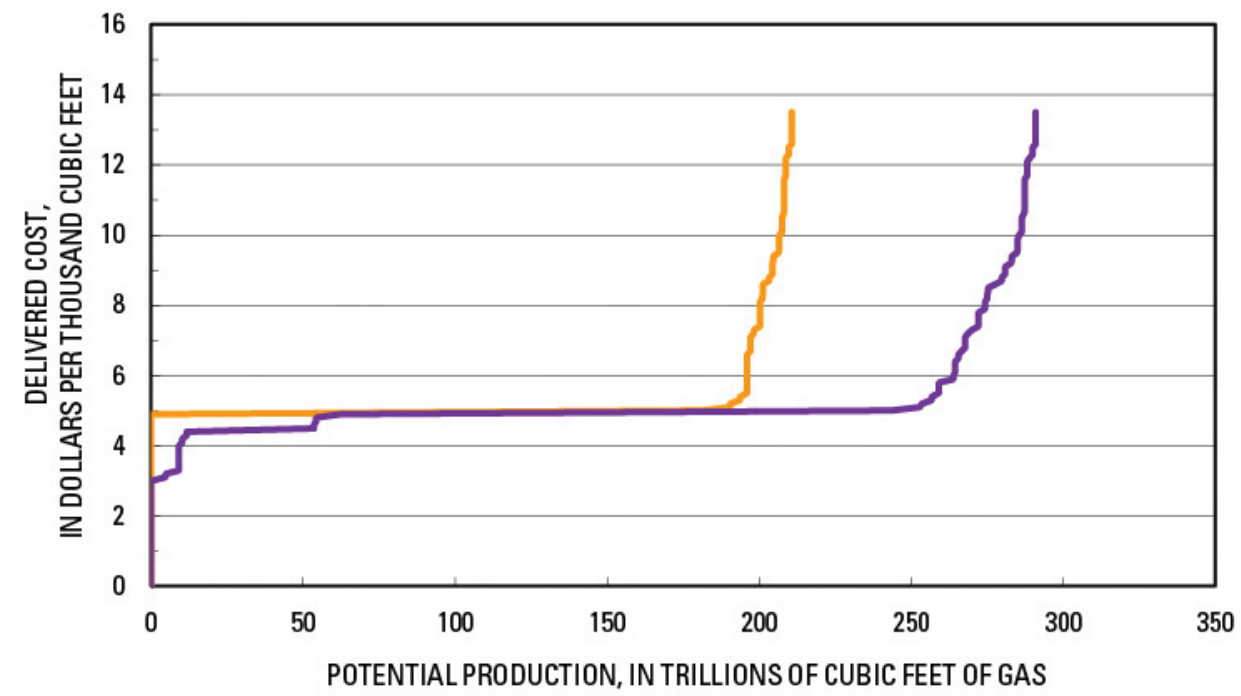

Figure 13. Continued. 
Table 14. Estimated cost of developing, producing, and transporting gas from stranded gas fields in central Asia by country to the border of the European Union at Uzhhorod, Ukraine.

[\$/MCF, dollars per thousand cubic feet in constant 2008 dollars; TCF, trillions of cubic feet. Numbers may not add up due to rounding]

\begin{tabular}{cccccc}
\hline $\begin{array}{c}\text { Delivered cost } \\
\text { (\$/MCF) }\end{array}$ & $\begin{array}{c}\text { Azerbaijan } \\
\text { (TCF) }\end{array}$ & $\begin{array}{c}\text { Turkmenistan } \\
\text { (TCF) }\end{array}$ & $\begin{array}{c}\text { Uzbekistan } \\
\text { (TCF) }\end{array}$ & $\begin{array}{c}\text { Kazakhstan } \\
\text { (TCF) }\end{array}$ & $\begin{array}{c}\text { Total } \\
\text { (TCF) }\end{array}$ \\
\hline 3.10 & 0.0 & 0.0 & 4.7 & 0.0 & 4.7 \\
4.00 & 0.0 & 0.0 & 4.7 & 4.4 & 9.1 \\
5.00 & 41.9 & 181.3 & 12.9 & 7.6 & 243.7 \\
6.00 & 41.9 & 196.0 & 17.8 & 8.3 & 263.9 \\
7.00 & 41.9 & 197.2 & 19.9 & 8.8 & 267.7 \\
8.00 & 41.9 & 200.3 & 23.4 & 8.8 & 274.2 \\
9.00 & 41.9 & 204.4 & 25.7 & 8.9 & 280.9 \\
10.00 & 41.9 & 206.5 & 28.1 & 8.9 & 285.3 \\
\hline
\end{tabular}

\section{Implications for Meeting Europe's Future Demand for Imported Gas}

There are sufficient gas resources in the stranded gas fields in Russia, central Asia, north Africa, and the Atlantic Basin to sustain the higher gas import demand estimated for Europe during the next several decades. If markets are competitive, these supplies could be available at costs that are well within the historical experience of Europe's gas users. During the period from 2008 to 2010, average pipeline gas prices to Hungary ranged from $\$ 9.02$ to $\$ 11.97$ per MMBtu, and LNG prices to Spain averaged from \$7.14 to \$9.22 per MMBtu (International Energy Agency (IEA), 2011). In addition, LNG costs shown in table 12 (which assumes an LNG plant input gas price of \$3 per MCF) are competitive with Russian threshold pipeline prices. The resource cost functions of figure 12 are important in terms of comparing the cost of north African gas supplies by pipeline with costs of supplies from Russia and central Asia. North African countries of Algeria and Libya have 37 TCF of stranded gas that can be commercially produced and delivered to southern Europe at a cost of \$5.00 per MCF assuming a \$3 per MCF trans-Mediterranean pipeline tariff. The discussion above noted that for each $\$ 1$ change in the inlet gas cost per MCF to the LNG plant, the landed costs of the LNG in Europe would change by \$1.15 per MMBtu. If one drops the LNG plant inlet gas cost to \$2.00 per MCF, calculated delivered costs would all be less than $\$ 8$ per MCF and would be competitive with Russia's costs. The European Union is quite concerned with security of supply as a policy and the consequences of a single supplier having a significant market share. Relative comparability of costs suggests that it is not necessary to accept wide price differences among suppliers to obtain diversity of supply.

From a security viewpoint, other risks are not trivial. In all cases, the supply chain from the gas field to the European market is long. In the case of Russia and central Asia, supply can be disrupted by disputes with transit countries. The additional step of liquefaction and the special transport of LNG require large investments from the suppliers unless prospective purchasers take significant equity positions in the projects. However, such equity investments carry their own risks, which depend on the stability and reliability of their partners. With the exception of Trinidad and Tobago, the role of the host government as represented by its national oil and gas company is important in terms of any risk calculation. Risk mitigation measures may reduce the required after-tax return on investment. For example, table 12 shows the effect of reducing the required return from 12 to 9 percent on the threshold price necessary for the LNG project to be commercial.

\section{Landed Costs of Stranded Gas for Asia's Markets}

\section{Gas from Russia and Central Asia}

The cost of delivered gas to Shanghai, China, was calculated for two clusters in the West Siberian Basin (fig. 5). The northern cluster, holding 92 TCF in stranded gas fields, was also evaluated for delivery to Europe in a section above. However, its removal from consideration for delivery to Europe does not materially affect the conclusions of the previous section. Its initial entry cost to Europe is $\$ 7.70$ per MCF with a tranche of 39 TCF. For the analysis of these two clusters in markets of Asia, it is assumed that the produced gas from these fields would be transported south to the West-East China pipeline and then southeast to Shanghai. Stranded gas in the gas field clusters from eastern Siberia (fig. 5) was also evaluated for the Shanghai market. 


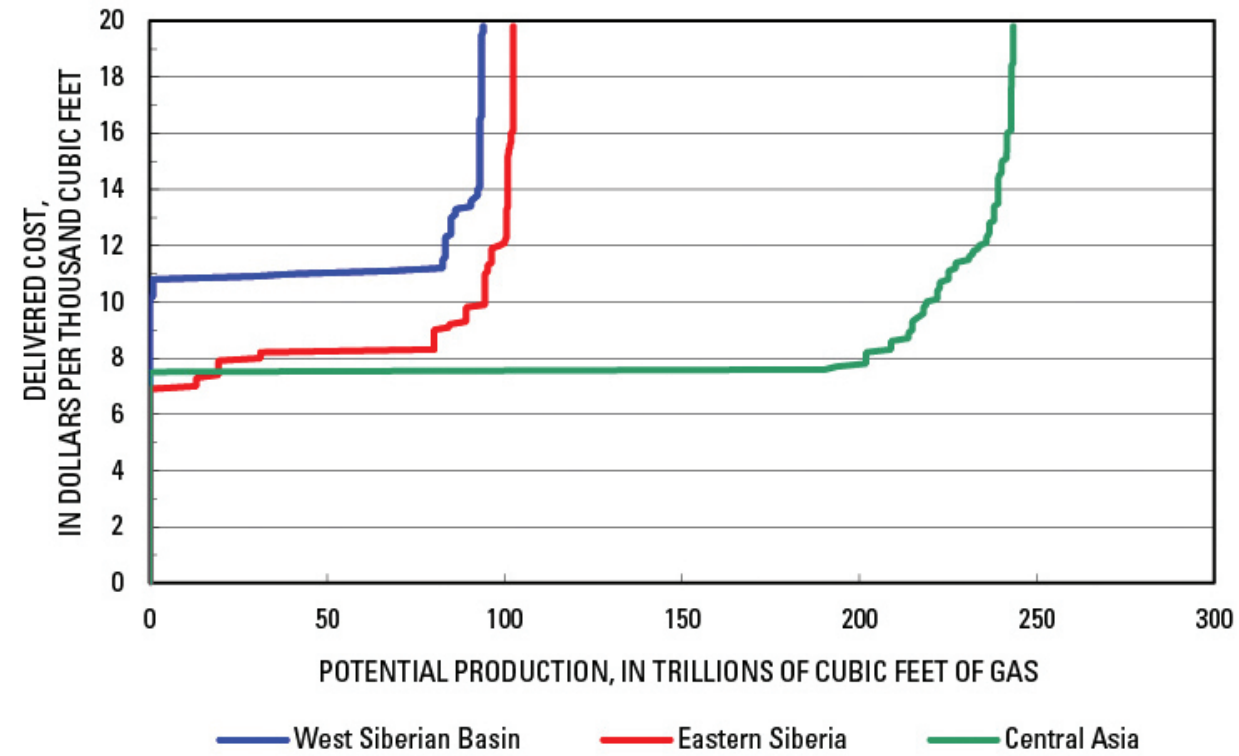

Figure 14. Graph showing estimated costs of developing, producing, and transporting stranded gas to Shanghai, China, from the West Siberian Basin, eastern Siberia, and central Asia (Turkmenistan, Uzbekistan, and Kazakhstan). Cost estimates as of early 2008 and in constant 2008 dollars. Figure modified from Attanasi and Freeman (2012b).

The gas from these clusters would be collected along the pipeline that originates near Irkutsk. The hypothetical pipeline would collect gas within Russia, moving gas northeast and then south to enter China near Blagoveshchensk, Russia (fig. 11). The gas would then flow directly south to Beijing and southeast to Shanghai. Estimates were also made of the cost of delivered gas to Shanghai from central Asian producers located east of the Caspian Sea. The Turkmenistan-China pipeline currently delivers gas from the Amu Darya Basin in Turkmenistan to China's West-East pipeline at the Kazakhstan-China border, traversing Uzbekistan and Kazakhstan. Additional pipelines are expected to be located along the same right-of-way of the Turkmenistan-China pipeline to increase exports from Turkmenistan and allow gas exports from Kazakhstan and Uzbekistan.

The results of these delivered cost computations reproduced from Attanasi and Freeman (2012b) are expressed as resource cost functions in figure 14. If one considers only clusters with at least 10 TCF of gas, the delivered costs for the West Siberian Basin stranded gas clusters are 20 to almost 35 percent greater than the cost of gas from eastern Siberia. Though the northern West Siberian Basin stranded field cluster has larger fields, their location near the Arctic Circle results in much higher extraction and pipeline transportation costs than costs for the Amu Darya Basin of central Asia, for example (fig. 5). Furthermore, the distance to Shanghai is almost 4,200 mi compared to 3,500 mi from the Amu Darya Basin and about 2,500 mi from Russia's stranded gas in eastern Siberia (fig. 11).

\section{Liquefied Natural Gas from Southeast Asia, Australia, and Russia}

Indonesia, Malaysia, and Australia export gas as LNG because their primary markets are overseas. Although Indonesia has exported LNG since the 1970s, new LNG projects have evoked civil unrest because the general population wants the gas directed to domestic markets. The government now places controls on such projects. Except for the stranded gas fields located near the Donggi-Senora project, the cost analysis for all the evaluated stranded gas field clusters shown for Indonesia, Malaysia, and Australia (figs. 6 and 7) assumed that process trains would be added to existing LNG facilities or facilities under construction. The locations of these plants and distances to the Asian target markets are shown in table A3-1. Liquefaction plants located outside of North America with corresponding capacity ratings are listed in table A3-2. Table A3-3 shows location and capacity of liquefaction plants under construction in Southeast Asia and Oceania that could serve gas markets in Asia. New trains were assumed to be at a scale that was consistent with the plant. 


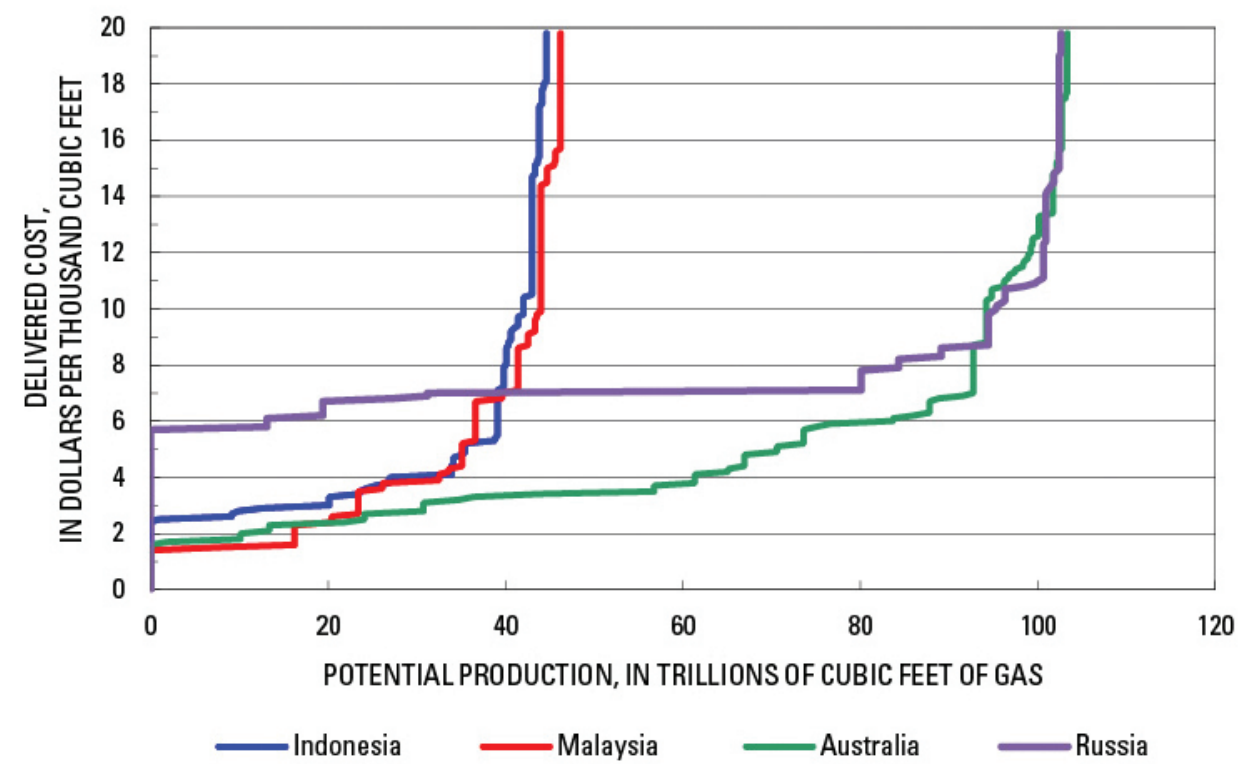

Figure 15. Graph showing estimated costs by region of developing, producing, and transporting stranded gas to coastal LNG plant locations. Curves show costs for Indonesia, Malaysia, Australia, and Russia. Cost estimates as of early 2008 and in constant 2008 dollars. Figure modified from Attanasi and Freeman (2012b).

Resource cost functions were developed for the stranded gas fields assigned to each LNG plant location. These functions were similar to those developed for the gas producers in the Atlantic Basin and north Africa. The Malaysia plant is in Bintulu (fig. 6). A Russian plant using gas from eastern Siberia is planned for Vladivostok (fig. 11). Indonesia and Australia have multiple plants (figs. 6 and 7). These functions were aggregated to the country level and are presented in figure 15. The shape and position of the curves reflect the numbers and sizes of the stranded gas fields. The cost functions show that at a cost of $\$ 3$ per MCF at the LNG plants, the economically recoverable resources are 31 TCF in Australia, 23 TCF in Malaysia, and 21 TCF in Indonesia. Given the common fiscal and economic assumptions imposed in this analysis, it will require $\$ 5.80$ per MCF to recover the full costs of developing, producing, and transporting gas from stranded fields located in the eastern Siberian basins to Vladivostok. Transportation from the stranded fields to Vladivostok accounts for about 80 percent of the cost of the initial tranche of gas. For Australia, Indonesia, and Malaysia, more than 90 percent of the gas in stranded fields evaluated was offshore, and so the transport costs to the coastal LNG location were small.

In contrast to the European market, the Asian market has fragmented demand centers that are not at all connected by pipelines. Consequently, the costs of delivering LNG to market were computed for specific regasification terminals in China, India, Japan, and South Korea. In table 15, the column labeled "First tranche LNG inlet cost" has the unit costs of developing, producing, and delivering the lowest cost tranche of gas assigned to each LNG complex to the trains initially added. The size of the tranche is the volume of gas required to operate the new train over a 25 -year period.

Additional trains at a given complex are assigned progressively higher cost resources. Table 16 shows the resource costs associated with developing, producing, and transporting stranded gas to the operating and planned LNG complexes listed. Excluding the gas supplying the planned Vladivostok plant, almost 90 percent of the cumulative gas can be delivered to LNG plants for less than $\$ 6$ per MCF. In table 15, the estimated lowest cost tranche of stranded gas from the basins in eastern Siberia delivered to Vladivostok is $\$ 5.80$ per MCF.

Tables 15 and 16 can be used to estimate the landed cost at any of the market locations for additional tranches from a particular supplier. For example, it is assumed that the expansion of LNG capacity at each supply node occurs by adding trains of the same size as listed in table 15 , which provides landed costs at market of the initial tranche of gas. Table 16 shows how much LNG plant process gas cost will increase as additional resources are committed when additional process trains are added. A sensitivity of the analysis shows that for every dollar of increase per MCF of gas at the LNG plant, the delivered cost will increase $\$ 1.16$ per MMBtu (based on a distance of 3,000 nmi to market). At Withnell Bay, the initial tranche of gas is $\$ 1.80$ and each additional train requires a commitment of $6.3 \mathrm{TCF}$. Table 16 shows that it would actually require $\$ 3.50$ per MCF to bring the extra gas needed to supply the additional train. The landed cost at Shanghai for the second tranche of gas using the stranded gas at Withnell Bay is about $\$ 10.58 \mathrm{MMBtu}$ (that is, $1.16 \times \$ 1.70+\$ 8.61=\$ 10.58$ ). 
Table 15. Delivered threshold prices of the first tranche of gas as liquefied natural gas (LNG) from stranded gas fields in Australia, Malaysia, Indonesia, and Russia to four Asian markets.

[The first tranche is the volume of stranded gas that must be produced to operate an additional train at the capacity shown for a 25-year period. MTY, millions of metric tons per year; TCF, trillions of cubic feet; \$MCF, dollars per thousand cubic feet in constant 2008 dollars; \$MMBtu, dollars per million British thermal units in constant 2008 dollars]

\begin{tabular}{|c|c|c|c|c|c|c|c|c|}
\hline \multirow[b]{2}{*}{$\begin{array}{r}\text { LNG complex } \\
\text { (figs. } 6,7,11 \text { ) }\end{array}$} & \multirow[b]{2}{*}{$\begin{array}{l}\text { Additional train } \\
\text { capacity } \\
\text { (MTY) }\end{array}$} & \multirow{2}{*}{$\begin{array}{l}\text { Volume } \\
\text { required to } \\
\text { operate train for } \\
25 \text { years } \\
\text { (TCF) }\end{array}$} & \multirow[b]{2}{*}{$\begin{array}{l}\text { First tranche } \\
\text { LNG inlet cost } \\
\text { (\$/MCF) }\end{array}$} & \multirow[b]{2}{*}{$\begin{array}{c}\text { Liquefaction } \\
\text { cost } \\
\text { (\$/MMBtu) }\end{array}$} & \multicolumn{4}{|c|}{ Delivered cost first tranche (\$/MMBtu) } \\
\hline & & & & & $\begin{array}{l}\text { Shanghai, } \\
\text { China }\end{array}$ & $\begin{array}{c}\text { Yokohama, } \\
\text { Japan }\end{array}$ & $\begin{array}{c}\text { Incheon, } \\
\text { South Korea }\end{array}$ & $\begin{array}{c}\text { Hazira, } \\
\text { India }\end{array}$ \\
\hline \multicolumn{9}{|c|}{ Australia (fig. 7) } \\
\hline Withnell Bay & 4.4 & 6.3 & 1.80 & 5.27 & 8.61 & 8.72 & 8.78 & 8.66 \\
\hline Browse (proposed) & 4.0 & 5.7 & 3.50 & 5.76 & 10.67 & 10.78 & 10.84 & 10.96 \\
\hline Darwin & 3.6 & 5.1 & 2.40 & 5.83 & 9.51 & 9.63 & 9.68 & 10.08 \\
\hline Gladstone & 4.0 & 5.7 & 3.30 & 5.73 & 10.79 & 10.68 & 10.97 & 11.55 \\
\hline \multicolumn{9}{|c|}{ Malaysia (fig. 6) } \\
\hline Bintulu & 3.4 & 4.8 & 1.50 & 4.83 & 7.22 & 7.45 & 7.38 & 7.70 \\
\hline \multicolumn{9}{|c|}{ Indonesia (fig. 6) } \\
\hline Blang Lancang & 1.6 & 2.3 & 5.30 & 5.23 & 11.73 & 12.01 & 11.91 & 11.49 \\
\hline Tangguh & 3.8 & 5.4 & 2.60 & 4.79 & 8.40 & 8.51 & 8.57 & 9.28 \\
\hline Donggi-Senoro & 2.1 & 3.0 & 3.40 & 6.09 & 10.49 & 10.62 & 10.66 & 11.28 \\
\hline Bontang & 2.8 & 4.0 & 4.10 & 4.16 & 9.26 & 9.40 & 9.43 & 9.84 \\
\hline \multicolumn{9}{|c|}{ Russia (fig. 11) } \\
\hline Vladivostok (proposed) & 6.0 & 8.5 & 5.80 & 6.23 & 12.57 & 12.55 & 12.54 & 14.45 \\
\hline
\end{tabular}


Table 16. Estimated cost of developing, producing, and transporting gas to various operating and planned LNG complexes.

[\$/MCF, dollars per thousand cubic feet in constant 2008 dollars; LNG, liquefied natural gas; TCF, trillions of cubic feet]

\begin{tabular}{|c|c|c|c|c|c|c|c|c|c|c|}
\hline \multirow{2}{*}{$\begin{array}{c}\text { Delivered } \\
\text { cost at transshipment } \\
\text { location } \\
\text { (\$/MCF) }\end{array}$} & \multicolumn{4}{|c|}{ Australia } & \multirow{2}{*}{$\begin{array}{c}\text { Malaysia } \\
\text { Bintulu } \\
\text { (TCF) }\end{array}$} & \multicolumn{4}{|c|}{ Indonesia } & \multirow{2}{*}{$\begin{array}{c}\text { Russia } \\
\begin{array}{c}\text { Vladivostok } \\
\text { (TCF) }\end{array}\end{array}$} \\
\hline & $\begin{array}{l}\text { Withnell Bay } \\
\text { (TCF) }\end{array}$ & $\begin{array}{c}\text { Browse } \\
\text { (TCF) }\end{array}$ & $\begin{array}{l}\text { Darwin } \\
\text { (TCF) }\end{array}$ & $\begin{array}{l}\text { Gladstone } \\
\text { (TCF) }\end{array}$ & & $\begin{array}{l}\text { Arun at Blang } \\
\text { Lancang } \\
\text { (TCF) }\end{array}$ & $\begin{array}{l}\text { Tangguh } \\
\text { (TCF) }\end{array}$ & $\begin{array}{l}\text { Donggi- } \\
\text { Senoro } \\
\text { (TCF) }\end{array}$ & $\begin{array}{l}\text { Bontang } \\
\text { (TCF) }\end{array}$ & \\
\hline 1.00 & 0.0 & 0.0 & 0.0 & 0.0 & 0.0 & 0.0 & 0.0 & 0.0 & 0.0 & 0.0 \\
\hline 1.50 & 0.0 & 0.0 & 0.0 & 0.0 & 7.7 & 0.0 & 0.0 & 0.0 & 0.0 & 0.0 \\
\hline 2.00 & 8.3 & 0.0 & 0.0 & 1.8 & 16.2 & 0.0 & 0.0 & 0.0 & 0.0 & 0.0 \\
\hline 2.50 & 11.6 & 0.0 & 8.4 & 4.1 & 20.4 & 0.0 & 0.8 & 0.0 & 0.0 & 0.0 \\
\hline 3.00 & 11.6 & 0.0 & 15.0 & 4.1 & 23.4 & 1.3 & 15.2 & 0.8 & 2.8 & 0.0 \\
\hline 3.50 & 15.6 & 12.8 & 22.5 & 5.8 & 23.4 & 1.3 & 15.2 & 4.3 & 2.8 & 0.0 \\
\hline 4.00 & 20.2 & 12.8 & 22.5 & 5.8 & 32.5 & 1.8 & 17.7 & 4.3 & 3.2 & 0.0 \\
\hline 4.50 & 25.8 & 12.8 & 22.5 & 5.8 & 35.1 & 1.8 & 17.7 & 4.3 & 10.3 & 0.0 \\
\hline 5.00 & 25.8 & 12.8 & 25.4 & 6.6 & 35.1 & 1.8 & 18.7 & 4.4 & 10.5 & 0.0 \\
\hline 5.50 & 25.8 & 12.8 & 28.4 & 6.6 & 36.6 & 3.3 & 19.6 & 4.4 & 11.8 & 0.0 \\
\hline 6.00 & 28.7 & 19.9 & 28.4 & 6.6 & 36.6 & 3.3 & 19.6 & 4.4 & 11.8 & 13.1 \\
\hline 6.50 & 31.9 & 19.9 & 29.4 & 6.6 & 36.6 & 3.3 & 19.6 & 4.4 & 11.8 & 19.4 \\
\hline 7.00 & 31.9 & 19.9 & 33.3 & 7.6 & 39.6 & 3.3 & 19.6 & 4.4 & 11.8 & 31.2 \\
\hline 7.50 & 31.9 & 19.9 & 33.3 & 7.6 & 41.4 & 3.3 & 19.6 & 4.4 & 12.5 & 80.1 \\
\hline 8.00 & 31.9 & 19.9 & 33.3 & 7.6 & 41.4 & 3.3 & 19.6 & 4.4 & 12.7 & 84.3 \\
\hline 8.50 & 31.9 & 19.9 & 33.3 & 7.6 & 41.4 & 3.4 & 19.6 & 4.4 & 12.7 & 89.1 \\
\hline 9.00 & 31.9 & 21.4 & 33.3 & 7.6 & 42.5 & 3.7 & 19.6 & 4.4 & 12.9 & 94.4 \\
\hline 9.50 & 31.9 & 21.4 & 33.3 & 7.6 & 43.3 & 3.7 & 19.6 & 4.4 & 13.7 & 94.4 \\
\hline 10.00 & 31.9 & 21.4 & 33.3 & 7.6 & 44.0 & 3.7 & 19.6 & 4.4 & 14.3 & 94.9 \\
\hline 10.50 & 32.5 & 21.4 & 33.3 & 7.6 & 44.0 & 3.7 & 19.6 & 4.4 & 15.3 & 96.3 \\
\hline 11.00 & 33.9 & 21.4 & 33.3 & 7.6 & 44.0 & 3.7 & 19.6 & 4.4 & 15.3 & 99.7 \\
\hline 11.50 & 36.0 & 21.4 & 33.3 & 7.6 & 44.0 & 3.7 & 19.6 & 4.4 & 15.3 & 100.6 \\
\hline 12.00 & 36.3 & 21.4 & 33.7 & 7.8 & 44.0 & 3.7 & 19.6 & 4.4 & 15.3 & 100.6 \\
\hline 12.50 & 36.3 & 21.4 & 33.7 & 8.0 & 44.0 & 3.7 & 19.6 & 4.4 & 15.3 & 100.9 \\
\hline 13.00 & 37.0 & 21.4 & 33.7 & 8.0 & 44.0 & 3.7 & 19.6 & 4.4 & 15.3 & 100.9 \\
\hline 13.50 & 38.0 & 22.0 & 33.7 & 8.0 & 44.0 & 3.7 & 19.6 & 4.4 & 15.3 & 100.9 \\
\hline 14.00 & 38.0 & 22.0 & 33.7 & 8.0 & 44.0 & 3.7 & 19.6 & 4.4 & 15.3 & 100.9 \\
\hline 14.50 & 38.0 & 22.0 & 33.7 & 8.0 & 44.7 & 3.7 & 19.6 & 4.4 & 15.3 & 101.5 \\
\hline 15.00 & 38.0 & 22.0 & 34.1 & 8.0 & 44.7 & 3.7 & 19.6 & 4.4 & 15.6 & 102.1 \\
\hline 15.50 & 38.0 & 22.2 & 34.1 & 8.0 & 45.6 & 3.7 & 19.6 & 4.4 & 16.1 & 102.4 \\
\hline 16.00 & 38.0 & 22.2 & 34.5 & 8.0 & 46.2 & 3.7 & 19.6 & 4.4 & 16.1 & 102.4 \\
\hline
\end{tabular}




\section{Implications for Meeting Asia's Future Demand for Imported Gas}

The stranded gas resources evaluated in Southeast Asia and Australia amount to 215 TCF. About 170 TCF of this gas can be delivered to markets in Asia at landed costs that are within the landed price ranges of historical experience. Average annual prices for Japan from 2009 to 2011 ranged from $\$ 9.06$ to $\$ 14.73$ per MMTBU (BP, 2012). Based on data from figure 14, at a delivered cost of $\$ 14$ per MMBTU (almost $\$ 15$ per MCF) to Shanghai, there is another 101 TCF in stranded fields in basins of eastern Siberia that could be commercially developed, and about 93 TCF from the West Siberian Basin. The distance from Turkmenistan's Amu Darya fields to Uzhhorod, Ukraine, is about 2,300 mi, whereas the distance to Shanghai is just over 3,500 mi. However, the market prospects for commercial development of central Asia's stranded gas favor Asia, and in particular, China, because the gas transportation infrastructure is already in operation. Furthermore, the landed costs of Turkmeni gas in Shanghai are competitive with costs of LNG and gas from the basins in eastern Siberia. The additional gas could amount to another 240 TCF even if some of the Turkmeni stranded gas is marketed to Europe. The gas in stranded gas fields that could be commercially accessible to these four markets in Asia from the West Siberian Basin, the eastern Siberian basins, central Asia, and Southeast Asia and Australia is just short of $600 \mathrm{TCF}$, a volume that substantially would meet the estimated alternative demand scenario of $625 \mathrm{TCF}$, computed with the data from table 9 and the procedure described in footnote 11.

Importers of gas in Asia have the same concerns about supply security as importers in Europe and are likely to opt for diversity of suppliers rather than to choose the single lowest cost supplier. Japan and South Korea have large industrial bases but small domestic gas resources. Conventional gas resources in China and India fall short of domestic consumption. Many of the entities purchasing pipeline gas and LNG are state-controlled companies that resell gas to local distribution and power companies. These may be units of national oil and gas companies or semi-governmental utilities. The units frequently purchase equity positions in the LNG facilities, and their governments may subsidize the financing of part of the LNG project. The establishment of equity positions, assistance in financing, and the desire of the purchasers for long-term contracts are efforts to mitigate supply risks. In many cases, the government-controlled purchasing entities are given exclusive rights to sell the gas by the importing country. With a captive domestic market, these entities face virtually no market risk. For the international oil and gas firm operating the LNG project, such an arrangement may assure high utilization of the plant, mitigate risks, and provide below-market financing.

During the last few years, large conventional nonassociated gas discoveries in offshore Mozambique and Tanzania in east Africa have been announced. Wood Mackenzie Research and Consulting (2012) estimated that 100 TCF of natural gas has been found and another 95 TCF is still undiscovered in these offshore areas. The development of these gas resources will be delayed because these countries currently lack physical infrastructure. The governments must also develop a legal framework and regulatory institutions for executing such large, high-risk projects. It is expected that Asia would be the primary gas export market because of proximity.

\section{Conclusions and Implications}

The data and the cost analysis presented here suggest that for the European market and the markets examined in Asia, the development of stranded gas provides a way to meet projected demands for gas imports for the period from 2020 to 2040 . Although this is a reconnaissance-type appraisal, it is based on volumes of gas that are associated with individual identified fields. Individual field data were carefully examined. Some fields were not evaluated because it appeared that the gas would likely be held off the export market. Indonesia's Natuna D-alpha field, having roughly 40 TCF of natural gas and 100 TCF of carbon dioxide, was not evaluated because of questions about applicability of current carbon sequestration technology. Most of the evaluated stranded gas can be produced and delivered to markets at costs comparable to historical prices. Moreover, the associated volumes of gas are sufficient to provide an interim supply while additional technologies are developed to unlock gas diffused in shale and hydrates or while countries transition to making a greater use of renewable energy sources.

Growth in natural gas demand could be accelerated if governments provided economic incentives to reduce carbon dioxide emissions or if governments reduced the number of nuclear powerplants. The import demand projections for Europe and the Asian markets (U.S. Energy Information Administration, 2011b) predict that only relatively small volumes of gas from shale will be produced during the period from 2020 to 2040, despite the large resources assigned by Advanced Resources International Incorporated (U.S. Energy Information Administration, 2011c). In addition to shale resources, there are other sources of gas that can significantly augment world supplies. The stranded gas in the Middle East was not included in the analysis. Qatar leads the world in installed LNG capacity (table A3-2) and has the resources to sustain and expand supplies to Europe and Asia. Iran's gas in stranded gas fields amounts to $214 \mathrm{TCF}$.

The LNG industry was started as an effort by gas producers to monetize stranded gas. The emergence of the global LNG market provides the gas purchasers and suppliers a margin of flexibility that the pipeline deliveries of gas cannot offer. LNG 
contract provisions that now permit redirection of cargoes have been important to Japanese LNG purchasers in the aftermath of the March 11, 2011, earthquake and the related tsunami that caused the failure of the Fukushima Dai-ichi nuclear power station. The flexibility of destinations of LNG shipments has contributed to the breakdown of entry barriers in some markets. The growth of LNG supplies has also challenged producers attempting to monopolize certain markets. A number of offshore or floating regasification terminals are now in operation where LNG tankers unload cargoes. The use of floating regasification reduces the port infrastructure required for receiving LNG and gives buyers the opportunity to purchase LNG where port facilities are inadequate.

Floating liquefaction plants are yet another technology extending LNG into new situations. These facilities have been designed but are not yet deployed. Commercial floating LNG facilities could expand the number of stranded gas fields that could be commercially developed by reducing the minimum offshore field sizes considered for LNG development. The floating liquefaction facility could be relocated and reused as gas fields were depleted. Developers argue that floating facilities could offer significant project cost reductions because the onshore plant, its site, pipeline infrastructure, and tanker loading and storage facilities would not be needed.

\section{Acknowledgments}

The authors thank U.S. Geological Survey colleagues Robert Milici, Ricardo Olea, and Susan Tewalt for reviews, Elizabeth Good for editing, and Cathy Knutson for layout.

\section{References Cited}

Aibing, Guo, 2012, China doubling gas use makes ex-clothing retailer [China Gas Holdings Ltd.] target: Bloomberg, May 16, 2012, available at http://www.bloomberg.com/news/2012-05-16/china-doubling-gas-use-makes-ex-clothing-retailer-target. html.

Alexander's Gas and Oil Connections, 2004, New gas pipeline linking Libya and Italy opened: Alexander's Gas and Oil Connections, October 8, 2004, accessed December 22, 2009, at http://www.gasandoil.com/GOC/news/nte44584.htm.

Algeria Ministry of Energy and Mining (Ministère de l'Energie et des Mines), 2009, Project GALSI / Gazoduc Algérie - Italie via la Sardaigne [Project GALSI Web site]: Algeria Ministry of Energy and Mining Web site, accessed December 22, 2009, at http://www.mem-algeria.org/actu/comn/galsi.htm.

Andresen, Tino, and Shiryaevskaya, Anna, 2012, EON raises profit forecast after Gazprom gas price deal: Bloomberg, July 3, 2012, accessed July 3, 2012, at http://www.bloomberg.com/news/2012-07-03/eon-raises-profit-forecast-after-gazpromgas-price-deal.html.

Attanasi, E.D., and Freeman, P.A., 2010, A survey of stranded gas resources and estimates of development and production costs, in Global volatility—Surviving and thriving - SPE Hydrocarbon Economics and Evaluation Symposium, 8-9 March 2010, Dallas, Texas, USA, Proceedings: Richardson, Tex., Society of Petroleum Engineers, SPE paper 130089-MS, 19 p., DOI:10.2118/130089-MS.

Attanasi, E.D., and Freeman, P.A., 2011, Survey of stranded gas and delivered costs to Europe of selected gas resources: SPE Economics and Management, v. 3, no. 3 (July), p. 149-162, DOI:10.2118/130089-PA.

Attanasi, E.D., and Freeman, P.A., 2012a, Role of stranded gas from central Asia and Russia in meeting Europe's import demand for gas: Natural Resources Research, v. 21, no. 2, p. 193-220, DOI:10.1007/s11053-012-9172-6. (Figure 7 of this article was replaced by an update in September 2012 in Natural Resources Research, v. 21, no. 3, p. 411, DOI:10.1007/s11053012-9178-0.)

Attanasi, E.D., and Freeman, P.A., 2012b, Role of stranded gas from central Asia, Russia, Southeast Asia, and Australia in meeting Asia's future demand for gas imports, in Impact of technology and stakeholder challenges-SPE Hydrocarbon Economics and Evaluation Symposium, 23-25 September 2012, Calgary, Alberta, Canada, Proceedings: Richardson, Tex., Society of Petroleum Engineers, SPE paper 162870-MS, 37 p., DOI:10.2118/162870-MS. 
BP, 2006, SCP [South Caucasus Pipeline] commissioning commences: BP press release of June 1, 2006, accessed August 1, 2011, at http://www.bp.com/genericarticle.do? categoryId $=9006615 \&$ contentId $=7018471$.

BP, 2009, BP statistical review of world energy 2009: London, BP, 45 p.

BP, 2010, BP statistical review of world energy 2010: London, BP, 50 p.

BP, 2011a, BP statistical review of world energy 2011: London, BP, 49 p., accessed June 16, 2011, at http://www.bp.com/ sectionbodycopy.do? categoryId $=7500 \&$ contentId $=7068481$. [No longer accessible.]

BP, 2011b, South Caucasus pipeline: BP Web site, accessed August 1, 2011, at http://www.bp.com/sectiongenericarticle.do? cate goryId $=9006670 \&$ contentId $=7015095$.

BP, 2012, BP statistical review of world energy June 2012: London, BP, 45 p., accessed August 31, 2012, at http://www.bp.com/ statisticalreview/.

China National Petroleum Corporation (CNPC), 2012, CNPC, our businesses - Interactive version — Oil \& gas pipelines: CNPC Web site, accessed February 29, 2012, at http://www.cnpc.com.cn/en/aboutcnpc/ourbusinesses/Our_Businesses_b.htm.

China-Wire, 2008, China launches 2nd west-to-east gas pipeline project: China-Wire, February 22, 2008, accessed June 15, 2012, at http://china-wire.org/? $p=181$.

Deutch, John, 2011, The good news about gas: Foreign Affairs, January/February, p. 82-93.

Durr, Charles, Coyle, David, Hill, Don, and Smith, Sharon, 2005, LNG technology for the commercially minded, in Gastech 2005, 21st International Conference and Exhibition for the LNG, LPG and Natural Gas Industries, 14-17 March 2005, Bilbao, Spain, Proceedings: London, Gastech, 14 p., accessed June 8, 2012, at http://www.kbr.com/Newsroom/Publications/ technical-papers/LNG-Technology-for-the-Commercially-Minded.pdf.

Energy and Environmental Analysis, Inc., 1988, Costs for LNG imports into the United States: Washington, D.C., Gas Research Institute, Strategic Analysis and Energy Forecasting Division, [Technical Report,] 38 p. (Prepared under GRI contract \#5087-800-1474, August 1988.)

Ericson, R.E., 2009, Eurasian network of natural gas pipelines-The political economy of network interdependence: Eurasian Geography and Economics, v. 50, no. 1, p. 28-57, DOI:10.2747/1539-7216.50.1.28.

ESRI, 2010, World physical map: Redlands, Calif., ESRI, http://www.esri.com/software/arcgis/arcgisonline/standard-maps.html. [No longer accessible.]

ESRI, 2012, World physical map: Redlands, Calif., ESRI, accessed August 7, 2012, at http://www.esri.com/software/arcgis/ arcgis-online-map-and-geoservices/map-services.

Flower, Andy, 2008, Natural gas from the Middle East, chap. 8 of Stern, Jonathan, ed., Natural gas in Asia (2d ed.): Oxford, U.K., Oxford University Press, p. 330-378.

For-UA, 2011, Ukraine began the modernization of gas transport system: For-UA News from Ukraine Web site, accessed July 27, 2011, at http://for-ua.org/ukraine/2011/07/19/101439.html.

Fridley, David, 2008, Natural gas in China, chap. 2 of Stern, Jonathan, ed., Natural gas in Asia (2d ed.): Oxford, U.K., Oxford University Press, p. 7-65.

Gas Infrastructure Europe, 2011, Gas LNG Europe-LNG map: Brussels, Gas Infrastructure Europe, scale 1:8,000,000, Web site at http://www.gie.eu/index.php/maps-data. [Web site functional, map no longer available.]

Gazprom, 2011a, Blue Stream: Gazprom Web site, accessed August 1, 2011, at http://www.gazprom.com/production/projects/ pipelines/blue-stream/.

Gazprom, 2011b, South Stream: Gazprom Web site, accessed August 1, 2011, at http://www.gazprom.com/production/projects/ pipelines/south-stream/.

Gazprom, 2012, Eastern gas program: Gazprom Web site, accessed May 24, 2012, at http://www.gazprom.com/about/production/ projects/east-program/. 
Gray, L.A., Hong, W., and Naxin, M., 2003, Chinese gas pipeline design, contractors target full start-up for 2004: Oil and Gas Journal, v. 101, no. 21, p. 54-59.

Gurt, Marat, 2011, Update 2-Gas field growth fuels Turkmen energy ambitions: Reuters Business and Financial News, October 11, 2011, accessed October 30, 2011, at http://www.reuters.com/article/2011/10/11/gas-turkmenistanidUSL5E7LB1VY20111011.

Hayes, M.H., 2006a, Flexible LNG supply and gas market integration-A simulation approach for valuing the market arbitrage option, in 23rd World Gas Conference, Amsterdam, 2006, Proceedings: International Gas Union, 17 p., accessed October 17, 2009, at http://www.igu.org/html/wgc2006/pdf/paper/add11335.pdf.

Hayes, M.H., 2006b, The Transmed and Maghreb projects—Gas to Europe from north Africa, in Victor, D.G., Jaffe, A.M., and Hayes, M.H., eds., Natural gas and geopolitics-From 1970 to 2040: Cambridge, U.K., Cambridge University Press, p. $49-90$.

Herbert, J.H., and Kreil, Erik, 1996, US natural gas markets-How efficient are they?: Energy Policy, v. 24, no. 1, p. 1-5, DOI:10.1016/0301-4215(95)00145-X.

IHS Inc., 2007, European gas and power markets' quest for supply diversity and security: Powerpoint presentation given April 17, 2007, by Cynthia Poynter.

IHS Inc., 2008, QUE\$TOR Petroleum Field Development and Production Cost software, ver. 9.6: Englewood, Colo., IHS Inc.

IHS Inc., 2009, International Petroleum Exploration and Production database: Englewood, Colo., IHS Inc.

Inajima, Tsuyoshi, and Okada, Yuji, 2011, Nuclear promotion dropped in Japan energy policy after Fukushima: Bloomberg News, October 27, 2011, http://www.bloomberg.com/news/2011-10-28/nuclear-promotion-dropped-in-japan-energy-policyafter-fukushima.html.

International Energy Agency (IEA), 2011, Natural gas information, 2011: Paris, IEA, 566 p.

International Gas Union (IGU), 2011, Wholesale gas price formation-A global review of drivers and regional trends: Oslo, Norway, International Gas Union, 68 p., accessed July 31, 2012, at http://www.igu.org/igu-publications.

International Group of Liquefied Natural Gas Importers (GIIGNL), 2011, The LNG industry in 2011: Paris, GIIGNL, 32 p., accessed September 25, 2012, at http://www.giignl.org/fileadmin/user_upload/pdf/A_PUBLIC_INFORMATION/LNG_ Industry/GIIGNL_The_LNG_Industry_2011.pdf.

Ledesma, David, 2008, South east Asian and Australian supply to Asia, chap. 7 of Stern, Jonathan, ed., Natural gas in Asia (2d ed.): Oxford, U.K., Oxford University Press, p. 279-329.

Massachusetts Institute of Technology, 2011, The future of natural gas: Cambridge, Mass., Massachusetts Institute of Technology, 170 p., accessed October 22, 2012, at http://web.mit.edu/mitei/research/studies/natural-gas-2011.shtml.

MEDGAZ, 2009, [Project description]: MEDGAZ Web site, accessed December 22, 2009, at http://www.medgaz.com/medgaz/ pages/index-eng.htm.

Melling, A.J., 2010, Natural gas pricing and its future-Europe as the battleground: Washington, D.C., Carnegie Endowment for International Peace, 136 p., accessed July 15, 2011, at http://www.carnegieendowment.org/files/gas_pricing_europe.pdf.

Mufson, Steven, 2011, Germany to shut down nuclear plants by 2022-Decision in aftermath of crisis in Japan is a turnaround for Merkel: Washington, D.C., The Washington Post, May 31, 2011, p. 1.

Nord Stream, 2011, Nord Stream Web site: accessed August 1, 2011, at http://www.nord-stream.com/en/.

Pickl, Matthias, and Wirl, Franz, 2010, Enhancing the EU's energy supply security-An evaluation of the Nabucco Project and an introduction to its open season capacity allocation process: Zeitschrift für Energiewirtschaft, v. 34, no. 3, p. 153-161, DOI:10.1007/s12398-010-0017-x.

Pirani, Simon, ed., 2009, Russian and CIS gas markets and their impact on Europe: Oxford, U.K., Oxford University Press, $487 \mathrm{p}$. 
Rogers, H.V., 2012, The impact of a globalising market on future European gas supply and pricing-The importance of Asian demand and North American supply: Oxford, U.K., Oxford Institute for Energy Studies, NG 59, 88 p., accessed August 3, 2012, at http://www.oxfordenergy.org/2012/01/the-impact-of-a-globalising-market-on-future-european-gas-supply-andpricing-the-importance-of-asian-demand-and-north-american-supply/.

Sagers, M.J., 2007, Developments in Russian gas production since 1998—Russia's evolving gas supply strategy: Eurasian Geography and Economics, v. 48, no. 6, p. 651-698, DOI:10.2747/1539-7216.48.6.651.

Siliverstovs, Boriss, Hégaret, Guillaume, Neumann, Anne, and von Hirschhausen, Christian, 2005, International market integration for natural gas? A cointegration analysis of prices in Europe, North America and Japan: Energy Economics, v. 27, no. 4, p. 603-615, DOI:10.1016/j.eneco.2005.03.002.

Smith, C.E., 2011, Special report-Pipeline construction plans continue slide despite growth in natural gas: Oil and Gas Journal, v. 109, no. 6, February 7, 2011, accessed August 24, 2012, at http://www.ogj.com/articles/print/volume-109/issue-6/ transportation/special-report-pipeline-construction-plans-continue-slide-despite._printArticle.html.

Socor, Vladimir, 2012, China to increase central Asian gas imports through multiple pipelines: Eurasia Daily Monitor, v. 9 , no. 152, August 9, 2012, accessed August 24, 2012, at http://www.jamestown.org/single/?no_cache $=1 \& t x \_t t n e w s \% 5 B t t_{-}$ news $\% 5 D=39751$.

Statoil, 2012, Statfjord late life: Statoil Web site, accessed September 26, 2012, at http://www.statoil.com/en/OurOperations/ ExplorationProd/ncs/statfjord/StatfjordLateLife/Pages/default.aspx.

Stern, Jonathan, and Rogers, Howard, 2011, The transition to hub-based gas pricing in continental Europe: Oxford, U.K., Oxford Institute for Energy Studies, NG 49, 41 p., accessed August 9, 2012, at http://www.oxfordenergy. org/? $=$ The + transition + to + hub-based + gas + pricing + in + continental + Europe .

True, W.R., 2012, 2012 LNG world trade [map insert]: Tulsa, Okla., PennWell, [map inserted in] Oil and Gas Journal, v. 110, no. 2, February 6, 2012.

U.S. Energy Information Administration (EIA), 2009a, Dry natural gas consumption - International energy statistics table: U.S. Energy Information Administration Web page, accessed September 30, 2009, at http://tonto.eia.doe.gov/cfapps/ ipdbproject/IEDIndex3.cfm?tid=3\&pid=26\&aid=2.

U.S. Energy Information Administration (EIA), 2009b, Imports of dry natural gas - International energy statistics table: U.S. Energy Information Administration Web page, accessed September 30, 2009, at http://tonto.eia.doe.gov/cfapps/ ipdbproject/IEDIndex3.cfm?tid=3\&pid=26\&aid=3.

U.S. Energy Information Administration (EIA), 2009c, U.S. crude oil, natural gas, and natural gas liquids reserves—2007 annual report: U.S. Energy Information Administration [Report] DOE/EIA-0216(2007), variously paged [145 p.], accessed September 30,2009, at http://www.eia.doe.gov/pub/oil_gas/natural_gas/data_publications/crude_oil_natural_gas_reserves/ historical/2007/cr2007.html.

U.S. Energy Information Administration (EIA), 2011a, Indonesia (update May 2011): U.S. Energy Information Administration Country Analysis Brief, 9 p., accessed February 23, 2012, at http://www.eia.gov/EMEU/cabs/Indonesia/pdf.pdf.

U.S. Energy Information Administration (EIA), 2011b, International energy outlook 2011: U.S. Energy Information Administration [Report] DOE/EIA-0484(2011), 292 p., available at $h t t p: / / w w w . e i a . g o v / f o r e c a s t s / i e o / p d f / 0484(2011) . p d f$.

U.S. Energy Information Administration (EIA), 2011c, World shale gas resources-An initial assessment of 14 regions outside the United States: Washington, D.C., U.S. Energy Information Administration, variously paged [365 p.], available at http://www.eia.gov/analysis/studies/worldshalegas/pdf/fullreport.pdf.

U.S. Energy Information Administration (EIA), 2012, Iran (update February 2012): U.S. Energy Information Administration Country Analysis Brief, 13 p., accessed September 26, 2012, at http://www.eia.gov/EMEU/cabs/Iran/pdf.pdf.

U.S. Geological Survey World Energy Assessment Team, 2000, U.S. Geological Survey world petroleum assessment 2000-Description and results: U.S. Geological Survey Digital Data Series DDS-60, 4 CD-ROMs. (Also available at http://pubs.usgs.gov/dds/dds-060/.) 
Volkov, Dmitry, Gulen, Gurcan, Foss, Michelle, and Markaryan, Ruzanna, 2009, Gazprom pipeline gas remains key to Europe: Oil and Gas Journal, v. 107, no. 16, p. 53-56.

Wolfram, Catherine, Shelef, Orie, and Gertler, Paul, 2012, How will energy demand develop in the developing world?: Journal of Economic Perspectives, v. 26, no. 1, p. 119-138.

Wood Mackenzie Research and Consulting, 2012, East Africa faces technical and commercial challenges to bring 100tcf of discovered gas to market: Wood Mackenzie press release, August 22, 2012, accessed September 3, 2012, at http://www.woodmacresearch.com/cgi-bin/wmprod/portal/corp/corpPressDetailOpen.jsp? pass=10742819.

Woodside Energy, 2012, Browse LNG development: Woodside Energy Fact Sheet, 2 p., accessed August 31, 2012, at http://www.woodside.com.au/Our-Business/Browse/publications/Fact\%20Sheets/

Browse\%20LNG\%20Development\%20overview\%20factsheet\%20May\%202012.pdf.

Yenikeyeff, S.M., 2008, Kazakhstan's gas_-Export markets and export routes: Oxford, U.K., Oxford Institute for Energy Studies, NG 25, 80 p., available at http://www.oxfordenergy.org/2008/11/kazakhstan's-gas-export-markets-and-export-routes/. 


\section{Appendix 1. Stranded Gas Resources in the Middle East}

\section{Distribution of Stranded Gas Resources}

Figure 8 shows the locations of the clusters of stranded gas fields in the Middle East. Of the 303 TCF of the Middle East stranded gas in gas fields shown in table 2, Iran accounts for 214 TCF, or 71 percent of the total. ${ }^{1}$ Table A1-1 shows stranded gas in gas fields and stranded gas in oil fields by country for the Middle East. In 2011, Iran, Israel, Kuwait, Oman, and the United Arab Emirates (UAE) imported natural gas (BP, 2012). Countries having stranded gas fields that have dedicated their resources to domestic use are Israel (3 TCF), Syria (4 TCF), and Kuwait (10 TCF). Table A1-2 shows the field size distribution of the stranded gas fields for Iran, Iraq, Saudi Arabia, the UAE, Oman, and Yemen. The tables show Iran accounting for the largest stranded fields and the most stranded gas in all the Middle East. Well over 90 percent of Iran's stranded gas is in large fields. Gas fields reported in the IHS International Petroleum Exploration and Production database (IHS Inc., 2009) for Iraq, Saudi Arabia, the UAE, Oman, and Yemen that were classified as stranded were all smaller than 6.14 TCF.

The volume of stranded associated gas in oil fields is greater than the volume of gas in stranded gas fields. For the oilexporting countries with large oil reserves, there is little incentive in terms of generating new revenues to explore and develop natural gas. Furthermore, for much of the exploration history, natural gas was not considered an economic commodity. Consequently, in the cases of Iraq and Saudi Arabia, for example, nonassociated gas reserves may increase when those governments direct exploration to target conventional gas prospects. Some of the nonassociated gas listed might be in low-permeability formations or might have significant hydrogen sulfide contamination, which requires the application of sophisticated production technology only available at high cost (Flower, 2008).

\section{Prospects for Expanded Gas Exports}

Abu Dhabi of the UAE, Qatar, Oman, and Yemen currently export natural gas as LNG. The export of LNG from Abu Dhabi started in the 1970s. The Japanese utility Tokyo Electric Power Company (TEPCO) contracted to buy the liquefaction plant's entire initial output and its expanded output (1994) when an additional train was added. The plant initially used associated gas, which is a byproduct from oil production. Abu Dhabi's oil production, however, varies with the allotments assigned to it by the Organization of the Petroleum Exporting Countries (OPEC) because of its member status. Abu Dhabi imports pipeline gas from Qatar to assure that the LNG plants are utilized to meet their sales commitments (Flower, 2008). The Yemen liquefaction plant, with a capacity of 6.7 MTY, started operation in 2009 with South Korea and the United States as its primary initial buyers. The magnitude of proven reserves and identified stranded gas will not support further plant expansion (Flower, 2008). The Oman LNG plant complex started operation in September 2000 and now has three trains with a total capacity of 10.7 MTY (see table A3-2).

Qatar is the world's leading LNG exporter. North field accounts for nearly all of Qatar's nonassociated gas. However, in 2005, Qatar announced a moratorium on new proposals that would expand gas production from North field but permitted completion of projects that had already been authorized (Flower, 2008). The purpose of the moratorium was to allow the Qatari authorities to study the performance of the field in order to determine whether the field is suffering damage from overproduction These studies will not be completed until after 2012, and then this additional information will be used to evaluate new development proposals.

Although Iran has significant volumes of gas in stranded gas fields, it imports pipeline gas from Azerbaijan and Turkmenistan to supply users near the Caspian instead of transporting gas from its Zagros Fold Belt over the mountains. Iran's domestic use is growing rapidly as it uses gas as a fuel and to maintain reservoir pressures in depleting oil fields. Nonetheless, Iran also seeks export markets for gas in its stranded gas fields. These efforts have been hindered by the economic sanctions imposed in response to Iran's nuclear program (U.S. Energy Information Administration, 2012).

In summary, while the long-term prospects for additional conventional gas supplies from the Middle East are promising, there are a number of barriers to expansion in the next 20 years. Much of the gas listed as reserve is associated gas and is used

\footnotetext{
${ }^{1}$ The Middle East stranded gas total excludes Iran's South Pars field ( $\sim 360$ TCF) and Qatar's North field ( 900 TCF), which are parts of the same field. This single gas field is also thought to hold 9 billion barrels of recoverable condensate in the Iranian portion and 10 billion barrels of recoverable condensate in the Qatari portion. The values of the condensate produced exceed the netback cash flows from gas sales.
} 
to either prolong the life of oil fields or serve domestic fuel demands such as for electricity generation and water desalinization. The available nonassociated gas in some countries is used for feedstock in export-oriented petrochemical industries. The international sanctions imposed on Iran and the political tensions throughout the region have discouraged new investment.

Table A1-1. Volumes of remaining recoverable stranded natural gas onshore and offshore in Middle East oil and gas fields by country.

[Gas volumes are in trillions of cubic feet (TCF). Field data through the end of 2008 are from IHS Inc. (2009). Dash (-), data not available. Numbers may not add up due to rounding]

\begin{tabular}{|c|c|c|c|c|c|c|}
\hline \multirow{2}{*}{ Country ${ }^{1}$} & \multicolumn{3}{|c|}{ Gas in gas fields } & \multicolumn{3}{|c|}{ Gas in oil fields } \\
\hline & Onshore & Offshore & Total gas & Onshore & Offshore & Total gas \\
\hline Israel & - & 3 & 3 & - & - & - \\
\hline Iran & 123 & 92 & 215 & 265 & 30 & 295 \\
\hline Syria & 4 & 0 & 4 & 3 & - & 3 \\
\hline Iraq & 13 & 0 & 13 & 77 & - & 77 \\
\hline Kuwait & 10 & - & 10 & 33 & 5 & 38 \\
\hline Saudi Arabia & 21 & - & 21 & 83 & 37 & 119 \\
\hline Qatar & - & - & - & - & 13 & 13 \\
\hline United Arab Emirates & 3 & 7 & 10 & 10 & 13 & 24 \\
\hline Oman & 20 & 0 & 20 & 9 & 0 & 9 \\
\hline Yemen & 8 & - & 8 & 6 & - & 6 \\
\hline Middle East total & 202 & 102 & 304 & 486 & 98 & 584 \\
\hline
\end{tabular}

${ }^{1}$ Turkey is not shown in this table because stranded gas volumes are less than $1 \mathrm{TCF}$. 
Table A1-2. Distribution of gas by field size category for stranded gas in gas fields in Iran, Iraq, Saudi Arabia, the United Arab Emirates, Oman, and Yemen.

[Field data current through the end of 2008 are from IHS Inc. (2009). Country totals here differ slightly from those in table A1-1 because the minimum field size in this table is 0.048 TCF. Israel, Syria, Kuwait, and Qatar are not included in this table because the volumes of stranded gas reported are small relative to domestic demand, and so exports are unlikely. TCF, trillions of cubic feet; BCF, billions of cubic feet]

\begin{tabular}{|c|c|c|c|c|}
\hline $\begin{array}{l}\text { Gas field size } \\
\text { class range } \\
\text { (TCF) }\end{array}$ & Number of fields & $\begin{array}{l}\text { Cumulative } \\
\text { percentage of } \\
\text { fields }\end{array}$ & $\begin{array}{l}\text { Volume in size } \\
\text { class } \\
\text { (BCF) }\end{array}$ & $\begin{array}{c}\text { Cumulative } \\
\text { percentage of gas } \\
\text { volume }\end{array}$ \\
\hline \multicolumn{5}{|c|}{ Iran } \\
\hline$>49.2$ & 0 & 0.0 & 0 & 0.0 \\
\hline $24.6-49.2$ & 3 & 7.1 & 108,000 & 50.4 \\
\hline $12.3-24.6$ & 2 & 11.9 & 34,301 & 66.4 \\
\hline $6.14-12.3$ & 2 & 16.7 & 14,715 & 73.2 \\
\hline $3.07-6.14$ & 8 & 35.7 & 33,997 & 89.1 \\
\hline $1.54-3.07$ & 4 & 45.2 & 8,592 & 93.1 \\
\hline $0.768-1.54$ & 9 & 66.7 & 9,818 & 97.7 \\
\hline $0.384-0.768$ & 5 & 78.6 & 2,999 & 99.1 \\
\hline $0.192-0.384$ & 5 & 90.5 & 1,436 & 99.8 \\
\hline $0.096-0.192$ & 4 & 100.0 & 500 & 100.0 \\
\hline $0.048-0.096$ & 0 & 100.0 & 0 & 100.0 \\
\hline Total & 42 & & 214,358 & \\
\hline \multicolumn{5}{|c|}{ Iraq } \\
\hline$>49.2$ & 0 & 0.0 & 0 & 0.0 \\
\hline $24.6-49.2$ & 0 & 0.0 & 0 & 0.0 \\
\hline $12.3-24.6$ & 0 & 0.0 & 0 & 0.0 \\
\hline $6.14-12.3$ & 0 & 0.0 & 0 & 0.0 \\
\hline $3.07-6.14$ & 1 & 12.5 & 3,300 & 25.5 \\
\hline $1.54-3.07$ & 3 & 50.0 & 6,400 & 74.8 \\
\hline $0.768-1.54$ & 3 & 87.5 & 3,200 & 99.5 \\
\hline $0.384-0.768$ & 0 & 87.5 & 0 & 99.5 \\
\hline $0.192-0.384$ & 0 & 87.5 & 0 & 99.5 \\
\hline $0.096-0.192$ & 0 & 87.5 & 0 & 99.5 \\
\hline $0.048-0.096$ & 1 & 100.0 & 65 & 100.0 \\
\hline Total & 8 & & 12,965 & \\
\hline \multicolumn{5}{|c|}{ Saudi Arabia } \\
\hline$>49.2$ & 0 & 0.0 & 0 & 0.0 \\
\hline $24.6-49.2$ & 0 & 0.0 & 0 & 0.0 \\
\hline $12.3-24.6$ & 0 & 0.0 & 0 & 0.0 \\
\hline $6.14-12.3$ & 0 & 0.0 & 0 & 0.0 \\
\hline $3.07-6.14$ & 0 & 0.0 & 0 & 0.0 \\
\hline $1.54-3.07$ & 3 & 14.3 & 8,400 & 39.5 \\
\hline $0.768-1.54$ & 6 & 42.9 & 8,000 & 77.2 \\
\hline $0.384-0.768$ & 6 & 71.4 & 3,050 & 91.5 \\
\hline $0.192-0.384$ & 6 & 100.0 & 1,800 & 100.0 \\
\hline $0.096-0.192$ & 0 & 100.0 & 0 & 100.0 \\
\hline $0.048-0.096$ & 0 & 100.0 & 0 & 100.0 \\
\hline Total & 21 & & 21,250 & \\
\hline
\end{tabular}


Table A1-2. Distribution of gas by field size category for stranded gas in gas fields in Iran, Iraq, Saudi Arabia, the United Arab Emirates, Oman, and Yemen.-Continued

[Field data current through the end of 2008 are from IHS Inc. (2009). Country totals here differ slightly from those in table A1-1 because the minimum field size in this table is 0.048 TCF. Israel, Syria, Kuwait, and Qatar are not included in this table because the volumes of stranded gas reported are small relative to domestic demand, and so exports are unlikely. TCF, trillions of cubic feet; BCF, billions of cubic feet]

\begin{tabular}{|c|c|c|c|c|}
\hline $\begin{array}{l}\text { Gas field size } \\
\text { class range } \\
\text { (TCF) }\end{array}$ & Number of fields & $\begin{array}{l}\text { Cumulative } \\
\text { percentage of } \\
\text { fields }\end{array}$ & $\begin{array}{l}\text { Volume in size } \\
\text { class } \\
\text { (BCF) }\end{array}$ & $\begin{array}{c}\text { Cumulative } \\
\text { percentage of gas } \\
\text { volume }\end{array}$ \\
\hline \multicolumn{5}{|c|}{ United Arab Emirates } \\
\hline$>49.2$ & 0 & 0.0 & 0 & 0.0 \\
\hline $24.6-49.2$ & 0 & 0.0 & 0 & 0.0 \\
\hline $12.3-24.6$ & 0 & 0.0 & 0 & 0.0 \\
\hline $6.14-12.3$ & 0 & 0.0 & 0 & 0.0 \\
\hline $3.07-6.14$ & 1 & 9.1 & 4,200 & 41.6 \\
\hline $1.54-3.07$ & 1 & 18.2 & 2,000 & 61.5 \\
\hline $0.768-1.54$ & 2 & 36.4 & 1,994 & 81.2 \\
\hline $0.384-0.768$ & 1 & 45.5 & 400 & 85.2 \\
\hline $0.192-0.384$ & 5 & 90.9 & 1,389 & 99.0 \\
\hline $0.096-0.192$ & 1 & 100.0 & 105 & 100.0 \\
\hline $0.048-0.096$ & 0 & 100.0 & 0 & 100.0 \\
\hline Total & 11 & & 10,088 & \\
\hline \multicolumn{5}{|c|}{ Oman } \\
\hline$>49.2$ & 0 & 0.0 & 0 & 0.0 \\
\hline $24.6-49.2$ & 0 & 0.0 & 0 & 0.0 \\
\hline $12.3-24.6$ & 0 & 0.0 & 0 & 0.0 \\
\hline $6.14-12.3$ & 0 & 0.0 & 0 & 0.0 \\
\hline $3.07-6.14$ & 3 & 9.4 & 12,035 & 59.7 \\
\hline $1.54-3.07$ & 0 & 9.4 & 0 & 59.7 \\
\hline $0.768-1.54$ & 2 & 15.6 & 2,750 & 73.4 \\
\hline $0.384-0.768$ & 5 & 31.3 & 2,185 & 84.2 \\
\hline $0.192-0.384$ & 8 & 56.3 & 1,816 & 93.2 \\
\hline $0.096-0.192$ & 7 & 78.1 & 931 & 97.9 \\
\hline $0.048-0.096$ & 7 & 100.0 & 431 & 100.0 \\
\hline Total & 32 & & 20,148 & \\
\hline \multicolumn{5}{|c|}{ Yemen } \\
\hline$>49.2$ & 0 & 0.0 & 0 & 0.0 \\
\hline $24.6-49.2$ & 0 & 0.0 & 0 & 0.0 \\
\hline $12.3-24.6$ & 0 & 0.0 & 0 & 0.0 \\
\hline $6.14-12.3$ & 0 & 0.0 & 0 & 0.0 \\
\hline $3.07-6.14$ & 1 & 5.9 & 3,500 & 45.8 \\
\hline $1.54-3.07$ & 0 & 5.9 & 0 & 45.8 \\
\hline $0.768-1.54$ & 0 & 5.9 & 0 & 45.8 \\
\hline $0.384-0.768$ & 5 & 35.3 & 2,559 & 79.3 \\
\hline $0.192-0.384$ & 4 & 58.8 & 968 & 92.0 \\
\hline $0.096-0.192$ & 1 & 64.7 & 175 & 94.3 \\
\hline $0.048-0.096$ & 6 & 100.0 & 437 & 100.0 \\
\hline Total & 17 & & 7,639 & \\
\hline
\end{tabular}




\section{Appendix 2. Field Development, Production, and Transportation Cost Estimates}

The onshore and offshore field development and production cost estimation scheme is from Attanasi and Freeman (2011).

\section{Onshore Field Cost Estimation}

Capital and operating costs for a suite of model fields were computed at each size class and at all depth intervals for countries having stranded gas by using QUE\$TOR software (IHS Inc., 2008). The model field is a regarded as the representative field within each size class. The QUE\$TOR software cost estimates were country and basin specific and also took into account terrain, climate, and typical capital equipment procurement strategies. Cost estimates included capital and operating costs of wells, processing facilities, and required supporting infrastructure. Processing facilities to remove natural gas liquids (NGLs) from the gas stream were also included in the model field equipment configurations, so that the separate gas and liquids pipelines may transport these products to their respective markets. Basic onshore field design specifications that represented the model gas fields are presented in table A2-1. In the absence of detailed field plans, numerous simplifying assumptions were made in the preparation of costs. The QUE\$TOR software (IHS Inc., 2008) selected the equipment sizes and equipment configurations given a design concept based on the number of wells and the assumed field production profiles. The QUE\$TOR software also allowed specification and added costs of ancillary infrastructure required for field development in areas with little infrastructure.

\section{Offshore Field Cost Estimation}

The cost analysis for offshore fields required several phases. First, the QUE\$TOR software (IHS Inc., 2008) was applied to assemble a cost database for gas field configurations characteristic of the U.S. Gulf of Mexico for each field size class and water depth category where gas has been found. Cost items included capital and operating costs for wells, platforms, and support facilities. A similar cost database was assembled for at least two model fields in different size classes and encompassing the water depth classes at each study location (country and province) where the stranded gas field costs were to be estimated. Then country and province cost indices were constructed by comparing cost estimates for the two size classes analyzed for each depth category in the Gulf of Mexico to corresponding costs for each study area. The indices were then used to estimate the study area's costs of the other representative gas field size classes not examined by using the Gulf of Mexico costs as the benchmark. For offshore fields, it was assumed that produced gas and liquids were brought onshore to a coastal transshipment location where the gas enters an international pipeline or it is liquefied as LNG and then shipped by seagoing tanker to market. Field design specifications and development concepts for offshore fields are summarized in appendix table A2-2.

\section{Transportation of Gas to Market}

Clusters of stranded gas fields were assembled on the basis of the spatial distribution or location of the fields to support the cost of the hypothetical gas transportation infrastructure. A hub was located to minimize the sum of the costs of transporting the gas from field feeder lines to the hub and the cost of larger pipe from the hub to a terminus. The unit cost (per MCF) for transportation declines dramatically with increases in the volume of gas transported, and so the hubs were centrally located among the fields served to maximize the more efficient trunk line distance.

Daily flow rates of the feeder lines (field to hub) were based on the plateau production rate of the representative field for the field size class. The nominal flow rate of the trunk line was based on the daily flow rate that would deliver the total volume of gas in the fields serviced by the hub to a transshipment location during a 25-year period. This procedure was used for both onshore and offshore stranded gas fields. In cases where onshore pipeline infrastructure to the transshipment location already exists, it was assumed that the original pipeline right-of-way was sufficiently large to allow a parallel regional structure to service the stranded gas. The development of the stranded gas fields must bear the full cost of the new parallel line. Pipeline transportation facilities were assumed to be operated as regulated carriers. Tariffs are set to recover operating costs and invested capital, plus a 12-percent after-tax return on capital. A 50-percent net income tax rate was assumed. Invested capital is recovered through depreciation.

Gas collected from fields into the designated hubs was transported to larger regional pipelines that terminate either at an LNG plant on a coast or at the right-of-way of an international gas pipeline. The transport costs for computing delivery costs by pipelines to specific markets also were based on the assumption that newly constructed dedicated pipelines would be constructed along existing rights-of-way. When pipeline distances of existing lines were not available, distances were estimated by using geographic information system (GIS) tools. For hypothetical pipelines, pipeline distances were estimated by using the GIS tools applied to the posited routes in a piecewise linear fashion. For these routes, the calculated distance was increased by 30 percent to compensate for natural topography and the costs of creating a new right-of-way where bridges or tunnel construction would be required. Hypothetical pipelines were posited from Proskokovo, Russia, to China's Second West-East pipeline and from field clusters in eastern Siberia to Beijing and to Vladivostok, Russia (fig. 11). 
Table A2-1. Prototype model designs for onshore gas field development.

[BCF, billions of cubic feet; $\mathrm{MMCF} / \mathrm{D}$, millions of cubic feet per day]

\begin{tabular}{rccccc}
\hline Size class & $\begin{array}{c}\text { Reserves } \\
\text { (BCF) }\end{array}$ & $\begin{array}{c}\text { Field life } \\
\text { (years) }\end{array}$ & $\begin{array}{c}\text { Number of } \\
\text { wells }\end{array}$ & $\begin{array}{c}\text { Reserves per } \\
\text { well } \\
\text { (BCF) }\end{array}$ & $\begin{array}{c}\text { Plateau } \\
\text { flow rate } \\
\text { (MMCF/D) }\end{array}$ \\
\hline 9 & 68 & 17 & 10 & 6.8 & 13.6 \\
10 & 136 & 17 & 13 & 10.5 & 27.2 \\
11 & 272 & 17 & 19 & 14.3 & 54.4 \\
12 & 543 & 25 & 28 & 19.4 & 101 \\
13 & 1,086 & 23 & 41 & 26.5 & 201 \\
14 & 2,172 & 22 & 62 & 35.0 & 403 \\
\hline
\end{tabular}

Table A2-2. Prototype model designs for offshore gas field development.

[BCF, billions of cubic feet; MMCF/D, millions of cubic feet per day; ft, feet]

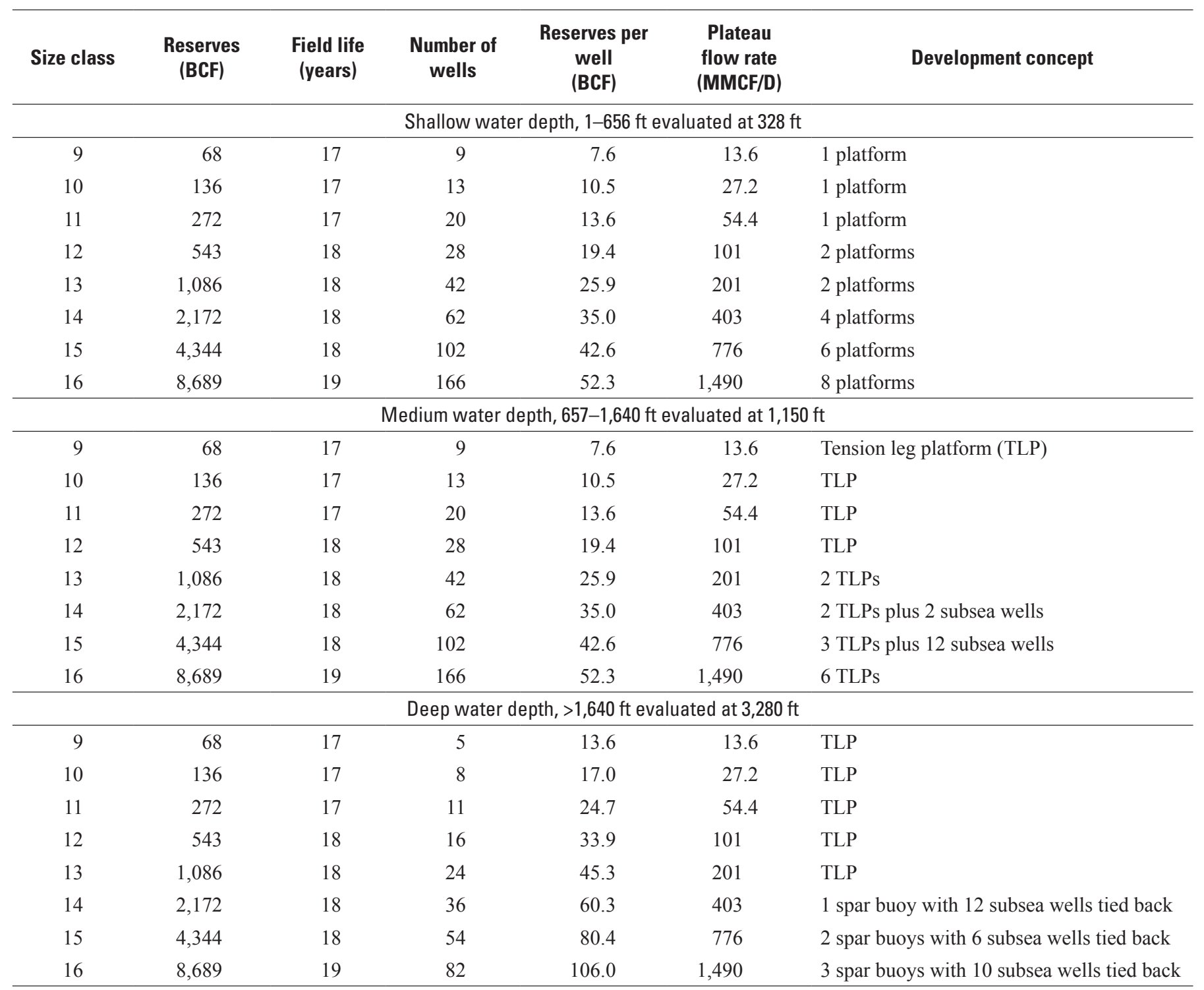




\section{Appendix 3. Estimation of Liquefaction Cost and the Transportation Costs of Liquefied Natural Gas}

\section{Liquefaction Plant Complex}

The sizes of plants that liquefy natural gas are commonly expressed in terms of millions of metric tons of liquefied natural gas that can be produced annually based on 350 days of annual operation. An LNG complex consists of the plant made up of process trains that purify and liquefy the gas, storage facilities, and docking facilities for loading seagoing LNG tankers. Process components of a plant condition or purify the gas and then liquefy the gas by cooling. New, or greenfield, plants are more costly to construct and operate than the equivalent capacity expansions of operating plants accomplished by adding process trains. Storage and docking facilities costs do not increase proportionately with the addition of another process train.

For new plants or plants where trains are added, gas liquefaction cost computations depend on the estimates of the capital or investment cost per metric ton of annual output capacity. According to Durr and others (2005), plants and single-process trains exhibit similar economies of scale. The data published by Durr and others (2005) were used to fit a generic scale and cost relationship that approximated the six-tenths rule. ${ }^{1}$ A new plant complex with a single train having a capacity of 6 million metric tons per year (MTY) constructed in Australia (or North America or Russia, for that matter) was assumed to have a capital cost of 1,025 U.S. dollars per metric ton (USD/t) of LNG output. The addition of a 6-MTY train with additional storage and dock facilities cost $850 \mathrm{USD} / \mathrm{t}$ of LNG output. Construction costs for plants and additional trains in Indonesia and Malaysia were 850 and $700 \mathrm{USD} / \mathrm{t}$ of LNG, respectively, and the cost of refurbishing idle facilities was $500 \mathrm{USD} / \mathrm{t}$ of LNG output. For smaller scale facilities, the cost per metric ton increased according to the fitted function from the data in Durr and others (2005).

The cost of liquefaction per MMBtu of plant output was calculated on the basis of a cost-of-service procedure. Annual operating cost (excluding feed gas) was assumed to be 4 percent of investment cost (Energy and Environmental Analysis, Inc., 1988), plant life was 25 years, a 12-percent rate of return was required, and a net income tax rate of 50 percent was assumed with capital recovered from depreciation allowance. Transformation of input gas to output gas was also assumed to be 85 percent efficient (Energy and Environmental Analysis, Inc., 1988). It was assumed that all gas liquids would be removed at the field level and sold by the operators so that the LNG plant would use dry gas, principally methane.

\section{Shipping Costs for Liquefied Natural Gas}

Distances from the LNG plants to market ports were first calculated (see table A3-1). It was assumed that the LNG tanker would have a sailing speed of 18 knots, a ship life of 20 years, a capacity of 140,000 cubic meters, and an initial cost of $\$ 270$ million. It was also assumed the ship would be powered by boiloff LNG gas. Daily boiloff was assumed be equivalent to 0.125 percent of the ship's cargo capacity. The number of days per trip was calculated as the number of sailing days between ports assuming a speed of 18 knots and a 3-day allowance per round trip for loading and unloading cargo. Tankers were assumed to operate 330 days per year. Insurance and maintenance were 1.3 percent and 1 percent of the ship's value, respectively. Total annual operating cost included insurance, maintenance, consumables, labor, and overhead, which was assumed to be 4.1 percent of the ship's value (Energy and Environmental Analysis, Inc., 1988). Tariff rates were set to repay operation costs, pay taxes, recover investment through depreciation, and provide a 12-percent after-tax rate of return on the investment. A 50-percent net income tax rate was assumed.

\section{Existing and Potential Capacity for Liquefied Natural Gas Production}

Table A3-2 shows the existing LNG capacity for plants in Southeast Asia and Oceania and Russia, the Middle East, Africa, and South America. The Southeast Asia and Oceania region accounts for about 32 percent of the total of 279 MTY of LNG capacity represented in this table. The Middle East and Africa account for 33 percent and 25 percent, respectively, of the total LNG capacity shown. Table A3-3 shows the additional capacity of LNG plants under construction in the Southeast Asia and Oceania region. This includes 69.5 MTY for Australia, 6.6 MTY for Papua New Guinea, and 2.0 MTY for Indonesia.

\footnotetext{
${ }^{1}$ If the scale of the reference plant is $\mathrm{S}_{\mathrm{r}}$ with reference $\operatorname{cost} \mathrm{C}_{\mathrm{r}}$ and if $\mathrm{S}_{\mathrm{p}}$ is the scale of a projected plant, the application of the six-tenths rule estimates the project cost, $\mathrm{C}_{\mathrm{p}}$, as $\mathrm{C}_{\mathrm{p}}=\mathrm{C}_{\mathrm{r}}\left(\mathrm{S}_{\mathrm{r}} / \mathrm{S}_{\mathrm{p}}\right)^{0.6}$.
} 
Table A3-1. Estimated costs of transporting liquefied natural gas (LNG) from LNG complex to destination regasification facility and market.

[For comparisons, the distance from Withnell Bay, Australia, to South Hook, UK, is 11,090 nmi. \$/MMBtu, dollars per million British thermal units in constant 2008 dollars; nmi, nautical miles]

\begin{tabular}{|c|c|c|c|c|c|}
\hline $\begin{array}{l}\text { LNG complex } \\
\text { (figs. } 6,7,11 \text { ) }\end{array}$ & Source location & \multicolumn{2}{|c|}{ Yokohama, Japan } & \multicolumn{2}{|c|}{ Shanghai, China } \\
\hline Withnell Bay & Pilbara, Western Australia & 3,850 & 1.65 & 3,565 & 1.54 \\
\hline Browse (proposed) & Kimberly, Western Australia & 3,470 & 1.52 & 3,185 & 1.41 \\
\hline Bintulu & Sarawak, Malaysia & 2,470 & 1.11 & 1,850 & 0.88 \\
\hline Blang Lancang & Arun, Sumatra, Indonesia & 3,371 & 1.48 & 2,689 & 1.20 \\
\hline Tangguh & Irian Jaya, Indonesia & 2,480 & 1.12 & 2,200 & 1.01 \\
\hline Donggi-Senoro & Sulawesi, Indonesia & 2,460 & 1.13 & 2,120 & 1.00 \\
\hline \multirow[b]{2}{*}{$\begin{array}{l}\text { LNG complex } \\
\text { (figs. } 6,7,11 \text { ) }\end{array}$} & \multirow[b]{2}{*}{ Source location } & \multicolumn{2}{|c|}{ Incheon, South Korea } & \multicolumn{2}{|c|}{ Hazira, India } \\
\hline & & $\begin{array}{c}\text { Distance } \\
\text { (nmi) }\end{array}$ & $\begin{array}{c}\text { Transport cost } \\
\text { (\$/MMBtu) }\end{array}$ & $\begin{array}{c}\text { Distance } \\
\text { (nmi) }\end{array}$ & $\begin{array}{l}\text { Transport cost } \\
\text { (\$/MMBtu) }\end{array}$ \\
\hline Withnell Bay & Pilbara, Western Australia & 4,001 & 1.71 & 3,691 & 1.59 \\
\hline Browse (proposed) & Kimberly, Western Australia & 3,621 & 1.58 & 3,925 & 1.70 \\
\hline Darwin & Darwin, Australia & 3,315 & 1.46 & 4,320 & 1.85 \\
\hline Gladstone & Queensland, Australia & 4,519 & 1.94 & 5,953 & 2.51 \\
\hline
\end{tabular}


Table A3-2. Existing LNG capacity outside North America.

[Data are from True (2012) except that Middle East data are from the International Group of Liquefied Natural Gas Importers (2011). BCF/D, billions of cubic feet per day; LNG, liquefied natural gas; MTY, millions of metric tons per year; T1, train 1; 350 working days in a year. Numbers may not add up due to rounding]

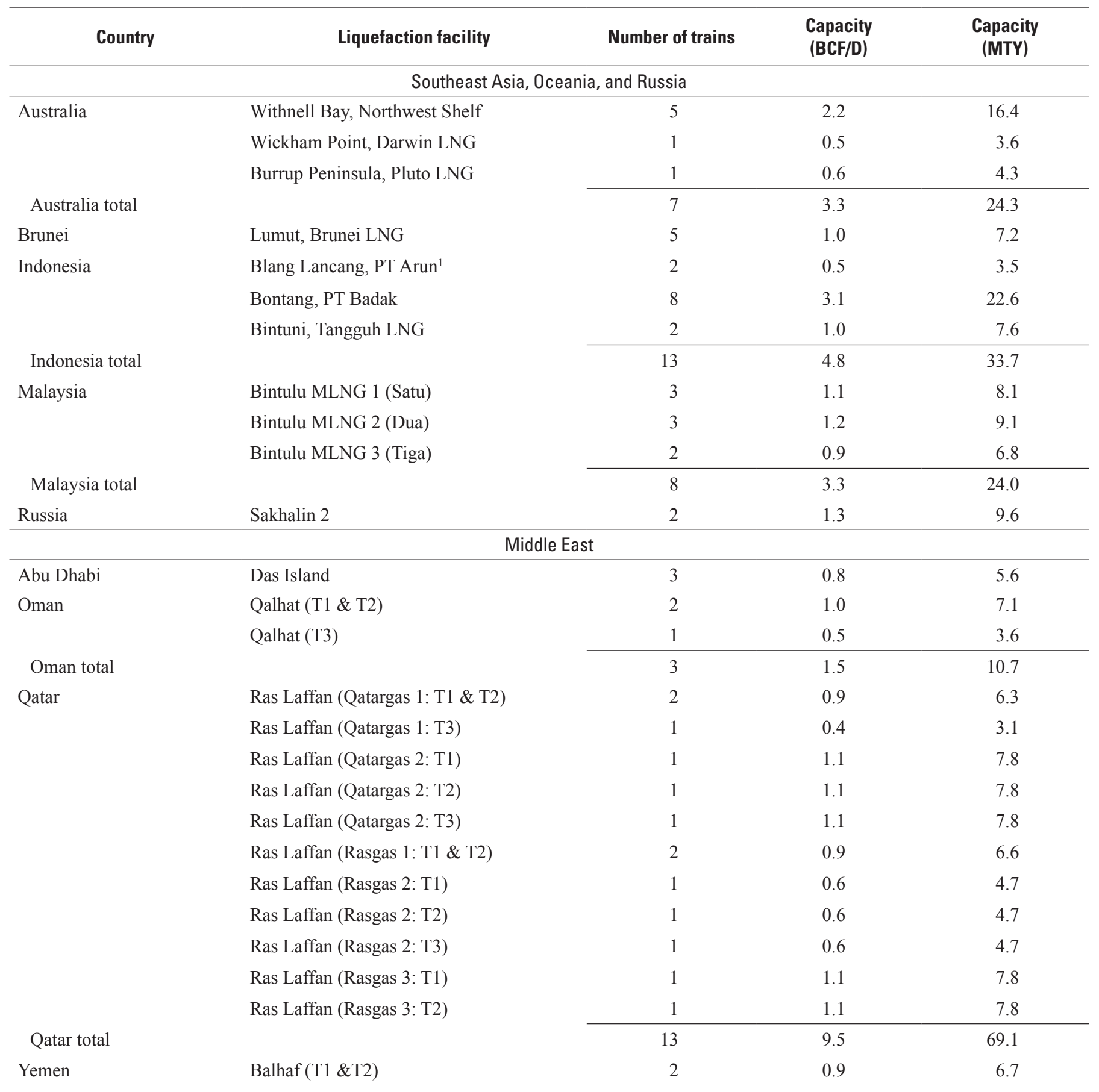


Table A3-2. Existing LNG capacity outside North America.-Continued

[Data are from True (2012) except that Middle East data are from the International Group of Liquefied Natural Gas Importers (2011). BCF/D, billions of cubic feet per day; LNG, liquefied natural gas; MTY, millions of metric tons per year; T1, train 1; 350 working days in a year. Numbers may not add up due to rounding]

\begin{tabular}{|c|c|c|c|c|}
\hline Country & Liquefaction facility & Number of trains & $\begin{array}{c}\text { Capacity } \\
\text { (BCF/D) }\end{array}$ & $\begin{array}{c}\text { Capacity } \\
\text { (MTY) }\end{array}$ \\
\hline \multicolumn{5}{|c|}{ Africa } \\
\hline \multirow{3}{*}{ Algeria } & Arzew (GL2Z) & 6 & 1.2 & 8.4 \\
\hline & Arzew (GL3Z) & 1 & 0.6 & 4.7 \\
\hline & Skida (GL1K, GL2K) & 3 & 0.5 & 3.5 \\
\hline Algeria total & & 19 & 3.5 & 25.5 \\
\hline Libya & Marsa-el-Braga & 3 & 0.1 & 0.6 \\
\hline \multirow[t]{2}{*}{ Egypt } & Damietta & 1 & 0.7 & 4.8 \\
\hline & Idku & 2 & 1.0 & 7.2 \\
\hline \multirow{2}{*}{ Nigeria } & Bonny Island (T4, T5) & 2 & 1.1 & 8.2 \\
\hline & Bonny Island (T6) & 1 & 0.6 & 4.1 \\
\hline Nigeria total & & 6 & 3.0 & 22.2 \\
\hline Equatorial Guinea & Bioko Island & 1 & 0.5 & 3.4 \\
\hline Angola & Soyo & 1 & 0.7 & 5.2 \\
\hline \multicolumn{5}{|c|}{ South America } \\
\hline Trinidad \& Tobago & Point Fortin & 4 & 2.1 & 15.1 \\
\hline Peru & Melchorita & 1 & 0.6 & 4.4 \\
\hline
\end{tabular}

${ }^{1}$ Four additional trains are mothballed.

Table A3-3. LNG capacity under construction accessible to Asian importers from Southeast Asia and Oceania.

[Data are from True (2012) except that Browse data are from Woodside Energy (2012). BCF/D, billions of cubic feet per day; LNG, liquefied natural gas; MTY, millions of metric tons per year; TBD, to be determined; 350 working days in a year. Numbers may not add up due to rounding]

\begin{tabular}{|c|c|c|c|c|}
\hline Country & $\begin{array}{l}\text { Liquefaction facility } \\
\text { (start-up year) }\end{array}$ & $\begin{array}{l}\text { Number of } \\
\text { trains }\end{array}$ & $\begin{array}{l}\text { Capacity } \\
\text { (BCF/D) }\end{array}$ & $\begin{array}{c}\text { Capacity } \\
\text { (MTY) }\end{array}$ \\
\hline \multirow[t]{8}{*}{ Australia } & Burrup Peninsula, Pluto LNG (2013) & 1 & 0.6 & 4.3 \\
\hline & Burrup Peninsula, Pluto LNG (2014) & 1 & 0.6 & 4.3 \\
\hline & Barrow Island, Gorgon LNG (2014) & 3 & 2.1 & 15.0 \\
\hline & Gladstone, Queensland Curtis LNG (2014) & 2 & 1.2 & 8.5 \\
\hline & Gladstone LNG (2015) & 2 & 1.1 & 7.8 \\
\hline & Gladstone, Australia Pacific LNG (2015-16) & 2 & 1.2 & 9.0 \\
\hline & Ashburton North, Wheatstone LNG (2016) & 2 & 1.2 & 8.6 \\
\hline & Kimberly Coast, Browse (year TBD) & 3 & 1.6 & 12.0 \\
\hline Australia total & & 16 & 9.5 & 69.5 \\
\hline Indonesia & Donggi-Senoro (2014) & 1 & 0.3 & 2.0 \\
\hline Papua New Guinea & Port Moresby (2014) & 1 & 0.9 & 6.6 \\
\hline
\end{tabular}




\section{Appendix 4. Countries in Each Region}

This report refers to regions for which data on stranded gas were provided in figure 1 and tables $1-4$. Table A4-1 lists the countries in each region where some stranded gas has been reported and summarized in figure 1 and tables 1 and 2.

Table A4-1. List of countries reporting stranded gas in gas fields by regions as used in figure 1 and tables 1, 2, 3, and 4 .

[Asterisk indicates presence of offshore fields. Field data through the end of 2008 are from IHS Inc. (2009)]

\begin{tabular}{|c|c|}
\hline Region & Countries \\
\hline South America ${ }^{1}$ & $\begin{array}{l}\text { Argentina*, Barbados, Bolivia, Brazil*, Chile*, Colombia*, Guatemala, Paraguay, Peru*, Trinidad } \\
\text { and Tobago*, and Venezuela*. }\end{array}$ \\
\hline Africa & $\begin{array}{l}\text { Algeria, Angola*, Cameroon*, Chad, Congo*, Cote d'Ivoire*, Egypt*, Equatorial Guinea*, Eritrea*, } \\
\text { Ethiopia, Gabon*, Ghana*, Libya*, Madagascar*, Mauritania*, Morocco, Mozambique*, } \\
\text { Namibia*, Nigeria*, Senegal, Somalia, South Africa*, Sudan*, Tanzania*, and Tunisia*. }\end{array}$ \\
\hline South Asia & Afghanistan, Bangladesh*, India*, and Pakistan*. \\
\hline Russia & Russia*. \\
\hline
\end{tabular}

${ }^{1}$ South America includes stranded gas fields in the Caribbean and Central America except Mexico.

${ }^{2} \mathrm{Svalbard}$ is a territory of Norway.

${ }^{3}$ New Caledonia is a special collectivity of France. 